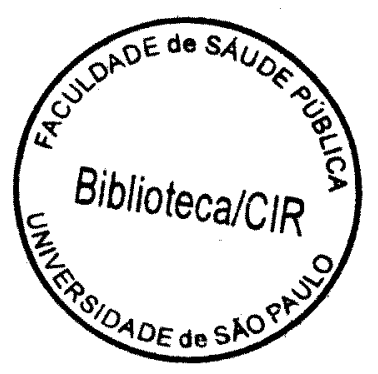

\title{
MERENDA ESCOLAR: HISTÓRIA, EVOLUÇÃO E CONTRIBUIÇÃO NO ATENDIMENTO DAS NECESSIDADES NUTRICIONAIS DA CRIANÇA
}

\begin{abstract}
Tese apresentada ao Departamento de Nutrição da Faculdade de Saúde Pública da Universidade de São Paulo para obtenção do Título de Doutor em Saúde Pública.
\end{abstract}

Orientador: PROF.DR. SOPHIA CORNBLUTH SZARFARC 


\section{Stefanini, Maria Lucia Rosa}

Merenda escolar: história, evolução e contribuição no atendimento das necessidades nutricionais da criança - São Paulo, 1998.

-p. 164

Tese (Doutorado em Saúde Pública). Faculdade de Saúde Pública da Universidade de São Paulo.

1. Programa de merenda escolar. 2. Anemia ferropriva. 3. Escolar 4. Avaliação de política pública.

$$
3743498 \text { doe }
$$


"Eu sustento que a única finalidade da ciência está em aliviar a miséria da existência humana"

Bertold Brecht 
Aos meus pais

Helena e Gesuldo (in memorian) 
Ao Edson

companheiro de todos os momentos e aos filhos maravilhosos

André, Renato e Francisco

pelo amor, incentivo e tolerância 
À Eliete Salomon Tudisco (in memorian)

de quem tive a felicidade de ser amiga desde nosso curso de graduação;

com quem tive o privilégio de compartilhar experiências carregadas das incertezas dos primeiros anos de vida profissional;

a quem devo respeito e admiração pela brilhante carreira pautada na defesa de valores éticos e morais. 


\section{AGRADECIMENTOS}

À Professora Doutora Sophia Cornbluth Szarfarc, pela orientação competente, carinhosa e tolerante e por acreditar na possibilidade da realização deste trabalho.

Ao Professor Doutor José da Rocha Carvalheiro, Diretor do Instituto de Saúde, pelo estímulo permanente ao aprimoramento da formação de todos os pesquisadores do Instituto, pelo apoio à realização deste projeto e pelo carinho e amizade sempre presentes.

Ao Professor Doutor Odécio Sanches, que gentilmente desenhou e executou o plano de amostragem e me orientou nas estimativas da prevalência de anemia.

À Eliete Cândida de Lima Cortez, Diretora do Núcleo de Informática do Instituto de Saúde, pelo apoio logístico que viabilizou a execução deste trabalho, e pela amizade e apoio profissional.

À Ausônia Favorido Donato, amiga e orientadora psico-pedagógica, que fez a primeira revisão de português.

Às colegas pesquisadoras e companheiras do Núcleo de Nutrição do Instituto de Saúde, Barbara Regina Lerner, Doris Lucia Martini Lei, Marly Augusto Cardoso e Sandra Pinheiro Chaves, pelo apoio e amizade.

À Carmem Campos Arias Paulenas e Maria Aparecida Esteves, bibliotecárias do Instituto de Saúde, pela orientação e revisão bibliográficas.

À Vera Lúcia Gattás, Tereza Etsuko Rosa, Maria Mercedes Escuder, Pesquisadoras Científicas do Instituto de Saúde, pelo apoio e colaboração na utilização dos pacotes estatísticos. 
À Rosita José da Silva, Técnica de Apoio à Pesquisa Científica do Instituto de Saúde, que realizou com carinho, responsabilidade e competência a digitação deste trabalho.

À Aparecida Natalia Rodrigues, Técnica de Apoio à Pesquisa Científica do Instituto de Saúde, pela amizade e responsabilidade na digitação das referências bibliográficas.

À Adriana Bouças Ribeiro, bolsista do CNPq, e à Simone Ribeiro Spinetti, aprimoranda da FUNDAP, que participaram do trabalho de campo, montagem do banco de dados e cálculo dos cardápios.

Ao Nelson Francisco Brandão, Assistente Técnico de Pesquisa do Instituto de Saúde, pela competente editoração deste trabalho.

À Tânia Sena de Souza, Técnica de Apoio à Pesquisa Científica do Instituto de Saúde, pela colaboração na digitação das tabelas.

À Sebastiana Rita dos Santos Maia e à Vânia Regina Postigo, secretárias da Diretoria do Instituto de Saúde, pela colaboração e paciência. 


\section{ÍNDICE}

\section{RESUMO}

SUMMARY

1 INTRODUÇÃO 1

2 OBJETIVOS

3 METODOLOGIA

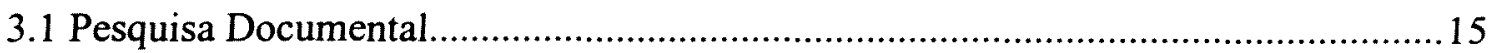

3.2 Estudo da Composição da Merenda Escolar ............................................................15

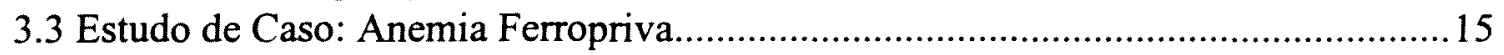

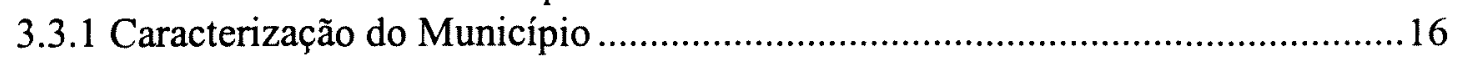

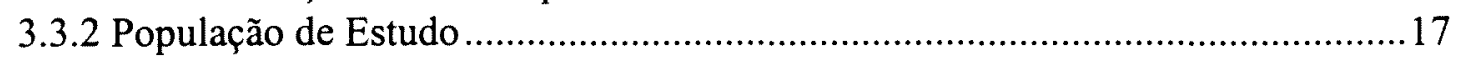

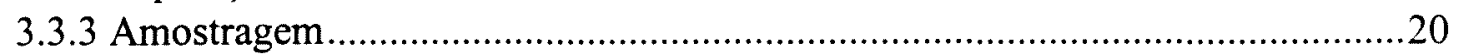

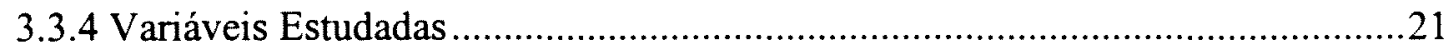

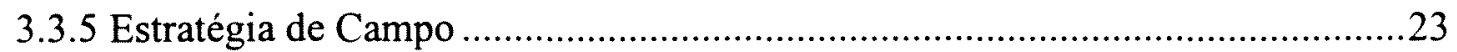

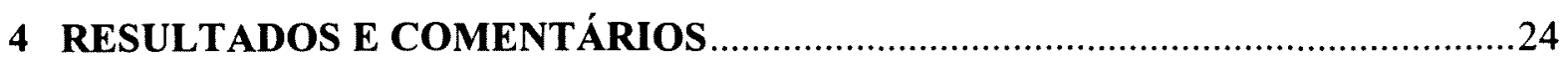

4.1 Reconstituição da Trajetória do Programa de Merenda Escolar...................................26

4.1.1 Introdução às Políticas de Alimentação em nível internacional ........................26

4.1.2 Política de Alimentação e Nutrição no Brasil e o PME........................................35

4.2 Estudo de Caso: Anemia Ferropriva e Programa de Merenda Escolar.........................64

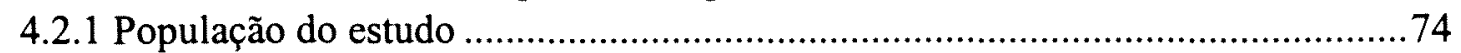

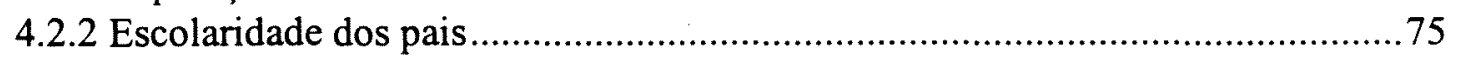

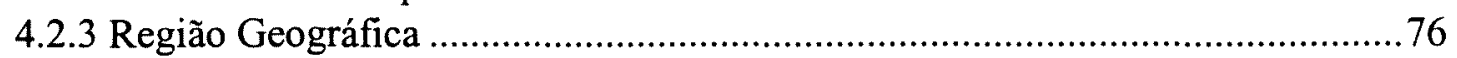

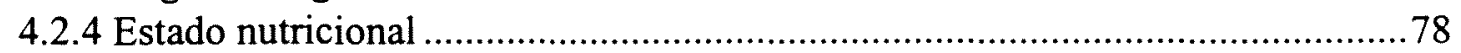

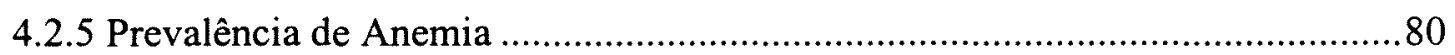

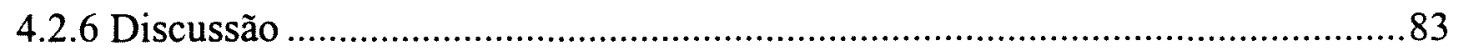

5 CONSIDERAÇÕES FINAIS

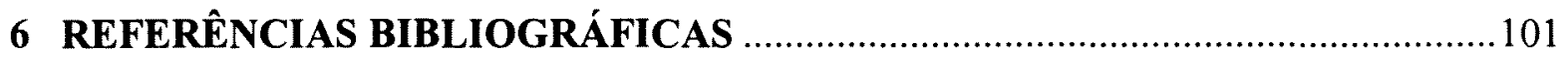

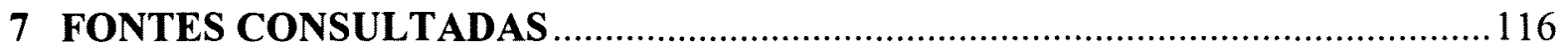

8 ANEXOS

Anexo I. Instrumento Utilizado no Estudo de Caso para Obtenção de Informações

Anexo II. Decreto $n^{\circ} 37106$ de 31/3/1955 que Institui a Campanha de Merenda

Escolar e Portaria 388 de 22/11/57 sobre Regimento

Anexo III. Composição de cardápios do Programa de Merenda Escolar

Anexo IV. Composição da merenda escolar do município de Santos

Anexo V. Siglas utilizadas no texto e seus significados 


\section{R E S U M O}

\section{MERENDA ESCOLAR: HISTÓRIA, TENDÊNCIAS E CONTRIBUIÇÃO NO ATENDIMENTO DAS NECESSIDADES NUTRICIONAIS DA CRIANÇA}

No Brasil, a merenda escolar sempre esteve presente nos programas de suplementação alimentar. As primeiras iniciativas datam da década de 30, quando alguns estados e municípios mais ricos passaram a responsabilizar-se, de forma crescente, pelo fornecimento da merenda em suas redes de ensino. Nos anos 50, criou-se o Programa Nacional de Alimentação Escolar. Desde então, o Programa de Merenda Escolar manteve o objetivo de contribuir para melhorar as condições nutricionais e de saúde dos escolares, ao fornecer alimentação suplementar. Na definição de sua composição nutritiva, estabeleceuse que deveria fornecer de $15 \%$ a $30 \%$ das recomendações de calorias e nutrientes.

Este estudo teve por objetivo reconstituir a evolução histórica do Programa de Merenda Escolar no Brasil, como uma política pública aplicada no decorrer dos últimos cinqüenta anos, e avaliar sua capacidade potencial no atendimento de necessidades nutricionais específicas dos escolares.

A metodologia dividiu-se em três partes: pesquisa documental, estudo da composição da merenda escolar e estudo de caso para caracterizar uma carência nutricional específica. Tomou-se como modelo a deficiência de ferro, por ser apontada, com freqüência, como um problema de saúde pública muito presente na população estudada.

Foi realizado um estudo de prevalência de anemia em amostra representativa de escolares das $1^{\text {as }}, 5^{\text {as }}$ e $8^{\text {as }}$ séries das escolas públicas do município de Santos; verificou-se 
também, a composição da merenda escolar oferecida quanto às quantidades de alimentos e nutrientes.

As prevalências de anemia foram estimadas em $27,81 \%$ para os escolares das $1^{\text {as }}$ séries, $11,31 \%$ para os de $5^{\text {as }}$ séries e $5,61 \%$ para os de $8^{\text {as }}$ séries. Houve diferenças estatisticamente significantes entre anemia e escolaridade do pai e entre anemia e região geográfica. O estudo da composição da merenda escolar mostrou que a presença do ferro, nas quantidades recomendadas pelo programa, é muito pouco freqüente.

Com esses resultados, considerando a importância e a dimensão do Programa de Merenda Escolar e, ainda, o seu processo de descentralização e municipalização que se concretiza, toma-se necessário repensar os seus objetivos nutricionais e o seu alcance social. 


\section{S U M M A R Y}

\section{SCHOOL LUNCH PROGRAM IN BRAZIL: HISTORY, TRENDS AND CONTRIBUTION TO THE RECOMMENDED DIETARY ALLOWANCES OF SCHOOLCHILDREN}

In Brazil, the school lunch has always been present in the food suplemmentation programs. The first attempts were carried out in the 1930's, when some Brazilian rich states and counties assumed the responsability of school lunch distribution through the public schools. In the 1950 's, The National School Lunch Program was created. Since then, The School Lunch Program was maintained to improve the nutritional and health conditions of schoolchildren. Lunches served to schoolchildren should provide about onethird of the Recommended Dietary Allowances.

The purpose of this study is to describe the historical background of the Brazilian National School Lunch Program, as a public issue implemented in the last 50th years, and to assess its efficacy in improving nutritional status of schoolchildren.

The methodology was divided in three parts: documentary research, composition of school lunch, and case report of a specific nutritional deficiency. Iron deficiency was investigated because it is a common public health problem of our study population.

A representative schoolchildren sample of 1 st, 5th and 8 th grades from public schools, located in the county of Santos, State of São Paulo, was used to estimate the prevalence of anaemia. The composition and nutritional adequacy of school lunch was also investigated. Anaemia (haemoglobin concentrations below the cut-off values proposed by 
the World Health Organization) was diagnosed in $27.81 \%, 11.3 \%$ and $5.6 \%$ of the schoolchildren from 1 st, 5th and 8th grades, respectively.

There were statistical significant differences among anaemia, father's educational level, geographical area.

Taking into account the importance of The School Lunch Program and its process of decentralization and municipalization, it is necessary to think over its nutritional and social goals. 


\section{INTRODUÇÃO}


Os últimos cinqüenta anos apresentaram uma tendência mundial, sem precedentes, do aperfeiçoamento da saúde comunitária. Entretanto, esse avanço não foi uniforme no interior das comunidades ou nas várias partes do mundo.

Países desenvolvidos como Estados Unidos, Grã Bretanha e outras nações da Europa Ocidental, onde aumentou a esperança de vida ao nascer, enfrentam desafios de saúde relacionados as idades mais avançadas como controle das doenças crônicodegenerativas-câncer, enfermidades cardiovasculares e renais e músculo-esqueléticos, artrite e alterações mentais associadas à velhice. Os horizontes da saúde pública ainda se ampliam para a atuação na prevenção de acidentes, saúde mental e controle do meio ambiente.

Entretanto, grande grupo de países subdesenvolvidos no sentido econômico e tecnológico, ainda não resolveu problemas como controle de doenças infecciosas, abastecimento de água e de esgoto, apresentando condições de vida e de saúde muito distantes do nível minimamente aceitável (ROSEN, 1994).

Segundo OMRAN (1971), os países mais desenvolvidos ultrapassaram os três estágios sucessivos que compõem a transição epidemiológica: a "Era da pestilência e da fome" com altas taxas de mortalidade e baixa expectativa de vida; a "Era do declínio das pandemias" com queda gradativa da mortalidade, aumento da expectativa de vida e grande crescimento populacional e o terceiro, a "Era das doenças degenerativas e causadas pelo homem", quando a mortalidade continua a declinar e alcançar níveis relativamente baixos, a expectativa de vida aumenta e a fertilidade passa a ser o principal fator no crescimento da população. A esse modelo OLSHANSKY e AULT (1986), citados por CASTRO (1995), sugerem um quarto estágio: a "Era do retardamento das doenças degenerativas" na qual há 
queda da mortalidade nas idades mais avançadas por retardamento de mortes por doenças crônicas, ficando a expectativa de vida acima de 80 anos.

O Brasil se caracteriza pela presença dos dois extremos de preocupação, evidenciando de forma profunda as desigualdades sociais e de qualidade de vida existentes. Sua transição epidemiológica vem sendo marcada pela coexistência de distintos padrões de mortalidade e morbidade, com aumento crescente das doenças cardiovasculares, neoplasias e causas externas, ao lado de prevalências relevantes de doenças infecciosas. Esse perfil se enquadra no modelo polarizado prolongado, proposto por FRENK e col. (1991), que tem como característica principal essa situação prolongada retratada por um perfil de mortalidade e morbidade mista em diferentes regiões geográficas e grupos sociais. Tem se observado no país, nas últimas décadas, o aparecimento crescente, principalmente nos grandes centros urbanos, de agravos de saúde característicos de países desenvolvidos, proporcionando mudanças significativas do quadro epidemiológico da população. Entretanto, enfrenta problemas de países subdesenvolvidos, como por exemplo, os agravos nutricionais, caracterizados por carências alimentares, que estão muito presentes.

Pode-se dizer que o estado nutricional da população reflete o atendimento das necessidades do ser humano que incluem não só a disponibilidade e o acesso aos alimentos, como a diversificação e adequação nutricional da dieta, condições de saneamento, saúde e moradia. A situação alimentar e nutricional da população é exemplo dos mais ilustrativos das desigualdades existentes no nosso meio, A desnutrição energético-proteica representa, de fato, importante problema de saúde entre as crianças brasileiras menores de 5 anos, contribuindo para aumento do risco de morrer (PUFFER \& SERRANO, 1973; VICTORA e col, 1986). Agravos nutricionais precoces, repetidos e prolongados durante as fases criticas do crescimento e desenvolvimento deixam efeitos que 
se manifestam em atraso considerável de estatura, maturação defasada do esqueleto e do sistema nervoso central (SCRIMSHAW e col, 1970; WALTERLOW, 1978).

O crescimento físico do indivíduo constitui o resultado de características genéticas e de influência, do meio ambiente; entre essas influências a doença infecciosa e a ingestão de alimentos desempenham um papel de particular importância. A interação desses dois fatores na determinação do crescimento físico, está condicionada a elementos sociais e econômicos relacionados com a disponibilidade de alimentos, com o seu consumo e com as condições ambientais (SHRIMPTON, 1986). Josué de Castro, destacado médico e cientista social, escrevendo sobre os determinantes da fome mundial, já a considerava não como um problema de limites na produção, por força da natureza, mas sim, como simples problema de distribuição de tudo aquilo que o homem é capaz de produzir (CASTRO, 1939). O alimento não é apenas uma necessidade para a manutenção da vida, mas também uma mercadoria e está, portanto, indissoluvelmente ligado às formas de organização econômica (ROSEN, 1994).

As causas básicas da desnutrição se referem àquelas que explicam como os recursos potenciais de uma sociedade são mobilizados para a produção de bens e serviços e como são distribuídos. A produção, a distribuição e o consumo dos bens e serviços são determinados pela estrutura sócio-econômica da sociedade (JONSSON, 1981).

O acesso desigual aos bens produzidos, como a alimentação, os serviços de saúde, a educação, a habitação, os salários, determina o subdesenvolvimento da sociedade. Esse desequilíbrio na utilização dos bens de produção resulta na sistemática ingestão inadequada de nutrientes e na ausência em maior ou menor grau de saúde em grupos populacionais.

Os problemas relacionados com a desnutrição repercutem de forma direta e indireta sobre as condições de vida e de saúde da população. 
As pesquisas realizadas pelo $\operatorname{IBGE}^{*}$ e $\operatorname{INAN}^{* *}$ em 1974 e 1984, no âmbito nacional e que retratam o padrão de crescimento das crianças em dois momentos com intervalo de quinze anos $\left(\mathrm{ENDEF}^{* * *}\right.$ e $\left.\mathrm{PNSN}^{* * * *}\right)$, mostraram diminuição no que se refere a prevalência de desnutrição energético-proteica; apesar disto, o quadro evidenciado em 1989, mostrou-se distante do esperado quando são adequadas as condições de saúde e nutrição na infância e quando há acesso universal à alimentação e saúde, necessidades estas, elementares. A prevalência de déficits estaturais e ponderais na infância situava o Brasil junto a países em desenvolvimento cuja riqueza nacional, representada pelo $\mathrm{PIB}^{\square}$ per capita, correspondia à metade ou um terço da riqueza brasileira.

Apontava diferenças macro-regionais marcantes separando o Brasil em dois segmentos: Norte e Nordeste, com características semelhantes às nações pobres da África e América Central e o Sul, Sudeste e Centro-Oeste, a países de níveis altos ou médios de riqueza, com sistemas mais eficientes de seguridade social (FUNDAÇÃO IBGE/UNICEF, 1992; MONTEIRO e col, 1992, MONTEIRO, 1996). Assim, embora tenha havido melhoria no perfil de desenvolvimento estatural da população em relação ao encontrado na década de 70, o problema nutricional manteve-se grave e precoce: aos 5 meses de idade as crianças brasileiras já começavam a apresentar sinais visíveis de atraso no crescimento.

Além da desnutrição energético-protéica, apresentam posição de destaque no perfil epidemiológico nutricional dos brasileiros, as carências de nutrientes específicos sendo de maior relevância as de ferro, vitamina $\mathrm{A}$ e iodo, pela abrangência da população atingida ou pela gravidade e comprometimento que determinam. O ferro se destaca como aquele que mais nitidamente aparece como insuficiente. A anemia carencial, ligada à

\footnotetext{
- IBGE - Instituto Brasileiro de Geográfia e Estatística

* INAN - Instituto Nacional de Alimentação e Nutrição

*** ENDEF - Estudo Nacional de Despesa Familiar

**** PNSN - Pesquisa Nacional de Saúde e Nutrição

PIB - Produto Interno Bruto
} 
deficiência de ferro alimentar representa relevante problema nutricional de saúde coletiva, por se estender à considerável parcela da população nos diferentes estratos sociais e pelas implicações nos indicadores de saúde (INACG, 1978; OMS, 1968; OMS, 1975).Sua presença determina aumento do risco da prematuridade, de recém nascidos com baixo peso, reduz o rendimento do trabalho físico, diminui a resistência às agressões infecciosas e afeta o desenvolvimento comportamental, tanto o motor como o cognitivo (POLLITT e col.; 1986 e WALTER, 1993). A deficiência de ferro é, isoladamente, a carência nutricional mais comum no mundo (DeMAEYER, 1989, DALLMAN, 1989).

As estimativas publicadas no início da década de 90, situavam em pelo menos 1 bilhão, o número de pessoas portadoras de anemia ferropriva (UNITED NATIONS, 1992), sendo os grupos mais vulneráveis os lactentes, as crianças e as mulheres. A mais severa forma de deficiência desse mineral é a anemia e, embora a maior incidência seja encontrada em países em desenvolvimento, é comum nos países desenvolvidos (DeMAEYER, 1989).

No Brasil, os estudos de prevalência de anemia são dispersos e referem-se a grupos específicos da população. Em levantamento da literatura sobre esse assunto, observa-se que a grande maioria dos trabalhos foi conduzida na década de 80 e referem-se, especialmente, a grupos populacionais de crianças com menos de 6 anos de idade e gestantes (VANNUCHI, FREITAS \& SZARFARC, 1992).

Os resultados desses estudos apontam para a presença relevante da anemia nos segmentos populacionais considerados. Outros levantamentos apontam também o grupo de adolescentes como vulnerável à deficiência de ferro (DeMAEYER, 1985). Os escassos trabalhos dirigidos aos escolares também os incluem como importante grupo a ser considerado na questão de implantação de medidas preventivas. 
Em diagnóstico de anemia e desnutrição, feito em amostra representativa de escolares, ingressantes na $1^{\text {a }}$ série do $1^{\circ}$ grau da rede pública de um município, situado na Região Metropolitana da Grande São Paulo, em 1991, encontrou-se prevalência de 50\% de anemia (STEFANINI e col., 1995). Este resultado aponta provável tendência de aumento de casos no grupo de escolares quando comparado com estudo realizado em 1978, também com crianças da $1^{\circ}$ série do primeiro grau, em vinte escolas do município de São Paulo, que encontrou 20\% de anêmicos (NUSSENSWEIG, e col., 1982).

A anemia nutricional, como a desnutrição, também é determinada pelo consumo inadequado de alimentos, quer pela quantidade, quer pela dificuldade de consumo de alimentos fontes de ferro e/ou baixa biodisponibilidade desse nutriente ingerido (LAYRISSE e col., 1968). Há necessidade de, através da alimentação, além de suprir ferro nutricional em quantidade suficiente, assegurar que uma proporção adequada desse mineral seja absorvida.

A absorção de ferro pelo organismo depende, não só das reservas corporais, mas também, da forma e quantidade do mineral dos alimentos e da combinação dos mesmos em cada refeição. A quantidade de ferro absorvida deve ser equivalente à quantidade perdida que, em um indivíduo adulto normal, é cerca de $1 \mathrm{mg} /$ dia. Em situações de deficiência, o organismo absorve quantidades maiores desse nutriente que chegam até $4 \mathrm{mg} /$ por dia (MASSEY, 1992).

As quantidades recomendadas de consumo são influenciadas por dois fatores: os requerimentos individuais e a biodisponibilidade do ferro consumido (HALLBERG, 1981, INACG, 1984). Além destes, deve ser considerado o teor da vitamina C, como promotora da absorção de ferro, aspecto que tem sido frequentemente descrito na literatura (HALLBERG \& ROSSANDER, 1982; STECKEL e col., 1983). A vitamina C pode 
transformar em torno de $75 \%$ a $98 \%$ do ferro trivalente para sua forma divalente, mais solúvel e bem absorvida, dependendo do veículo; o ferro contido em pães, carnes e especialmente na gema do ovo, é menos susceptível à redução iônica que o contido nas frutas e vegetais (MARTÍNEZ-TORRES \& LAYRISSE, 1972).

De uma forma concisa, a anemia e a desnutrição têm como determinante direto a alimentação. Deve ser enfatizado que esse determinante direto ocorre como conseqüência das situações sociais, econômicas e biológicas que, quando adversas, levam a uma precariedade da qualidade de vida e de saúde da população. Embora a baixa renda desempenhe um papel importante na determinação da anemia ferropriva, sendo forte condicionante do consumo alimentar insuficiente, outros fatores devem ser considerados. Ressalta-se o acesso precário e a qualidade dos serviços de saúde, educação e saneamento, nem sempre satisfatórios. A escassez e a má distribuição desses serviços determinam práticas alimentares inadequadas e infestações parasitárias freqüentes, além de doenças infecciosas de repetição. Esses fatores, por sua vez, estão invariavelmente associados ao baixo poder aquisitivo.

O conhecimento das causas que determinam a ocorrência da desnutrição energético-proteica e da anemia ferropriva, bem como, a significativa prevalência dessas morbidades e suas implicações sinérgicas no estado de saúde da população, exigem definição de uma política abrangente que possibilite seu controle e prevenção.

Os estudos de prevalência dessas deficiências apontam como um dos grupos mais atingidos o de crianças menores de 5 anos, obviamente, pelo período de intenso crescimento nessa fase de vida e portanto de necessidade de maior quantidade relativa de nutrientes. Como já foi referido, entretanto, a presença dessas carências no grupo de escolares não é, absolutamente, desprezivel merecendo atenção do poder público. 
É evidente que a prevenção das carências nutricionais deve ser considerada desde o período gestacional e durante os primeiros cinco anos de vida quando o rítmo de crescimento é intensificado. Entretanto, a dificuldade de alcançar crianças da faixa de idade entre 1 a 6 anos, por não haver número de creches suficientes ou outros espaços institucionais para atendimento desse grupo, torna-o mais vulnerável às mesmas. Somente após os seis anos de idade as crianças vão para a escola, já então, com um quadro de carência estabelecido e havendo necessidade de intervenção para revertê-lo e não torná-lo mais severo (SZARFARC; STEFANINI \& LERNER, 1995).

O problema alimentar e suas conseqüências biológicas, necessariamente deve ser contemplado com políticas e programas de nutrição e alimentação, com os objetivos complementares de garantir o consumo adequado de alimentos e o aproveitamento biológico de nutrientes, em condições satisfatórias, para toda a população.

Sob uma óptica abrangente, assume-se a idéia de que os objetivos e estratégias de alimentação e nutrição devem fazer parte dos objetivos e estratégias das políticas nacionais de desenvolvimento econômico e social. Esta conduta não exclui a aplicação de medidas setoriais intervencionistas como as que se inserem na área de saúde ou de educação (BATISTA FILHO \& BARBOSA, 1985). Como medida intervencionista surgem os programas de suplementação alimentar.

$\mathrm{Na}$ história dos programas de suplementação alimentar no Brasil, desde sua origem, a merenda escolar esteve presente. As primeiras iniciativas datam da década de 30, quando alguns dos estados e municípios mais ricos, diante da escolarização obrigatória, passaram a responsabilizar-se, de forma crescente, pelo fornecimento da merenda em suas redes de ensino. No entanto, somente nos anos 50, criou-se o Programa Nacional de Alimentação Escolar. 
Dessa época até hoje, o Programa de Merenda Escolar manteve o objetivo de contribuir para melhorar as condições nutricionais e de saúde dos escolares, ao fornecer alimentação suplementar. A Merenda Escolar visa fornecer à criança algo mais do que ela recebe em casa. Na definição da sua composição nutritiva estabelece-se que deverá fornecer de $15 \%$ a $30 \%$ das quantidades diárias recomendadas de calorias e nutrientes $\left(\mathrm{FAE}^{\bullet}, 1996\right)$.

O Programa Nacional de Alimentação Escolar - PNAE•• destaca-se em dimensão, tempo de existência, manutenção, cobertura e período de permanência dentre os programas de suplementação alimentar, ainda que não esteja dirigido ao grupo de maior vulnerabilidade biológica. Considera-se, contudo, que a alimentação nas primeiras séries escolares, é um foco privilegiado de atuação: a logística da distribuição dos alimentos em quase a totalidade das escolas oficiais e filantrópicas do país, características ímpares do PNAE, permitia em 1990, atender a mais de 3000 municípios brasileiros e 20 milhões de escolares (PELIANO, 1992).

Em função desse meio fantástico que permite atuar no campo de política pública em nutrição, impõe-se a necessidade de aproveitá-lo de forma que contribua efetivamente na melhoria das condições de saúde e nutrição dessa população. A merenda escolar deve ser um meio eficaz para fornecer além da energia, os micronutrientes que dificilmente são oferecidos na alimentação diária em quantidades suficientes para atender as necessidades dos escolares, como mostram estudos de consumo.

Este estudo, ao reconstituir a trajetória do Programa de Merenda Escolar, como uma política pública aplicada no decorrer de quase cinqüenta anos, pretende verificar a sua contribuição no atendimento das necessidades nutricionais dos escolares. Tendo como

- FAE - Fundação de Assistência ao Estudante

- PNAE - Programa Nacional de Alimentação Escolar 
modelo o problema de carência de ferro e a necessidade de intervenção para o seu controle, pretende verificar a viabilidade de utilizar esse programa já estabelecido, para diminuir a prevalência de carências nutricionais específicas entre os seus usuários. 
2

$\checkmark$

\section{OBJETIVOS}


1) Reconstituir a evolução histórica do Programa de Merenda Escolar no Brasil e de suas metas em relação ao atendimento das necessidades nutricionais do escolar.

2) Avaliar a capacidade potencial da merenda no atendimento de necessidades nutricionais específicas de escolares. 


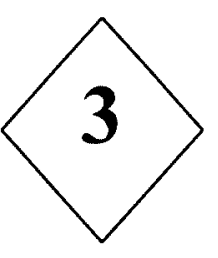

METODOLOGIA 
Para atender aos objetivos propostos, o estudo dividiu-se em três partes:

3.1 Pesquisa documental para se reconstituir a trajetória do Programa de Merenda Escolar, quando se procurou identificar fatos e argumentos que nortearam a sua existência nas diferentes correntes conceituais da saúde e nutrição. Utilizou-se:

A) fontes primárias - leis, decretos, portarias, relatórios institucionais e outros documentos que disciplinaram a ação do governo.

B) fontes secundárias: livros, teses, artigos científicos, relatórios de pesquisa e outros documentos que analisaram a intervenção governamental no setor.

Foram analisados nessas fontes, os objetivos do Programa de Merenda Escolar no decorrer de sua história, as formas de operacionalização, cobertura populacional e composição alimentar e nutricional dos cardápios.

3.2 Estudo da composição da merenda escolar.

Tendo como referência as informações constantes nos documentos pesquisados na $1^{\text {a }}$ parte do estudo, que reconstituiu a história do Programa de Merenda Escolar, aprofundou-se a análise da composição dos cardápios oferecidos na merenda escolar, quanto ao atendimento das necessidades nutricionais específicas, em diferentes momentos da história do programa.

\subsection{Estudo de caso}

Para avaliar a capacidade potencial da merenda no atendimento de necessidades nutricionais especificas, tomou-se como modelo a anemia ferropriva, uma vez que a 
mesma tem sido apontada como problema de saúde pública cada vez mais presente. Foi realizado um estudo de prevalência de anemia, em escolares do município de Santos, Estado de São Paulo. Foi verificada a composição da merenda escolar fornecida por esse município selecionado para o estudo da prevalência da deficiência de ferro. Analisou-se os cardápios oferecidos nas escolas durante um mês, segundo a frequência e composição de alimentos, no fornecimento de nutrientes essenciais, com a finalidade de propor modelo de intervenção.

\subsubsection{Caracterização do município}

A escolha do município de Santos para o estudo de prevalência de anemia não foi feita ao acaso. Santos apresentava alguns indicadores sociais que a colocavam numa situação vantajosa em relação a outros municípios do Estado de São Paulo.

Conforme os dados do IBGE, Censo 91, essa cidade tinha uma taxa de alfabetização de $94,6 \%$, apresentava índices de saneamento superiores à média das cidades brasileiras; a rede de água atendia $98 \%$ dos domicílios e a de esgotos $92,5 \%$. A renda média dos chefes de família alcançava 7,0 salários mínimos em 91 , próximo a do município de São Paulo. Houve investimentos importantes da administração municipal na área de saúde, saneamento e educação, ao longo dos seis últimos anos. A maior atenção dirigida às gestantes e aos recém-nascidos reverteu a curva de mortalidade infantil. A mortalidade infantil havia decrescido de 33,89 mortes por mil nascidos vivos em 1990, para 25,67 mortes por mil nascidos vivos em 1993. A estrutura populacional de Santos diferia da maioria dos municípios de São Paulo, uma vez que apresentava taxa geométrica de crescimento anual (TGCA) decrescente (2,66 em 1970, 1,89 em 1980 e 0,26 em 1991). A cobertura do grupo populacional de 7 a 14 anos 
matriculado no $1^{\circ}$ grau era praticamente total. As taxas de evasão das escolas de $1^{\circ}$ grau, em Santos foram em 1994, de 11,6\% das escolas estaduais, 2,2\% das escolas municipais e $0,15 \%$ das escolas particulares. (FERREIRA, e col., 1994).

Assim, encontrar, neste estudo, prevalência importante de anemia ferropriva em escolares desse Município com indicadores sociais relativamente favoráveis, indica que a preocupação com a qualidade da alimentação desse grupo populacional é relevante.

Outra razão que motivou a realização do estudo de caso em Santos, foi a existência de um Projeto de Lei, em tramitação, sobre a obrigatoriedade do enriquecimento dos alimentos destinados ao programa de merenda escolar, com ferro. Preocupados com o mérito desse projeto, as autoridades responsáveis pelo setor da saúde solicitaram um diagnóstico da situação de anemia em escolares.

O município de Santos, no litoral do Estado de São Paulo, abrange uma área de 39,40 km da ilha de São Vicente e uma extensão continental onze vezes maior. Na porção insular vive $99 \%$ da população de 438.468 habitantes, segundo o IBGE, 1996, sendo que sua ocupação urbana intensa e verticalizada se reflete numa densidade populacional de 10.548,27 habitantes por $\mathrm{Km}^{2}$ (CAMPOS \& HENRIQUES, 1997).

\subsubsection{População de estudo}

A população de estudo foi constituída por escolares matriculados nas 27 escolas municipais, situadas na porção insular da cidade de Santos, no ano de 1996, distribuídas por quatro zonas geográficas. Em função do objetivo de um diagnóstico que aponte a tendência da anemia ferropriva, decidiu-se amostrar a população constituída por escolares matriculados nas $1^{\text {as }}, 5^{\text {as }}$ e $8^{\text {as }}$ séries. Além do estudo nessas 
três séries apontarem uma tendência, elas concentram idades importantes do ponto de vista de vulnerabilidade à presença de anemia: a $1^{\text {a }}$ série, constituída de crianças de 7 a 8 anos de idade, marca o início da vida escolar e retrata a atenção recebida no período de vida anterior; a $5^{\text {a }}$ série constituida de crianças predominantemente de 11 e 12 anos de idade, marca o periodo inicial da adolescência e a $8^{\mathrm{a}}$ série é composta de adolescentes de 14 a 16 anos. A Tabela 1, descreve essa população, e o mapa que a acompanha (Figura 1) mostra a distribuição geográfica das escolas no município.

Tabela 1 - Número de classes e alunos matriculados na $1^{\mathrm{a}}, 5^{\mathrm{a}}$ e $8^{\mathrm{a}}$ séries do $1^{\mathrm{o}}$ grau nas escolas públicas, período diurno, distribuídos por escola e região de localização do Município de Santos/SP, 1996.

\begin{tabular}{|c|c|c|c|c|c|c|c|}
\hline \multirow{2}{*}{$\begin{array}{l}\text { NOME DA ESCOLA } \\
\text { (EMPG) } \\
\end{array}$} & \multirow{2}{*}{$\begin{array}{c}\text { REGIAO } \\
\text { GEOGRÄFICA DAS } \\
\text { ESCOLAS }\end{array}$} & \multicolumn{2}{|c|}{ I"SERIE } & \multicolumn{2}{|c|}{ 5" SERIE } & \multicolumn{2}{|c|}{$8^{4}$ SERIE } \\
\hline & & CLASSE & ALUNOS & CLASSE & ALUNOS & CLASSE & ALUNOS \\
\hline Pedro II & ORLA (I) & 3 & 109 & 4 & 107 & 3 & 111 \\
\hline Maria Luiza Alonso & 02 & 4 & 137 & - & - & - & - \\
\hline Lourdes Ortiz & 03 & 3 & 87 & 6 & 185 & 5 & 181 \\
\hline Auxiliadora da Instrução & 04 & 5 & 174 & - & - & - & - \\
\hline Cidade de Santos & 05 & 4 & 138 & 4 & 173 & 5 & 185 \\
\hline Embaré & 06 & 3 & 92 & 4 & 123 & 1 & 37 \\
\hline Dino Bueno & 07 & 4 & 131 & - & - & - & - \\
\hline Edméia Ladevig & 08 & 4 & 131 & 6 & 175 & 2 & 78 \\
\hline Ruy Ribeiro Couto & 09 & 3 & 124 & - & - & - & - \\
\hline Barão do Rio Branco & 10 & 5 & 178 & - & - & - & - \\
\hline Olavo Bilac & 11 & 4 & 144 & - & - & - & - \\
\hline Ayrton Senna & 12 & - & - & 4 & 152 & 5 & 187 \\
\hline Vila Belmiro & 13 & - & - & 8 & 245 & - & - \\
\hline & CENTRO (II) & & & & & & \\
\hline Gota de Leite & 14 & 1 & 36 & 2 & 75 & 1 & 33 \\
\hline Docas de Santos & 15 & 5 & 175 & - & - & - & - \\
\hline 28 de Fevereiro & 16 & 5 & 178 & - & - & - & - \\
\hline Avelino de Paz Vieira & 17 & 6 & 211 & 6 & 201 & 2 & 75 \\
\hline Martins Fontes & 18 & 2 & 73 & 3 & 119 & 1 & 48 \\
\hline Mário de Andrade Alcântara & 19 & 4 & 114 & 5 & 163 & 2 & 66 \\
\hline & NOROESTE (III) & & & & & & \\
\hline Fernando Costa & 20 & 6 & 213 & - & - & - & - \\
\hline Padre Leonardo Nunes & 21 & 3 & 116 & 6 & 199 & 3 & 91 \\
\hline Benevenuto & 22 & 3 & 120 & - & - & - & - \\
\hline Pedro Crescenti & 23 & 8 & 295 & - & - & - & - \\
\hline Paulo Figueira Jr & 24 & 4 & 147 & - & - & - & - \\
\hline José Carlos Azevedo & 25 & 1 & 70 & 1 & 44 & 1 & 20 \\
\hline José da Costa Sobrinho & 26 & 2 & 61 & 1 & 31 & 1 & 19 \\
\hline & MORROS (IV) & & & & & & \\
\hline José Genésio & 27 & 3 & 107 & 2 & 73 & - & - \\
\hline TOTAL & & 95 & 3361 & 62 & 2065 & 32 & 1131 \\
\hline
\end{tabular}

Fonte: Secretaria Municipal de Educação, Santos, SP 
Figura 1 - Distribuição geográfica, por bairro, das escolas municipais de primeiro grau, ano de 1996, Municipio de Santos, São Paulo*

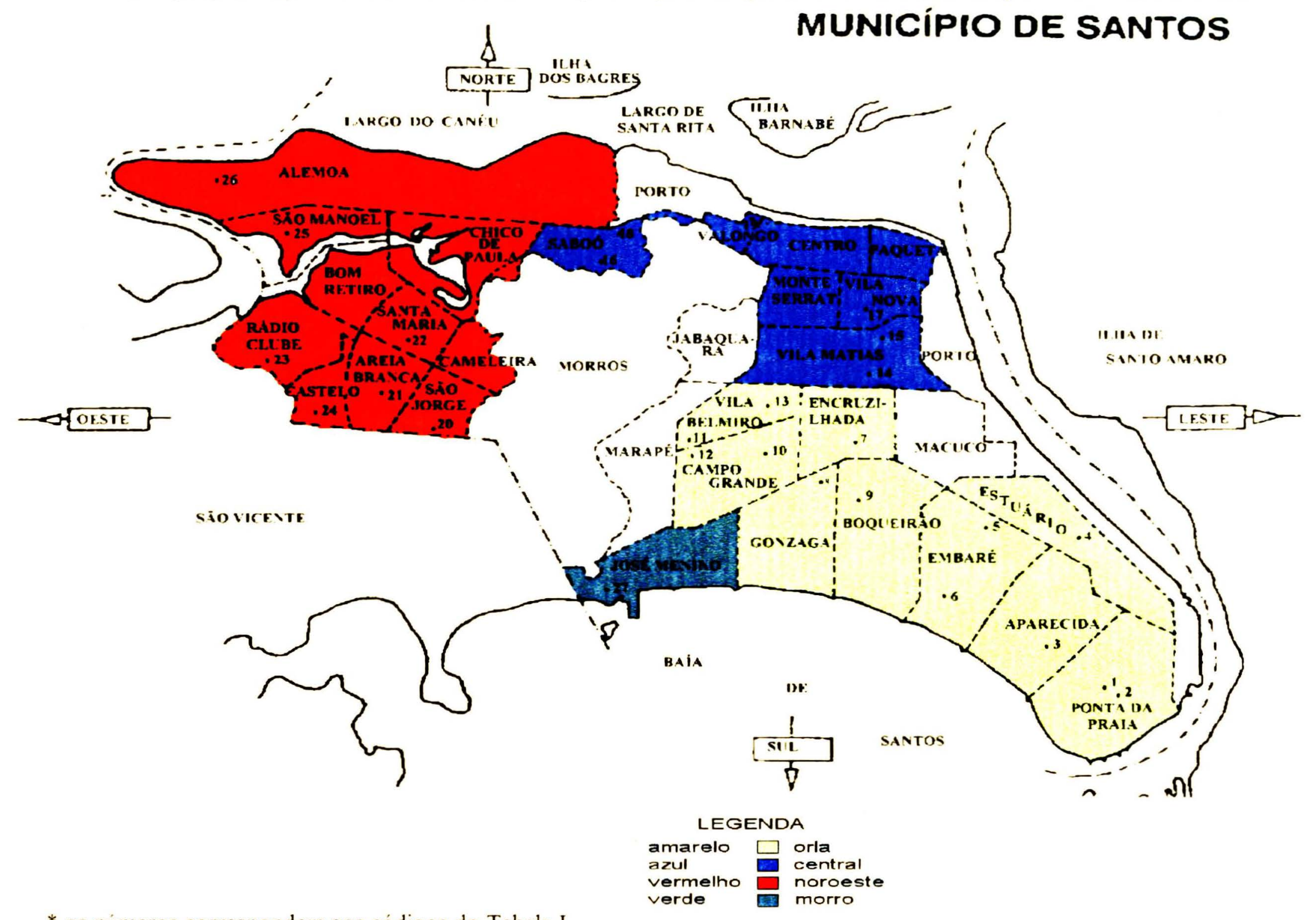

* os números correspondem aos códigos do Tabela I 
Observa-se na tabela acima a queda expressiva do número de classes e de escolares da $1^{\text {a }}$ série para a $5^{\mathrm{a}}$ e da $5^{\mathrm{a}}$ para a $8^{\mathrm{a}}$ série, demonstrando um afunilamento da participação na formação educacional: eram, no primeiro momento, 95 classes de $1^{\text {as }}$ séries, passando para 62 classes de $5^{\text {as }}$ séries e finalmente 32 de $8^{\text {as }}$ séries, sendo a média de alunos por classe mantida em torno de 35 para as três séries. Dados oficiais da Secretaria Estadual da Educação de São Paulo registram que o Município de Santos, no ano de 1996, apresentou taxa média de evasão de $8,91 \%$ na $1^{\mathrm{a}}$ série, $10,54 \%$ na $5^{\mathrm{a}}$ e $7,94 \%$ na $8^{\mathrm{a}}$ série. Entretanto há grande variação dessas taxas entre as escolas.

\subsubsection{Amostragem}

Foi estabelecido um plano de seleção, com dupla estratificação: a distribuição das escolas por regiões geográficas, tentando estabelecer um possível controle sobre as variáveis sócio-econômicas e a distribuição dos alunos por séries escolares, tentando um possível controle sobre a variável idade, já que a série escolar pode ser tomada, aproximadamente, como um indicador associado à mesma. À falta de uma investigação piloto no município em questão, assim como, dados na literatura, foi assumida a prevalência de $50 \%$ para a qual corresponde a maior variância. Este valor está próximo daquele encontrado para escolares ingressantes na $1^{\text {a }}$ série das escolas públicas do município de Osasco, SP (STEFANINI e col., 1995). Utilizou-se a teoria de amostragem estratificada em dois estágios: no primeiro, selecionou-se escolas dentro dos estratos geográficos e no segundo, selecionou classes, respeitando-se a estratificação por séries. A amostragem foi feita para três regiões geográficas, Orla, Central e Noroeste. A região "Morro" não foi incluída no plano amostral por contar com apenas uma escola, e por haver 
interesse em incluí-la no estudo. A alocação proporcional das escolas e das classes na amostra, por série escolar e por região geográfica está disposta na Tabela 2:

Tabela 2 - Números de escolas e de classes pertencentes à amostra para estimação da anemia ferropriva, segundo região geográfica e séries escolares, Município de Santos/SP, 1996.

\begin{tabular}{|c|c|c|c|c|c|c|c|c|}
\hline \multirow{2}{*}{$\begin{array}{c}\text { REGIĀO } \\
\text { GEOGRÁFICA }\end{array}$} & \multicolumn{2}{|c|}{$1^{n}$ SERIE } & \multicolumn{2}{|c|}{$5^{\mathrm{a}}$ SERIE } & \multicolumn{2}{|c|}{$8^{n}$ SERIE } & \multicolumn{2}{|c|}{ TOTAL } \\
\hline & $\begin{array}{c}N^{\circ} \text { DE } \\
\text { ESCOLAS }\end{array}$ & $\begin{array}{c}\mathrm{N}^{\circ} \mathrm{DE} \\
\text { CLASSES }\end{array}$ & $\begin{array}{c}\mathrm{N}^{\circ} \mathrm{DE} \\
\text { ESCOLAS }\end{array}$ & $\begin{array}{c}\mathrm{N}^{\circ} \mathrm{DE} \\
\text { CLASSES }\end{array}$ & $\begin{array}{l}\mathrm{N}^{\circ} \mathrm{DE} \\
\text { ESCOLAS }\end{array}$ & $\begin{array}{c}\mathrm{N}^{\circ} \mathrm{DE} \\
\text { CLASSES }\end{array}$ & $\begin{array}{c}\mathrm{N}^{\circ} \mathrm{DE} \\
\text { ESCOLAS }\end{array}$ & $\begin{array}{c}\mathrm{N}^{\circ} \mathrm{DE} \\
\text { CLASSES }\end{array}$ \\
\hline ORLA & 4 & 7 & 2 & 5 & 1 & 2 & 7 & 14 \\
\hline CENTRAL & 1 & 2 & 1 & 2 & 1 & 1 & 3 & 5 \\
\hline NOROESTE & 2 & 4 & 1 & 1 & 1 & 1 & 4 & 6 \\
\hline MORRO & 1 & 1 & 1 & 1 & - & - & 2 & 2 \\
\hline TOTAL & 8 & 14 & 5 & 9 & 3 & 4 & 16 & 27 \\
\hline
\end{tabular}

\subsubsection{Variáveis estudadas}

a. Concentração de hemoglobina - O diagnóstico da anemia foi feito através da dosagem da concentração sanguínea de hemoglobina, utilizando fotômetro de alta precisão HemoCue. É um instrumento portátil que apresenta o resultado direto da concentração da hemoglobina sanguínea em menos de 45 segundos, sem a necessidade de cálculos. O sangue, colhido por punção digital com lanceta descartável, é introduzido no aparelho utilizando-se lâmina apropriada, também descartável e em poucos segundos, é efetuada a leitura; o valor da hemoglobina é apresentado digitalmente (USAID, 1996).

A colheita sanguínea foi feita por técnicos habilitados da Faculdade de Saúde Pública da USP. Os critérios da OMS* para diagnóstico de anemia (DeMAEYER, 1989), foram os utilizados neste estudo:

Idade (anos)

6 a 14 (ambos os sexos)

$\geq 15$ homens

$\geq 15$ mulheres limite inferior de hemoglobina $(\mathrm{g} / \mathrm{dl})$

12,0

13,0

12,0

\footnotetext{
* OMS -Organização Mundial de Saúde
} 
b. Peso e Altura - Para conhecer o estado nutricional foram utilizados os indicadores de peso e de altura para idade e sexo, que definem o perfil antropométrico e o estado nutricional da população; utilizou-se o "Z-SCORE” ( $n^{\circ}$ de desvios-padrão distante da mediana da população de referência em relação ao peso e a altura da criança) e a população de referência foi a do National Center for Health Statistics-NCHS (1977), conforme recomendação da OMS (WHO, 1986).

A medida do peso foi feita com balança eletrônica portátil, marca Soehnle, produzida na Alemanha, com capacidade para $150 \mathrm{Kg}$ e precisão de $100 \mathrm{~g}$.

A altura foi medida através do estadiômetro portátil, (trena fabricada pela Stanley Mabo, na França), graduado em décimos de centímetros. Foi utilizado um degrau de madeira para anular a diferença do rodapé, durante a tomada da medida.

Utilizou-se o pacote estatístico EPINFO versão 6.0 Dos para cálculos antropométricos e de idade e o programa SPSS* versão 6.0 Windows para os estatísticos.

c. Escolaridade do pai ou responsável - A escolaridade do pai ou responsável foi utilizada para definir o nível sócio-econômico da população dos escolares; conforme proposto por ZURAYK e col. (1987). Esses autores encontraram grande dependência entre a escolaridade e a classe social, havendo forte associação entre o nível de escolaridade e a renda. Além disso, há facilidade na obtenção dessa variável. Adotouse, neste estudo, as categorias: analfabeto - não estudou e não sabe ler/escrever; primário incompleto - estudou de 1 a 3 anos; primário completo - estudou de 4 a 7 anos; ginásio completo - estudou 8 anos e concluiu o primeio grau; acima de 8 anos, para $2^{\circ}$ grau incompleto, $2^{\circ}$ grau completo, superior incompleto e superior completo.

d. Região geográfica - A localização das escolas em regiões geográficas foi uma variável utilizada como um marcador sócio-econômico. O município de Santos é subdividido em quatro regiões geográficas, ocupadas desorganizadamente: orla, onde se concentra o maior número de escolas, serviços de saúde e a população de melhor nível sócio-econômico; central caracterizada pela presença crescente de habitações coletivas, os morros, ocupados sem a preocupação com saneamento e o perigo de

- SPSS - Statistical Package for the Social sciences 
desmoronamentos e a noroeste, área de mangues, margeadas por favelas sobre palafitas (CAMPOS \& HENRIQUES, 1997).

\subsection{Estratégia de campo}

a. Cada equipe de campo foi composta de quatro pessoas, sendo dois antropometristas e dois técnicos de coleta de sangue e leitura que foram devidamente treinados e supervisionados.

b. Os resultados dos exames foram encaminhados por escrito, para os diretores das escolas e nominalmente para cada criança, por classe e por escola acompanhados de recomendações.

c. Durante a fase de campo foi realizada entrevista com os responsáveis pelo Programa de Merenda Escolar do municipio.

d. Competiu à Escola:

- fornecer a listagem dos alunos das classes sorteadas contendo nomes dos alunos, sexo, data de nascimento, série e horários de aulas;

- encaminhar as cartas, fornecidas pelos pesquisadores (ANEXO I), aos responsáveis pelos alunos solicitando informações sobre medicamentos que estavam tomando, a escolaridade e ocupação dos pais e autorização para a coleta de sangue.

- preencher os questionários sobre a alimentação institucional: $\mathrm{n}^{\circ}$ de refeições, horários, composição dos cardápios. 
A apresentação dos resultados foi subdividida em dois componentes procurando atender aos objetivos propostos: o primeiro, referente à reconstituição da trajetória do Programa de Merenda Escolar, suas metas e atendimento das necessidades; o segundo, um estudo de caso para ilustrar a presença de problemas de carência nutricional com vistas a sugerir formas de prevenção, utilizando o Programa de Merenda Escolar.

A reconstrução da trajetória exigiu uma subdivisão em itens, de forma a facilitar a leitura e interpretação do conteúdo denso de informações.

O desenvolvimento dos itens: - 4.1.1 Introdução às políticas de alimentação e nutrição em nível internacional e 4.1.2 Politica de Alimentação e Nutrição no Brasil e Programa de Merenda Escolar - procurou seguir a ordem cronológica dos acontecimentos relacionados ao estado da arte nos campos da saúde e nutrição. 


\subsection{RECONSTITUIÇÃO DA TRAJETÓRIA DO PROGRAMA DE MERENDA ESCOLAR}

\subsubsection{Introdução às políticas de alimentação e nutrição em nível internacional}

A preocupação com o bem estar de mães e crianças não é recente. Foi registrada na Inglaterra, por volta de 1748 com o escrito "Um ensaio sobre a amamentação e o manejo de crianças" por Willian Cardogan, onde o autor defendeu o direito das crianças à vida e à liberdade e ditou algumas regras empíricas para amamentação e alimentação e outros cuidados. A decretação da Lei da Saúde Pública ("Public Health Act”), nos Estados Unidos, em 1848, marca o início da política de saúde decorrente da atuação da Associação pela Saúde das Cidades ("Health of Towns Association") fundada em 1844 e que representou a primeira tentativa de organização da comunidade em torno de problemas sociais e sanitários. Na França e na Alemanha também surgiram no século XVIII, ações direcionadas ao bem estar e à saúde de crianças e de mulheres grávidas; mas foi no final do séc. XIX e início do atual que a preocupação com todas as fases da vida infantil se mostrou uma característica eminente do movimento por melhorias sociais, nos Estados Unidos e Europa Ocidental. O enfoque residia na higiene geral para prevenção de doenças, no aperfeiçoamento da dieta e cuidados pré-natais (ROSEN 1994).

Ainda segundo ROSEN, as razões de preocupação com as crianças foram de ordem política, econômica e humanitária: o decréscimo no número de nascimentos após 1870, na Europa e Estados Unidos e a necessidade de homens jovens e saudáveis para servir às forças armadas. Essa preocupação, não por acaso, coincide com o reaparecimento de idéias e políticas mercantilistas, de empenho em conquistar colônias, garantir mercados e fontes de matérias primas. Os estudiosos sabiam que as causas da alta mortalidade das 
crianças eram a desnutrição, a ignorância dos pais, o alimento contaminado e outros fatores ligados à pobreza. O problema precisava ser atacado em frentes distintas: por meio de provisão de leite puro, instrução da mãe sobre alimentação e cuidados da criança, legislação do trabalho de gestantes, criação de creches e estímulo ao aleitamento materno (ROSEN, 1994).

Com relação à saúde da criança em idade escolar, também a partir do séc. XVIII notam-se alguns passos na direção do desenvolvimento de serviços de saúde. Na França, a convenção de 1793 aprovou o princípio das inspeções médicas nas escolas mas não se tomou nenhuma atitude nesse sentido, até o séc. XIX. Essa medida somente foi instalada em 1879.

A Alemanha foi o segundo país a desenvolver um sistema de supervisão de saúde de escolares. Os primeiros serviços médicos nas escolas da Europa foram instituidos em Bruxelas (1874), Suécia (1878) e Inglaterra, em 1907. Nos Estados Unidos a inspeção médica escolar começou por volta de 1870 , de forma esporádica e se estabeleceu somente em 1894 devido à epidemia de difteria (MARTINS, 1985).

O movimento pela merenda escolar se iniciou em Nova York, em 1908, como um esforço para suplementar a dieta de crianças subnutridas. Era oferecida uma merenda quente, ao meio dia, para as crianças pobres. Estudos realizados em 1917, estimaram que $21 \%$ das crianças das escolas da cidade de Nova York sofriam de subnutrição; em 1918 encontrou-se a prevalência de 15 a $25 \%$ nos escolares dos Estados Unidos. Somente na década de 30 a Merenda Escolar se instalou. Em 1935, a Corporação Federal das Mercadorias Excedentes, aproveita a existência do programa de merenda escolar para reduzir os excedentes agrícolas. Ao fim de 1938, quarenta e cinco estados americanos participavam do programa de distribuição de merenda escolar. Nesse programa enfatizava- 
se a educação em nutrição, um assunto introduzido no currículo da escola pública em 1918 e desde então, componente regular da educação elementar, primária e secundária. Esse processo foi formalizado em 1946 com o "Ato Nacional da Merenda Escolar" (National Lunch Act) que previa subsídios aos programas administrativos estaduais (EGAN, 1994).

O processo de atenção ao escolar dos Estados Unidos encontrava paralelo na.Grã Bretanha e Japão. Dava-se especial atenção ao estado nutricional dos escolares.

O Japão realizava, em 1889 , um programa alimentar para crianças pobres e mal nutridas que se manteve e expandiu a tal ponto que, atualmente, a distribuição de merenda atinge a maioria dos escolares desde os da pré-escola até os alunos dos níveis secundários (EGAN, 1994). Em 1904, a Grã Bretanha sancionou o Ato de Provisão das Refeições (Provision of Meals Act) que organizava o fornecimento de refeições para crianças da escola elementar. Em 1934 introduziu-se o leite nos planos escolares, subsidiado com fundos públicos. A Segunda Guerra Mundial expandiu esse esquema em 1944 com o "Ato da Educação”, e as Regulamentações da Provisão de Leite e Refeições (“Provision of Milk and Meals Regulation") que obrigavam as autoridades educacionais a fornecer merenda a todas as crianças que desejassem. Este foi um reflexo do "Relatório Beveridge", de 1942, intitulado Seguridade Social e Serviços Afins (Social Insurance and Allied Services) que considerava a necessidade de se cuidar da saúde de forma abrangente, como parte de uma política social nacional (ROSEN, 1994).

Ainda, segundo Rosen, na Inglaterra, em 1943, o governo anunciou a aprovação da política de um serviço nacional de saúde, lançado como uma grande experimentação, organizado por uma comunidade industrializada moderna, que se propôs a administrar os recursos de saúde existentes de maneira democrática, em benefício do povo: um marco na história da saủde comunitária. 
A atuação do governo inglês relativa à nutrição se firmou, estimulada pela crise econômica mundial, de 1929 a 1936, quando a desnutrição generalizada se seguiu ao desemprego em massa. Depois, foi intensificada pelas necessidades impostas pela Segunda Guerra Mundial, devido à escassez de alimentos, ao racionamento e à necessidade de proteger trabalhadores, mulheres e crianças.

Nos Estados Unidos, paralelamente ao programa da Corporação Federal de Artigos Excedentes para a merenda escolar e outros programas, inaugurou-se, em 1939, o Plano Selo-Alimento (Food-Stamp), subsidiado pelo Governo, para oferecer suplementação alimentar através de mercados locais à famílias de baixa renda (EGAN, 1994).

Na Grã Bretanha a manutenção do nível nutricional do povo e, em especial das mães e crianças, mereceram grande preocupação durante a guerra; a política geral era a de garantir a todas as pessoas todos os nutrientes essenciais nas quantidades necessárias para manter a saúde. Alguns alimentos como a margarina e a farinha foram fortificados pela adição de vitaminas $\mathrm{A}$ e $\mathrm{D}$, minerais e cálcio.

Os Estados Unidos passaram, devido à Guerra, em janeiro de 1943, a enriquecer alimentos: pão branco tinha que ser fortalecido com niacina, riboflavina, tiamina e ferro. Atualmente, 26 estados e os territórios do Havaí e Porto Rico, seguem essa legislação.

O conhecimento acadêmico-científico, na área de alimentação e nutrição intensifica-se no período de 1915 a 1935, quando foram criados, em vários países, centros e comissões de pesquisa ligados ao campo da alimentação e nutrição, direcionados a estudarem as necessidades nutricionais e alimentares do ser humano, e os recursos disponíveis para satisfazê-las. 
$\mathrm{Na}$ década de 30, a Liga das Nações reconhecia que a solução dos problemas existentes no campo alimentar e nutricional teria que passar pela resolução da questão social de pobreza onde estava a raiz das suas causas (COMITÊ MISTO FAO/OMS, 1976). Uma publicação da Repartição Internacional do Trabalho intitulada "Inquéritos sobre a alimentação nos países americanos", registra a preocupação da XI Conferência Sanitária Panamericana e da Organização Internacional do Trabalho com os métodos e os resultados dos inquéritos sobre alimentação que contribuiram para a elaboração de uma política alimentar comum. É um marco na história do encontro de vários países para discutirem a questão alimentar e nutricional (REPARTIÇÃO INTERNACIONAL DO TRABALHO, 1943).

No final da década de 40 e princípio dos anos 50, era enfatizado o conhecimento que a subnutrição na infância era um problema grave de saúde pública na maioria dos países da América Latina. Considerava-se que as altas taxas de mortalidade e morbidade, prevalentes em crianças, eram consequentes aos processos infecciosos e parasitários. Federico Gomez e col., (GOMEZ e col., 1956) no México e Julio Meneghello, no Chile, foram os pioneiros a assinalar o problema e a magnitude da desnutrição como fator agravante dessa situação. Estudos epidemiológicos do Instituto de Nutrição do Centro América e Panamá (INCAP*), localizado na Guatemala, ampliaram o entendimento da gravidade do problema em nível social (BEHAR, 1976).

Desde então, grande variedade de programas têm sido colocados em prática com a intenção de combater a desnutrição. Inicialmente, no começo da década de 50, a maioria dos países da América Latina faziam a distribuição gratuita do leite devido à excedentes desse alimento em países produtores. O programa foi suspenso quando diminuiu a

\footnotetext{
INCAP - Instituto de Nutricion de Centro América y Panama
} 
produção. Como experiências importantes desse programa distributivo que durou muitos anos, podem ser atribuídos: o melhor conhecimento da contaminação do leite a maior ocorrência da diarréia como conseqüência; a existência da diluição intrafamiliar ou venda do produto doado; o não acesso ao programa, das crianças mais carentes, o desmame precoce, e também, e principalmente, a não resolução do problema da subnutrição (BEHAR, 1991; STEFANINI e col., 1994).

Nesse período dos anos 50, a corrente de pensamento ditada pelos órgãos internacionais, Organização Panamericana de Saúde-OPS* , Organização das Nações Unidas para Agricultura e Alimentação-FAO"* e Fundo Internacional de Socorro à Infância das Nações Unidas-UNICEF”** , conduziu a implementação de programas e projetos de nutrição e introduziu, na maioria dos países da América Latina, os programas de distribuição gratuita de alimentos.

A condução dessa corrente de pensamento foi marcada com a realização de três conferências sobre os problemas de nutrição nas Américas, promovidas por esses órgãos internacionais. A primeira realizada em Montevidéo, em 1948, e a segunda no Rio de Janeiro em 1950, recomendaram estudos sobre metodologias e práticas alimentares, composição de alimentos e programas de alimentação escolar, além do enfoque em educação alimentar. A $2^{\mathrm{a}}$ Conferência recomendou também, que se estimulasse, com prêmios e bolsas, os especialistas e institutos de nutrição que treinassem recursos humanos para inquéritos alimentares. Consideravam a subnutrição resultante da ignorância e enfocavam a necessidade de programas educativos.

\footnotetext{
* OPS - Organização Panamericana de Saúde

** FAO - Organização das Naç̃̃es Unidas para Agricultura e Alimentação

*** UNICEF - Fundo Internacional de Socorro à Infância das Nações Unidas - (United Nations International Children Emergency Fund United)
} 
A terceira Conferência, realizada em Caracas, em 1953, descreveu o estado de deficiência proteica, comum a vários países, conhecida como síndrome pluricarencial infantil ou "Kwashiorkor", presente na América Latina, apresentado principalmente por crianças após o desmame e em pré-escolares, decorrente do consumo insuficiente de alimentos ricos em proteínas de alto valor biológico, leite, carnes e ovos, devido à baixa produção e preços altos. Recomendou tratamento e insistiu na prevenção por meio de alimentação complementar para melhorar a nutrição da mãe e da criança; recomendou também, a adoção de uma política nacional de alimentação e nutrição (CASTRO BARBOSA \& SANTOS, 1954).

Nos capítulos "nutrição em programas de saúde pública", "enriquecimento de alimentos" e "desnutrição proteica" do documento final dessa Conferência, destacam-se as recomendações: que os centros de saúde considerassem os programas de nutrição como uma de suas rotinas; que se utilizassem misturas de alimentos naturais, antes de recorrer ao enriquecimento com produtos químicos; que as medidas de saúde pública, para prevenção da desnutrição, privilegiassem a orientação das mães gestantes, que eram ignorantes e possuiam hábitos alimentares e tabus que restringiam o consumo; que era necessário investigar alimentos pouco conhecidos; que a distribuição de leite integral ou desnatado fosse efetuada nas unidades de saúde; que o aleitamento prolongado fosse incentivado só para os locais onde não se dispunha de leite ou outros alimentos para os lactentes; que houvesse complementação após os seis meses de vida e, finalmente, recomendou a investigação de preparação de fórmulas apropriadas para completar a dieta de lactentes e crianças usando trigo, soja, milho e leite em pó (OFICINA SANITÁRIA PANAMERICANA, 1954). 
Essas três Conferências conduziram a introdução dos programas de suplementação e complementação alimentar nos países latino-americanos, com destaque especial para a alimentação de crianças escolares.

Os anos 50 foram marcados pela divisão cada vez mais polarizada entre os países capitalistas e socialistas que caracterizou o período pós Segunda Guerra. As grandes potências capitalistas, lideradas pelos Estados Unidos, preocupadas com a propaganda do socialismo, procuraram, através de organismos internacionais, como por exemplo, a Organização das Nações Unidas-ONU* , estabelecer programas de assistência técnica à agricultura, de desenvolvimento de comunidade e de ajuda alimentar.

Os programas de ajuda alimentar estabelecidos através da ONU , FAO e UNICEF, que se expandiram especialmente nessa década, serviram também para o escoamento dos excedentes de produção do Canadá e dos Estados Unidos, que haviam alcançado grande desenvolvimento agrícola a partir da chamada "Revolução Verde" (GOLDENBERG, 1989). Em 1954, através da "Lei dos Alimentos para a Paz", os Estados Unidos passaram a regulamentar essas “doações”.

Cabe aqui um parênteses para relatar um fato, no mínimo, curioso. Em 1954, no programa de ajuda alimentar "Food for Peace" foi incluído o tabaco para ser distribuído aos países em vias de desenvolvimento. O Ministério de Agricultura dos Estados Unidos expedia, anualmente, dez milhões de dólares de tabaco com a quota destinada aos países que sofriam de fome. Essa prática foi abandonada somente nos anos 80. Hoje os Estados Unidos são os maiores exportadores de tabaco: $31 \%$ de sua produção total é exportada. Enquanto o consumo de cigarros nas décadas de 70 a 80, declinou nos Estados Unidos, aumentou $33 \%$ na África e $24 \%$ na América Latina. Depois de 1964 , com a campanha do

• ONU - Organização das Naç̃es Unidas 
Ministério de Saúde, nos Estados Unidos, 38 milhões de adultos cessaram de fumar, enquanto no mesmo período (1960 a 1980) o consumo de cigarros aumentou $400 \%$ na Índia e 300\% na Nova Guiné. Em 1990 o tabaco era o produto agrícola não alimentar mais cultivado em 120 países e, nos países em desenvolvimento, $72 \%$ da superfície agrária total eram destinadas a sua cultura. Estima-se que o tabaco ocupava o espaço de culturas alimentares que poderiam nutrir de 10 a 20 milhões de pessoas (BARRY, 1991).

Nessa mesma linha de doações, os organismos internacionais instituíram a suplementação alimentar voltada ao grupo materno-infantil e escolar nos países em desenvolvimento.

Vale a pena enfatizar que por ocasião da $1^{\text {a }}$ Conferência, em 1948, foi proposto programa de alimentação complementar para os escolares e na $3^{a}$ Conferência, seis anos depois, foram constatados progressos consideráveis: se conhecia a expansão do programa dirigido à maioria dos escolares de zonas urbanas e rurais de Porto Rico, que recebiam leite desnatado e margarina enriquecida com vitamina A. Na Venezuela, em 1952, eram fornecidos 10,32 milhões de almoços escolares. No Brasil, quatorze, dos vinte e cinco estados na época, tinham programas de almoço subvencionados pelos governos locais.

No final da década de 50 e início dos anos 60, o Fundo Internacional de Socorro à Infância - UNICEF, a FAO - Organização das Nacões Unidas para Agricultura e Alimentação e a OMS implantaram o Programa Integrado de Nutrição Aplicada (PINA) em alguns países da América Latina. O enfoque principal era educativo. Era um programa que buscava integrar setores por meio de ações nas escolas, centros de saúde e na agricultura. As escolas, com a assessoria dos órgãos da agricultura, passaram a formar as hortas escolares, envolvendo as crianças num processo educativo de produção e consumo dos alimentos. Nos centros de saúde, as mães recebiam educação alimentar. Foi um 
programa vertical que exigia muito esforço e tempo, com integração dos professores já sobrecarregados. O mesmo ocorria com a equipe de saúde e de agricultura. Mesmo assim os PINAs funcionaram por vários anos e foram suspensos quando terminou a ajuda externa (BEHAR, 1991).

Durante a década de 60 , quando a prevalência alta da desnutrição era creditada a escassez de recursos para a compra de alimentos proteicos, surgem as misturas de vegetais para substituí-los, com destaque para o leite, alimento de custo muito elevado.

A ajuda internacional se volta para o estímulo do desenvolvimento de produtos e aparecem as misturas, utilizando excedentes de cereais e soja. Surge a Incaparina na Guatemala e outras misturas semelhantes em vários países da América Latina (Colombina, Peruvita, etc). Voltam os grandes programas de distribuição de alimentos com a ajuda externa - misturas vegetais. Os critérios não se baseavam em risco nutricional. Desconsidera-se adequação cultural ou aceitabilidade. A avaliação se limitava a medir as quantidades de alimentos distribuídos.

\subsubsection{Política de Alimentação e Nutrição no Brasil e o Programa de Merenda Escolar}

A prática de saúde pública no Brasil, iniciada na década de 1920, com a formação de uma sociedade urbano-industrial, recebeu grande impulso após a revolução de 1930, com o fortalecimento do Estado. Inaugurou-se a política nacional de saúde, criou-se o Ministério da Educação e Saúde; em 1934 surgiu o Departamento Nacional de Assistência Médico-Social, cujo enfoque se dirigiu aos grupos ligados à produção e ao binômio materno-infantil.

No começo da década de 30 , foram iniciados os inquéritos nutricionais, que ampliaram a consciência sobre os fatores que envolvem o problema da fome e da 
subnutrição, por meio do avanço na cientificidade das pesquisas. O primeiro exemplo de metodologia de inquérito no Brasil data de 1932 e foi conduzido por Josué de Castro, em Recife, voltado para as condições alimentares da classe operária, abrangendo 500 famílias num total de 2.585 pessoas (CASTRO, 1939). Seus resultados revelaram um regime alimentar insuficiente e carenciado, caracterizado por terrível monotonia (falta de variedade de substâncias que entram no cardápio), rico em carbohidratos e de baixo valor calórico. Composto quase que exclusivamente de farinha com feijão, charque, café e açúcar (CASTRO, 1957).

A esse, seguiram-se outros também dirigidos por Josué de Castro e em 1943, o Departamento Nacional de Saúde promoveu uma série de inquéritos nas capitais brasileiras, com enfoque na cobertura de população como um todo, avaliando-se o estado nutricional através da comparação da ingestão de alimentos com necessidades padronizadas, pretendendo investigar a dimensão quantitativa e não qualitativa. Retrataram uma situação alimentar precária e, embora evidenciassem o caráter social da má alimentação, não o expuseram em toda sua dimensão (CASTRO, 1965; COIMBRA e col., 1982).

As pesquisas mais importantes feitas com escolares foram de autoria de Dante Costa, em 1942 e 1948, em escolas públicas primárias do Rio de Janeiro, denunciando prevalência de deficiências de tiamina, vitamina A e proteínas (COSTA, 1960 apud. COIMBRA e col., 1982).

O Brasil, segundo Batista Filho, tem sido um dos países em que se testemunha, há muito tempo, um interesse explícito pela área de alimentação e nutrição. Menciona, como exemplos, as medidas dos governos coloniais, que tornaram obrigatório o plantio de mandioca nas áreas cultivadas com cana no Nordeste, como forma de melhorar a 
alimentação das populações empregadas na exploração da monocultura do açúcar e a criação do Comissariado de Alimentação Pública, em 1918, para atender a “crise de carestia" agravada pela primeira guerra mundial, fato que assinala tomada da posição do poder governamental. A partir de 1930, o governo brasileiro define maior interesse pelos problemas alimentares. Em 1937 criou a Comissão Reguladora de Tabelamento e, no ano seguinte, oficializou a importante medida da decretação da Lei do Salário Mínimo. De acordo com essa Lei, o salário deve ser estabelecido segundo uma estimativa que assegure $50 \%$ do seu valor para a compra de alimentação essencial mínima, capaz de atender a cobertura das recomendações de energia e nutrientes (BATISTA FILHO \& BARBOSA, 1985).

Pelos "Arquivos Brasileiros de Nutrição", publicação que marcou presença no Brasil num considerável período de vinte quatro anos, de 1944 a 1968, encontram-se registrados órgãos e comissões governamentais, criados durante esse longo tempo, que imprimiram as diretrizes das políticas de nutrição no País, e que caracterizaram as formas iniciais dos programas posteriores.

Pode-se mesmo considerar que um marco na política nacional de nutrição aconteceu em 1940, ano em que se criou o Serviço de Alimentação da Previdência Social, uma entidade estatal do Governo Getúlio Vargas. Paralelamente, foi fundada a Sociedade Brasileira de Alimentação - SBA, primeira entidade civil, formada pelos profissionais da nutrição, com o objetivo de "colaborar com as autoridades públicas no estudo e solução dos problemas que, direta ou indiretamente, se relacionam com os interesses da alimentação nacional" (CASTRO, 1977). 
O Serviço de Alimentação da Previdência Social, o SAPS* , como popularmente ficou conhecido, era encarregado de fornecer alimentação aos trabalhadores segurados pelos Institutos de Aposentadoria e Pensão, eixo dorsal da política previdenciária, que cobria os empregos na indústria, no comércio, na estiva, no setor de transportes e cargas e no sistema bancário. Além da obrigatoriedade de instalação de refeitório em empresas com mais de 500 empregados, o SAPS criou restaurantes populares e conferiu importância relevante à educação alimentar.

A Sociedade Brasileira de Alimentação participou ativamente, através de grupo de intelectuais liderados por Josué de Castro, da criação do SAPS, encontrando neste órgão, apoio institucional, necessário na execução de políticas e de pesquisa em nutrição. Esse mesmo grupo organizava o saber da nutrição formando um paradigma sólido e hegemônico, que servia de referencial na orientação de intervenção pública.

O SAPS foi o primeiro e, durante muito tempo, o maior exemplo da aplicação social da ciência da nutrição, constituindo-se em legítimo representante de "política de alimentação", inaugurada em 40. Foi também, a matriz de um grupo de estudiosos da nutrição de importância na história do saber no Brasil, onde se estruturou uma "escola" e centro de pesquisa e reflexão liderada por Josué de Castro e se organizou uma grande equipe em torno de Dante Costa. A Sociedade Brasileira de Alimentação seguia junto ao SAPS, tendo sete Comissões de Estudos voltados para os temas: Medicina e Higiene, Biologia, Economia, Agronomia, Bromatologia, Estudos Sociais e Etnografia (COIMBRA e col., 1982).

Em 1945 instituiu-se a Comissão Nacional de Alimentação - CNA, regulamentada somente em 1951, como “órgão incumbido de assistir o Governo na formulação da política

\footnotetext{
• SAPS - Serviço de Alimentação da Previdência Social
} 
nacional de alimentação, coordenando para este fim os vários órgãos da administração pública” (CASTRO, 1977).

A política do governo Vargas direcionou-se, inicialmente, aos interesses da classe trabalhadora urbana e a partir de 1950, instalam-se vários programas de alimentação no país.

O Comitê Nacional da FAO, liderado por Josué de Castro, traçou o $1^{\circ}$ Plano Nacional de Alimentação para o Brasil e o apresentou na $3^{\circ}$ Conferência Latinoamericana de Nutrição, em 1953, enfatizando o grupo materno-infantil e mencionando o escolar e o trabalhador. Desde então, até a década de 70, a história dos programas de suplementação alimentar se confunde, praticamente, com a história da merenda escolar.

Já na década de 40, existiam algumas ações, desencadeadas pelo Serviço de Alimentação e Previdência Social-SAPS, dirigidas às crianças, como "o desjejum dos filhos dos operários", "o copo de leite escolar" e as "sopas escolares" (ROSENBURG, 1972). Dante Costa, destacado nutrólogo brasileiro, em palestra de encerramento da Semana da Criança, em 1946, disse considerar a escola um local de combate à desnutrição infantil, recomendando para isso, a utilização de três medidas: o desjejum, a merenda e o almoço escolares (COSTA, 1950).

O desjejum escolar foi implantado em 1925 na Noruega, depois na Rússia, Chile, Argentina. No Brasil, Dante Costa, chefe da Seção Técnica do SAPS, implantou, em 1942, o desjejum escolar que era servido das 6:30 às 7:30 da manhã. O desjejum consistia de um sanduíche de carne, de galinha, ovo ou queijo, um copo de leite e uma fruta; mais detalhadamente: $250 \mathrm{~g}$ de leite, $50 \mathrm{~g}$ de pão a $20 \%$ de farinha integral, $3 \mathrm{~g}$ de manteiga fresca, $40 \mathrm{~g}$ de queijo, $15 \mathrm{~g}$ de açúcar e $200 \mathrm{~g}$ de suco de laranja fresco, totalizando de 413 a 480 Calorias. Quanto à composição da merenda escolar, Dante Costa recomendava que 
fosse constituída de preferência de alimentos sólidos contendo também leite e sucos de frutas e respeitasse os hábitos regionais. $\mathrm{Na}$ impossibilidade de fornecimento dessa merenda por restrição econômica, aconselhava priorizar o copo de leite e considerava a sopa, como merenda única, a pior solução, servindo apenas de caráter demagógico.

Em 1953, quatorze dos vinte e cinco estados brasileiros tinham programas de almoços, subvencionados pelo governos locais, dirigidos a trabalhadores, enquanto $10 \%$ dos estudantes das escolas primárias se beneficiavam da alimentação escolar (OFICINA SANITÁRIA PANAMERICANA, 1954).

Constam das recomendações da $3^{\mathrm{a}}$ Conferência citada anteriormente: ampliação da alimentação escolar; a utilização do programa como veículo da educação sanitária na mudança de hábitos alimentares; a utilização, "a longo prazo", de alimentos locais e esforços para fabricação de alimentos e misturas de alimentos baratos.

Nessa oportunidade, o UNICEF e a FAO se colocaram à disposição para ajudar os governos a estabelecer projetos transformadores de produtos de valor especial para a alimentação infantil, tais como, a farinha de pescado e derivados de soja. Havia interesse da Organização das Nações Unidas-ONU em tornar o Brasil importante beneficiário do programa de doação de alimentos.

Na história da política nacional da alimentação, o que tivemos no Brasil, foi a apropriação pelo governo federal das experiências dos governos estaduais e municipais, bem como das próprias escolas através das Caixas, que custearam programas de merenda escolar desde o começo deste século.

Em São Paulo, as iniciativas na área de alimentação escolar se originaram das Caixas. O programa estadual começou em 1945, sob a responsabilidade da Diretoria do Serviço de Saúde Escolar, quando fornecia recursos financeiros a quinze escolas. Em 1946 
o número de escolas passou a 42, chegando-se a 26.700 alunos atendidos, dos quais 1.778 gratuitamente. Em 1947, criou-se a Seção de Nutrição do Serviço de Saúde Escolar para administrar um programa maior, atingindo 82 escolas, das quais 36 recebiam "Sopa" e 46 , merendas. Eram, então, 45.000 alunos servidos, 15.000 gratuitamente. Até uma nova equipe foi contratada, "nutricionistas diplomadas pela Faculdade de Higiene e Saúde Pública da Universidade de São Paulo, sob a direção de um médico especializado”. Esse sucesso se deveu a ampliação de recursos com o apoio da Legião Brasileira de Assistência, o SESI e inúmeras indústrias (COIMBRA e col., 1982).

A partir de 1948, surge a tendência da ultrapassagem do número das merendas gratuitas sobre as vendidas. Nos relatórios há pouco sobre a composição das merendas. O máximo que se pode saber é que existiam, desde 1951, sete padrões dessas refeições: sopa; sopa e lanche sólido; sopa e lanche líquido; lanche sólido; lanche líquido; lanche misto; especial. É provável que lanche líquido fosse apenas o copo de leite e lanche sólido fosse o sanduíche.

Nos finais de 1951, meses depois que o grupo de Castro tomou efetivamente postos na Comissão Nacional de Alimentação (CNA*), por sugestão de alguns especialistas americanos, entre eles Norman Jolliffe, foi planejada uma viagem de aperfeiçoamento e treinamento de técnicos aos Estados Unidos. O objetivo principal era uma especialização em métodos de inquéritos nutricionais e o escolhido por Josué de Castro, para realizá-la foi o nutrólogo Walter Santos, a fim de que pudesse coordenar um inquérito na Amazônia.

Feita no primeiro semestre de 1952 , essa viagem teve grande importância para a proposta do Programa Nacional de Merenda Escolar. Ao voltar, Walter Santos trazia um

* CNA - Comissão Nacional de Alimentação 
modelo bem concreto sobre como formular um programa com esse intuito, que características organizacionais deveria ter, quais as rotinas de operação, acompanhamento e controle. Mas foi somente em 1954 que o UNICEF autorizou a distribuição de leite em pó para escolares, viabilizando a implantação do projeto (COIMBRA e col., 1982).

A regulamentação da Merenda Escolar, em nível nacional, iniciada através de portarias do Ministério da Educação e Saúde, já na década de 40, é então, incrementada através da Campanha Nacional de Merenda Escolar, instituída em março de 1955, pelo Decreto Federal n 37.106/55 (ANEXO II) e modificada pelo Decreto Federal no 39007 de 11/4/56.

Esse decreto, ao instituir a Campanha Nacional da Merenda Escolar-CNME**, regulamentando as Portarias já existentes do Ministério da Educação e Saúde, define as atribuições desse órgão em três ações: incentivar por todos os meios ao seu alcance, técnicos e financeiros, os empreendimentos públicos ou particulares que se destinavam a facilitar a alimentação do escolar; estudar e adotar providências destinadas à melhoria do valor nutritivo da merenda escolar e ao barateamento dos produtos e promover medidas para aquisição desses produtos nas fontes ou mediante convênios com entidades internacionais. Era preciso cuidar das proteínas e vitaminas, bem como "resgatar os pobres das trevas da ignorância nutricional". Para isso, eram "doados" leite e mais tarde trigo laminado e trigo bulgor, excedentes da produção dos Estados Unidos e Canadá.

Surge, em 1954, a 1" edição da "Cartilha da Merenda Escolar" onde Josué de Castro escreve a introdução e inclui, no plano de trabalho para elevar os níveis de nutrição do país, o Programa Nacional de Merenda Escolar, como elemento essencial para a luta contra a fome e subnutrição. O estabelecimento desse Programa, segundo ele, permitiria

\footnotetext{
"* CNME - Campanha Nacional de Merenda Escolar.,
} 
racionalizar os programas de merenda escolar já existentes e estendê-los a todo o país, dando-lhes orientação técnica e assistência econômica. Além da suplementação alimentar, a merenda serviria para o desenvolvimento de atividades educacionais (CASTRO, 1954).

Em 1955, após o Decreto de Instituição da Campanha, foi distribuída a $2^{\mathbf{a}}$ edição dessa Cartilha, informando que naquele ano o programa tinha atendido perto de 800.000 escolares através de convênios firmados, pelo Ministério da Educação e Cultura, com governos estaduais e municipais. Nessa mesma publicação são relacionados os objetivos da merenda escolar e há extensa orientação sobre os alimentos a ela destinados, quanto aos fatores que deveriam ser considerados para a seleção dos mesmos (valor nutritivo, preço, aceitabilidade e facilidade de preparos), sugestões de preparo de mingaus, sopas, doces e sanduíches e instruções para a determinação do peso e da altura das crianças, cujos resultados deveriam ser interpretados pelas professoras e encaminhados aos pais, com as orientações necessárias (SANTOS \& PAES, 1956).

O prefácio da terceira edição dessa cartilha, escrito pelo Superintendente da CNAE, em 1959, publicado em espanhol, pela Agência para o Desenvolvimento Internacional (AID*) do Departamento de Estado dos Estados Unidos da América, para ser distribuída no Programa Aliança para o Progresso, revela a colaboração do Fundo Internacional de Socorro à Infância (UNICEF), o que permitiu a ampliação rápida do programa para dois milhões de crianças (SANTOS \& PAES, 1963); desde 1951, o Brasil passou a ter o maior programa de suplementação alimentar latino-americano apoiado pelo UNICEF, fornecendo leite em pó, margarina e cápsulas de vitaminas à crianças, nutrizes e gestantes, a um custo de US\$230.000,00 (COIMBRA e col., 1982).

\footnotetext{
AID - Agency for International Development, também conhecida como USAID/United States Agency for International Development
} 
Além do UNICEF, em seus primeiros anos de existência, a CNME recebeu volumes crescentes de alimentos da ONU e da Commodit Credit Corporation (CCC ${ }^{*}$, agência do governo norte americano, responsável pela política de estoques e preços minimos agricolas de seu país (TORRES FILHO e CARVALHO, 1989). O valor global das mercadorias fornecidas pelo UNICEF seria de US\$ $215.000,00$ e o governo brasileiro se obrigava a complementá-lo, com dotações significativas, destinadas à aquisição de gêneros alimentícios de alto valor nutritivo, a serem utilizados em conjunto com o leite doado. Marca-se aí o início dos "formulados" (COIMBRA e col., 1982). Entende-se como formulados, produtos novos para os quais não há hábito de consumo e uma demanda estabelecida; são produtos que incorporam insumos novos, procedimentos mais sofisticados, preparados cientificamente, com equilíbrio de nutrientes mais premeditado (CASTRO, 1985,).

As indústrias que participaram das primeiras concorrências, ainda em 1954, eram firmas pequenas nacionais. A maior delas foi a INPAR, "Indústria de Produtos Alimentícios Racionais" que venceu as concorrências no Ministério de Educação e Cultura-MEC"* e era a indicada pela superintedência da CNME aos representantes regionais, a fim de que levassem a sugestão às Secretarias de Educação, responsáveis pelas compras (COIMBRA e col., 1982).

Os "alimentos racionais" eram principalmente farinhas de cereais e leguminosas, como o milho, o trigo, o arroz e a soja. Dava-se preferência àquelas às quais eram adicionados minerais e vitaminas e que estivessem prontas para uso, de cozimento rápido. A composição delas deveria conter: $10 \%$ de proteínas (sendo $2 \%$ de origem animal) $18 \%$ de cálcio, $1 \mathrm{mg} \%$ de tiamina, $600 \mathrm{mcg} \%$ de riboflavina, $8 \mathrm{mg} \%$ de niacina, 12000 Unidades

\footnotetext{
" CCC - Commodit Credit Corporation

" MEC - Ministério da Educação e Cultura
} 
Internacionais de Vitamina A e 12000 Unidades Internacionais de vitamina $\mathrm{D}_{2}$ (COIMBRA e col., 1982). A compra desses gêneros de complementação do leite, dependia essencialmente de quem era o superintendente e qual sua posição face aos formulados. Note-se que esse cargo não era ocupado necessariamente por técnico em nutrição, mas por indicação política.

A grande sustentação de Campanha era o Governo Federal que aumentava, ano a ano, as dotações. O Decreto 40052, de 1/10/56 criou o Fundo Especial para custear as despesas da Campanha, sendo formado por contribuições da união, estados e municípios e as de convênios. Foi ao mesmo tempo, um passo importante na institucionalização do programa e um poderoso instrumento de centralização de poderes do Superintendente.

Verifica-se um importante salto institucional nesse período (1956 a 1958) com mais pessoal, mais recursos, mais presença e visibilidade. Quanto à distribuição de merenda aos escolares, não há quase informações consistentes sobre o atendimento que prestava. As fontes são contraditórias, sendo que os relatórios da CNME descrevem apenas aspectos acessórios e alguns dados quantitativos como números de escolas, de municípios atendidos e números de merendas servidas, e mesmo esses dados eram desencontrados. Nesses relatórios, o número de escolares atendidos pela CNME chega a 1.400 .000 em 1958, no Brasil. Em 1960, o Relatório do MEC apontava 2.572.426 escolares, de 19.891 escolas, em 1661 municípios atendidos.

Nessa fase o UNICEF estava retirando, ano a ano, a sua participação e a Commodit Credit Corporation se mostrava cada vez mais resistente em vender o leite em pó ao Brasil, sob o argumento da escassez. Surgem então, em 1962, os programas da Agência para Desenvolvimento Internacional (AID) e dos Alimentos para a Paz. 
O período de 1961 a 1964 se configura como o mais nebuloso, instável e perturbado da história da CNME. Houve muitas mudanças sucessivas de superintendentes, no total de nove. Interrompeu-se a participação do UNICEF e entra a participação da USAID* . Em $1^{\circ}$ de dezembro de 1961 se fez a primeira autorização para transferência de gêneros alimentícios do programa da USAID. O leite deveria vir, segundo o acordo firmado, em embalagens que tivessem legiveis os dizeres: "Leite em pó fornecido pelo povo dos Estados Unidos da América e distribuído pelo Governo Brasileiro". Começam as remessas de leite em 1962 e a USAID se torna exclusiva fornecedora, deslocando o UNICEF. Depois começa a se retrair e, no final de 63 e início de 64, não autoriza nenhuma entrega devido a instabilidade política brasileira. Após abril de 64 , as quantidades de alimentos autorizadas para o Brasil foram de 17.500 toneladas.

O periodo de 1964 a 1972, que cobriu os dois primeiros governos militares e parte do terceiro, caracterizou-se por profundas alterações na política de alimentação escolar, na sua concepção, no fomento da Campanha, na organização interna e no alcance geográfico. O Superintendente e seu corpo de auxiliares, todos militares, permaneceram em seus cargos durante todo o tempo; houve a presença maciça do "Programa Alimentos para a Paz" e do "Programa Mundial de Alimentos", fornecendo quase a totalidade dos gêneros.

A Campanha adquire dimensão nacional, sendo um dos programas sociais que mais longe, geograficamente, marcam a presença do Estado, como agente de políticas sociais, embora este fato acabe por contribuir com as desigualdades e discriminações.

Foram estabelecidas, nesse período, previsões de atendimento entre 4 a 7 milhões de escolares, durante oito meses letivos (176 dias) com uma quantidade de $33 \mathrm{~g}$ de leite em pó per capita. Percebendo a necessidade de comunicar-se com os diversos setores da

\footnotetext{
* USAID - United States Agency for Intemational Development
} 
sociedade, para contribuir com o esforço de legitimação do Regime de 31 de março, a Campanha estabeleceu estratégia de divulgação de suas atividades: ressurgiu o Boletim da CNME, com periodicidade trimestral, foram organizadas exposições, sendo a maior, por ocasião do $10^{\circ}$ aniversário; retomou-se a reunião anual de representantes regionais. Foram consolidadas as alianças internacionais com a USAID e com o Programa Mundial de Alimentos (COIMBRA e col., 1982).

Em junho de 1965, numa promoção conjunta USAID/CNME realizou-se, no Rio de Janeiro, o III Seminário Interamericano de Alimentação Infantil, com a participação de diversas entidades públicas e filantrópicas. Discutiu-se o andamento de vários programas em dezessete países da América Latina. Durante o evento, foram referidas as experiências de combinação de farinha de milho, trigo e soja no cardápio das merendas escolares, como "novas fórmulas de alimentos". Representantes das indústrias americanas, a convite da USAID, falaram sobre o interesse do seu governo em apoiar as indústrias de alimentação infantil e das possibilidades mercadológicas oferecidas pelos programas de alimentação escolar (COIMBRA e col., 1982).

Neste período, concretizou-se um projeto que vinha sendo negociado há alguns anos. Foram doadas duas máquinas de fazer massa de farinha de trigo, pela Federação Americana de Moageiros, instaladas em Guarulhos, São Paulo. Outras doações foram feitas, pelo estado norte-americano de Maryland, para outra fábrica em Niterói.

É então lançado o Programa de Almoço Escolar, concebido como uma refeição completa, capaz de fornecer todos os nutrientes necessários à alimentação do escolar, para o qual o leite e farináceos, doados do exterior, receberiam uma complementação de verduras e alimentos ricos em proteínas, fornecidos pelos estados e comunidades locais. A Campanha passa a se denominar Campanha Nacional de Alimentação Escolar - CNAE, 
(Decreto Fed. 56886/65) abrangendo, além da faixa do $1^{\circ}$ grau, os estudantes dos cursos supletivos, parte do secundário e parte dos pré-escolares. Os dados de cobertura declarados pelo Superintendente, para o ano de 1965, são pouco claros; o número de refeições servidas para os 3500 municípios, não seriam suficientes para 51 dias letivos; as remessas americanas, que totalizaram 43.186 toneladas, seriam insuficientes para fornecer 30 gramas, por almoço, por dia (COIMBRA e col., 1982, NEVES, 1965).

A doação de alimentos de órgãos internacionais foi mantida durante a vigência do acordo com esses organismos e o governo brasileiro teve que assumir, com o orçamento federal, a compra de produtos destinados aos programas de suplementação alimentar. Isto determinou a introdução de alimentos formulados - (sopas, mingaus, milk-shakes, etc). O Programa de Merenda Escolar transformou-se em importante demandante da recém constituída indústria nacional de alimentos formulados.

Em 1966, o governo norte-americano anunciou mudanças profundas na política de ajuda externa; já não havia os enormes estoques excedentes e a produção agrícola precisava expandir-se; portanto os países pobres deviam buscar formas de "auto-ajuda", com a colaboração das universidades, da indústria privada e dos técnicos norte-americanos. As compras de alimentos nos Estados Unidos teriam que ser pagas em dólares. Seriam abertas novas linhas de crédito, aos países que quisessem adquirir máquinas, fertilizantes e outros insumos.

Os contatos da CNAE com as indústrias já não eram recentes, mas o estreitamento dessas relações foi intensificado na reunião do Panamá, sob os auspícios da USAID, a "IV Conferência Interamericana sobre Má Nutrição". Além dos participantes da Campanha, a delegação brasileira contou com executivos das indústrias de laticínios e de alimentação. 
O propósito dessa participação foi o de motivar a indústria para a produção de alimentos de alto valor nutritivo, principalmente protéico, pois era a maior carência na dieta brasileira.

A opção por produtos formulados se apoiou na ideologia nutricional da época (década 60). Estudos e publicações internacionais indicavam que a desnutrição estaria associada a hábitos alimentares em desacordo com as necessidades biológicas do organismo humano (RITCHIE, 1968). As políticas dos governos, especialmente nos países pobres, deveriam utilizar, preferencialmente, alimentos enriquecidos. Esta versão da questão alimentar serviu de base para uma estratégia mercadológica da indústria de alimentos em nível internacional. Como vantagem dos produtos formulados apontavam-se o aspecto operacional, a regularidade da oferta, a baixa perecibilidade, a facilidade no transporte e no armazenamento e a simplicidade no preparo (COIMBRA e col, 1982).

Uma publicação que circulou no Brasil nessa época, com periodicidade bimensal, foi a revista intitulada "Produtos e Nutrição: Funções da nutrição e seus últimos progressos", cujo conselho científico consultivo contava com expoentes do campo da nutrição. É interessante observar o conteúdo dos assuntos tratados; por exemplo, um exemplar de 1970, inclui duas pesquisas, sendo uma, sobre o diagnóstico da situação alimentar no Brasil, feito pela Comissão Nacional de Alimentação - CNA.

Esse trabalho conclui que em todas as regiões brasileiras existiam deficiências de consumo, incidindo nos grupos populacionais de poder aquisitivo reduzido; que existia ignorância sobre o valor dos alimentos e as necessidades orgânicas; que o ciclo vicioso do subdesenvolvimento, composto pela ignorância, aliada aos maus hábitos de consumo de alimentos pobres em valor nutritivo, somava-se à ausência de saneamento básico, completando o cenário da subnutrição e infeç̧ão e, gerando inferioridade física, doença, pobreza e morte. Esse mesmo artigo, afirmava que os programas de alimentação no 
passado eram divorciados dos de nutrição, resultando num consumo de menor valor nutritivo mas que essa tendência havia se modificado, felizmente. Alertava ainda para o perigo que representa a falta de proteínas completas na fase de crescimento até 6 anos de idade, que podem tornar indivíduos "mutilados mentais".

O outro artigo contido na mesma revista, intitulava-se "Pó de carne" - alimento obtido do aproveitamento de gado de má qualidade, afirmando ser produto que poderia ser usado como proteína pura ou adicionado a mandioca, milho ou batata. Mencionava que o Ministério da Saúde de Tanganica verificou que escolares que recebiam dieta enriquecida com o "pó de carne" alcançavam altura maior e eram mais sadias (PRODUTOS E NUT., 1970).

No final de 1966, a Revista da CNAE reconhece que a Campanha se expandiu bastante em termos estruturais, mas a ambiciosa meta de atender a 11 milhões de escolares, até o final daquele ano, estava distante demais. No Relatório Anual de 1967, a CNAE revela ter atendido, em 1966, 7.046.731 crianças, com média anual de atendimento de 50 dias, $28 \%$ da meta prevista.

Em 1967, durante o governo de Costa e Silva, é extinto o SAPS. Prossegue a implementação do setor industrial, com a instalação de máquinas da homogeneizar alimentos, na Baixada Fluminense,doadas pela Aliança para o Progresso. A Campanha possuía, nesse ano, 78 setores regionais. Publica-se o primeiro relatório anual, intitulado "Alimentação Escolar no Brasil", onde não existem especificações quanto ao tipo e qualidade dos alimentos servidos, qual a composição nutricional da merenda ou do almoço escolar etc (COIMBRA e col., 1982).

Em 1968, houve um novo impulso da CNAE; há ampliação de seus laços com a indústria e ela torna-se independente até mesmo do estado. Passa a ter 120 setores 
regionais; nesse ano sai a primeira edição da publicação "Instruções para a instituição de setor regional da CNAE"; a 2a edição de 3000 exemplares é editada em 1971 (MEC, 1971). As relações com a USAID prosseguem estreitas: envia para a Campanha 25000 toneladas de alimentos, promove viagem de estudos aos Estados Unidos, para um grupo de nove brasileiros, enquanto o setor industrial foi presenteado com máquinas para o aproveitamento do preparado $\mathrm{CSM}^{*}$ (corn,soy milk) (COIMBRA e col., 1982). Também nessa época, a CNAE teve que receber do Ministério do Planejamento, duas mil máquinas, que as comprou da Dinamarca, como parte de acordo entre os dois países.

Essas máquinas, foram chamadas de vacas mecânicas e deveriam ser utilizadas para a reconstituição do leite em pó (CSM), que apresentava dificuldades nesse processo; porém para a instalação das mesmas, eram necessárias instalações elétricas e hidráulicas especiais e, ainda, a capacidade de produção era muito superior à demanda, tornando-as anti-econômicas (COIMBRA e col., 1982).

Ainda em 1968, o relacionamento da CNAE com as indústrias foi mais intensificado através da formação da Associação Brasileira de Alimentação Escolar ABAE. Dois fatos concorreram para solidificar essa idéia lançada em 1966: o primeiro, foi a produção da soja em larga escala, destinada à exportação e utilizada como estratégia comercial através da introdução de produtos derivados, no programa de merenda escolar; o segundo, foi a realização do II Simpósio Brasileiro de Alimentação e Nutrição, organizado pela Universidade de Pernambuco, dirigido pelo Prof. Nelson Chaves e patrocinado pelo CNPq* e ABIA** (Associação Brasileira das Indústrias de Alimentação). Os assuntos, nesse encontro, variaram muito, mas a ênfase foi dada aos problemas da carência protéica da

\footnotetext{
- CSM - (farinha distribuida pela USAID, composta de $75 \%$ de fubá, $5 \%$ de soja e $20 \%$ de leite destinado.

- CNPq - Conselho Nacional Desenvolvimento Cientifico e Tecnológico

** ABIA - Associação Brasileira das Indústrias de Alimentação
} 
população brasileira e de como a soja e seus derivados poderiam resolvê-la (COIMBRA e col., 1982).

A ação institucional da Campanha, no período de 1967 a 1972, observada nos relatórios, aponta para recursos limitados e desigualmente distribuídos. O paradigma nutricional sofreu transformação nesse período, embora nada de novo tenha sugerido. Segundo análise de Coimbra, as idéias da nutrição, desde a década de 30 , provinham de duas vertentes: de um lado, das universidades e dos centros de pesquisa, que se caracterizavam por dar um tratamento experimental e laboratorial aos problemas da alimentação humana; do outro, das primeiras agências de alimentação, como o SAPS, onde a prioridade do ideário da alimentação voltava-se para preocupações e interrogações que transcendiam à "ciência pura". A segunda vertente foi a que melhor se ligou ao estado, devido ao peso político de Josué de Castro e de Dante Costa e da forma como definiam o problema alimentar brasileiro. Segundo suas idéias, a alimentação era problematizada como algo essencialmente social, que dependia de um leque de causas que obrigavam a pensar a sociedade como um todo. A vertente laboratorial era essencialmente técnica, preocupada com sua "ciência", e não com a sociedade.

Com o regime implantado em 1964 , as idéias problematizadoras, implantadas e conduzidas por Josué de Castro, são descartadas e, no vazio criado, cada vez mais a nutrição e a desnutrição se tornaram problemas "técnicos", que deviam ser resolvidos tecnicamente. Este enfoque não ocorreu somente com a ciência da nutrição.

Na concepção dessa época, ao mesmo tempo que os profissionais continuavam a reiterar a relação entre a sociedade e a alimentação, se recusavam a discutir aquilo que ela definia como preocupações estranhas à sua disciplina. A alimentação fica entendida como 
um processo eminentemente fisiológico, passado no interior do organismo e separado do componente social.

“A década de 70 merece destaque no que diz respeito à produção do conhecimento no campo da epidemiologia social e no de políticas públicas da saúde e nutrição. A epidemiologia social universaliza a abordagem da questão saúde, identificando problemas setoriais com a qualidade de vida da população" (BREILH, 1981). A saúde consolida o pensamento crítico que transforma as maneiras tradicionais de pensar a saúde pública $\mathrm{e}$ busca novos paradigmas que incorporam o social (CARVALHEIRO, 1991). Nesse quadro, volta-se a considerar a necessidade de enfrentar o problema da desnutrição corrigindo suas causas básicas; estimula-se o planejamento de programas multi-setoriais de diagnóstico e de ações.

A reunião especial de Ministros da Saúde das Américas, realizada em 1972, difundiu a idéia de se criar um sistema de assessoramento para os países latino-americanos com o objetivo de apoiá-los, técnica e politicamente, em seu compromisso de combater a desnutrição. Isto resultou na criação do Projeto Interagencial de Promoção de Políticas Nacionais de Alimentação e Nutrição - PIA/PNAN, contando com a participação da OPS /OMS, FAO, UNICEF e CEPAL * - (OMS, 1972).

Estudiosos de nutrição apontavam a necessidade de se retornar à questão da correção do problema nutricional com programas efetivos do governo, multi-setoriais, que implicassem em alterações nas causas básicas do modelo de determinação da desnutrição energético-proteica.

Estimulou-se o surgimento de projetos interdisciplinares de diagnóstico e ação, que contemplassem os aspectos da disponibilidade de alimentos, quantitativos e

\footnotetext{
- CEPAL - Comissão de Econômica para América Latina e Caribe
} 
qualitativos, renda familiar, fatores de saúde agravantes ou precipitantes (BEHAR, 1991). $\mathrm{Na}$ década de 70 , a produção científica de nutrição concentra-se no estudo do perfil nutricional das populações e seus determinantes.

No ano de 1972 o governo brasileiro criou o Instituto Nacional de Alimentação e Nutrição - INAN** (Decreto n 5829 de 30/11/72), estabelecendo o I Programa Nacional de Alimentação e Nutrição - I PRONAN, que foi mal administrado e pouco executado (COIMBRA, 1985).

A criação do INAN foi defendida por vários setores públicos e privados. Houve a designação de um grupo de estudos para propor sugestões sobre o órgão, onde participou a elite da Campanha, que tinha como perspectiva a instituição CNAE ampliada e estabilizada. O INAN, vinculado ao Ministério da Saúde, deveria absorver as funções da CNAE, deslocando as decisões do Programa de Merenda Escolar para fora da esfera da Educação. Segundo análise de Coimbra, os dirigentes da Campanha movimentaram-se para impedir essa incorporação, trazendo como resultado, de um lado, o adiamento da solução para o impasse orgânico e, de outro, o enfraquecimento do INAN (COIMBRA e col., 1982).

No período de 1973 a 1979, houve mudanças institucionais internas na CNAE que permitiram a compra de grande parte de alimentos pelas coordenações regionais, como açúcar, farinhas e óleos, enquanto a Superintendência comprava os alimentos industrializados e enriquecidos.

Em julho de 1973, no II Congresso Brasileiro de Saúde Escolar, é lançada a “Caracterização Operacional da Merenda Escolar Brasileira” ou, como ficou chamada, a COMEB $^{*}$. A COMEB tratava de normas para licitações de alimentos para a Campanha,

\footnotetext{
** INAN - Instituto Nacional de Alimentação e Nutrição

" COMEB - Caracterização Operacional da Merenda Escolar Brasileira.
} 
disciplinava o controle microbiológico dos gêneros a serem distribuídos, indicava os "métodos científicos da administração regional" e definia a metodologia de aferição do NPU** (Net Protein Utilization) (COIMBRA e col., 1982)

Os aspectos da merenda escolar, que deveriam ser considerados, segundo lideranças da CNAE, giravam em torno de uma triangulação: valor nutritivo, palatabilidade e custo. No entanto, a importância era concentrada no valor nutritivo, sendo a aceitabilidade e custo, questões secundárias. $\mathrm{O}$ valor nutritivo mínimo que o programa buscava para a merenda escolar brasileira, no biênio 1973-1974, era: VCT $^{*}$ de 350 Kcal, $11,5 \mathrm{~g}$ de proteínas, $7 \mathrm{~g}$ de proteína de alto valor biológico, $650 \mathrm{UI}$ de vitamina A, 0,2 $\mathrm{mg}$ de vitamina B1, 0,2 mg de Vitamina B2, 2,5 mg de vitamina B6 e $2 \mathrm{mg}$ de ferro. Coimbra compara esses valores, com os exigidos pela Campanha em 1956, para as farinhas enriquecidas de cereais, que comprava para complementar o leite recebido pelo UNICEF. Embora o refinamento do índice NDpCal \%"* não fosse empregado naquela época, os requerimentos exigidos eram 5 a 20 vezes maiores do que os da COMEB (COIMBRA e col., 1982). Essa proposta da COMEB foi apresentada no I Encontro da CNAE/MEC com Indústrias de Alimentação, realizado em 1973, em Brasília. No mesmo ano de 1973, o Decreto 72034/73 acrescentou aos objetivos da Merenda Escolar, diminuir os índices de repetência e evasão, minimizar o problema da desnutrição e melhorar o rendimento escolar.

Nesse período, os principais alimentos comprados pela CNAE foram: paçoca de amendoim, farinha láctea sabor caramelo, sopa creme flor, condilac sabor côco, sopa de feijão com macarrão, creme de cereais com legumes, sopa creme de milho com PTS (proteína texturizada de soja).

\footnotetext{
** NPU - Net Protein Utilization = Nitrogênio retido/Nitrogênio ingerido (WHO, 1965 p.43)

- VCT - Valor Calórico Total

- NDpCal \% - Expressa a porcentagem de calorias derivadas das proteínas, corrigidas pela eficiência da utilização das proteínas NPU. (WHO, 1965 p. 45)
} 
Além dessas compras, as coordenações regionais, com recursos estaduais ou através de repasse da Superintendência, também faziam suas licitações, principalmente na região sudeste. Estas deveriam gastar, preferencialmente, com alimentos "in natura", mas, freqüentemente, aplicavam em formulados. Os mais comprados eram cereais, carnes, óleo, biscoitos, balas, doces, mingaus e farinhas.

Assim, a Campanha substituiu os gêneros que recebia da USAID e outros, por produtos elaborados por um sub-setor industrial que a Campanha encorajou e sustentou.

Em 1975 foi traçado o II PRONAN, que abordou a desnutrição energéticoproteica como problema social, determinado pela desequilibrada distribuição de renda, conseqüência da política econômica adotada (ARRUDA, 1982). O II PRONAN estabeleceu três linhas básicas de ação: a suplementação alimentar ao grupo maternoinfantil, escolares e trabalhadores; o estímulo e racionalização da produção de alimentos básicos e ações complementares de pesquisas, de capacitação e recursos humanos e de combate às carências específicas (INAN, 1975).

O II PRONAN, englobou o PNAE" que tinha como meta "proporcionar suplementação alimentar aos escolares do primeiro grau matriculados nos estabelecimentos de ensino público e aos pré-escolares, através do fornecimento de uma refeição de valor nutricional equivalente a $15 \%$ e até $30 \%$ das recomendações nutricionais diárias durante o ano letivo.

De 1973 a 1978, amplia-se o controle central através de mecanismos de acompanhamento implantados pela Superintendência da Campanha. Em contrapartida, foram delegadas às Representações Regionais as aquisições de gêneros, mediante a transferência de recursos, sendo reforçadas suas estruturas administrativas e físicas. Em

\footnotetext{
* PNAE - Programa Nacional de Alimentação Escolar
} 
1979, o relatório do Programa Nacional de Alimentação Escolar apontava atendimento a 3549 municípios e 14.003 .762 escolares.

Em 1973, acontece a Semana de Debates sobre Alimentação Escolar, na Câmara Municipal de São Paulo. Nessa oportunidade, o Diretor do Serviço de Saúde Escolar da Secretaria da Educação do Estado de São Paulo, afirmou em seu discurso, que a merenda deveria suprir $25 \%$ das necessidades nutricionais mínimas diárias da criança e propôs um cardápio semanal: leite com farinha "sojarroz"; leite com frutas; sopa de feijão com macarrão; leite com nescau; sopa de legumes com "sojarroz"; canjica com farinha de amendoim (TOLEDO, 1973).

Nesse mesmo evento, o Diretor do Departamento de Assistência Escolar da Secretaria de Educação e Cultura do município de São Paulo, apontou a desnutrição protéico-calórica como problema constante e permanente em nosso meio e esclareceu que a Prefeitura de São Paulo havia assumido a merenda escolar como uma alimentação supletiva, complementar à alimentação de casa, composta de alimento de alto valor nutritivo, de fácil digestão de modo a não interferir na refeição de casa. Os horários estabelecidos foram os afastados dos horários da refeição do domicílio. Atendia, na ocasião, 250 mil crianças. O Programa não se interrompia no recesso ou férias escolares. $O$ cardápio básico oferecia 341 calorias e $15 \mathrm{~g}$ de proteína por merenda. Alimentos fornecidos: leite com chocolate e açúcar; sanduíche; leite com farinha de amendoim ou outra farinha; sopa de legumes com fubá e farinha de soja, ou CSM (leite, fubá e soja) e ovo cozido; canjica; leite com enriquecedor e pão com patê (ROSENBURG, 1973).

Entre as recomendações finais dessa semana de Debates destacam-se: a necessidade de ampliação de estudos, pesquisas e inquéritos nutricionais e alimentares para se conhecer melhor os problemas existentes; a proposta do valor calórico da merenda não 
inferior a 375 calorias, com taxa protéica mínima de $12 \mathrm{~g}$ e a ênfase na educação alimentar (SOUZA, 1973).

Quanto aos campos do diagnóstico nutricional e da política de Saúde, nesse período, destacam-se dois episódios relevantes:

a) o Estudo Nacional de Despesa Familiar - ENDEF, realizado pela Fundação Instituto Brasileiro de Geografia e Estatística - IBGE, em 1974/75, por amostragem domiciliar, abrangendo 55000 domicílios em todo o país. Conforme dados desse trabalho, divulgados em 1977, somente $32,8 \%$ da população possuía uma dieta adequada em energia, apresentando diferenças regionais marcantes. Essa pesquisa foi um marco de referência fundamental para a avaliação da situação social do país (FUNDAÇÃO IBGE, 1977).

O ENDEF quebra o mito de que haveria séria carência de proteína no Brasil. Revelou que o brasileiro tem sobretudo desnutrição calórica. Mostrou que ricos e pobres consomem aproximadamente os mesmos alimentos, mas em quantidades diferentes.

A partir dessa concepção, oficializada pelo II PRONAN, os programas de distribuição de alimentos passam a ser vistos como instrumentos de redistribuição de renda e as compras institucionais dirigem-se ao pequeno produtor. Concluiu-se que as ações necessárias para prevenir a desnutrição coincidiam com as do plano geral de desenvolvimento social e econômico do país.

b) Em 1978 houve um fato importante para a política de saúde e nutrição: a Conferência Internacional Alma-Ata, com o objetivo de alcançar "saúde para todos no ano 2000", recomendava que as atividades de nutrição fossem 
incluídas nas ações básicas do programa de atenção primária de saúde. Esse programa, segundo planejamento estratégico, proposto nessa Conferência, deveria ter sua cobertura estendida à toda população, simplificando ações a nível primário, com apoio logístico e técnico de referência (OMS, 1978).

Enquanto se discutia o sistema de saúde, evidenciando-se a necessidade da participação da comunidade no diagnóstico e nas propostas de solução para esse setor, os programas verticais de suplementação alimentar se expandiram.

No período de 1976 a 1985 , no âmbito federal, estadual e municipal, ocorreu a multiplicidade de programas de suplementação alimentar, que se caracterizaram pela diversidade e superposição de objetivos, pela inconstância e descontinuidade e pela ausência de avaliação, sendo definidos por diferentes foros, comissões, conselhos, grupos de trabalhos, etc. Surgem diversos estudos que procuram analisar esses programas sob diferentes aspectos (STEFANINI, 1987).

Em São Paulo, em substituição ao Serviço de Saúde Escolar existente, é criado o Departamento de Assistência Escolar da Secretaria de Estado da Educação, ao qual subordina-se o Serviço de Nutrição, pela Lei 7510/76.

Em 1978, o Departamento de Assistência Escolar da Secretaria Municipal de Educação de São Paulo promoveu o I Curso de Saúde Escolar, cujo tema enfocado foi: "bases nutricionais da merenda escolar".

Nessa oportunidade, foram repassados o conceito, as características e a situação nutricional do escolar, bem como, a definição e as características da merenda escolar (CAVALCANTI, 1978). Ficou reforçado que havia necessidade de alimentação equilibrada, para atender às exigências nutricionais necessárias ao crescimento e desenvolvimento e à intensa atividade física da vida escolar; ressaltou-se a importância do 
intervalo de idades ( 7 a 14 anos) como o periodo em que o indivíduo reforça intensamente os hábitos fixados, os conhecimentos adquiridos em qualquer área, inclusive na de alimentação e nutrição, sendo que os valores e atividades firmados nessa etapa da vida influem decisivamente no comportamento alimentar do indivíduo. Daí resulta a atenção que se deve dispensar ao escolar, quanto às atividades educativas na área de saúde, alimentação e nutrição.

Ficou reafirmado, nesse curso, o objetivo geral do Programa de Merenda Escolar, de contribuir para melhorar as condições nutricionais e de saúde dos escolares e os específicos, de fornecer à criança alimentação suplementar e o de educar a criança na área de alimentação e nutrição. No documento onde ficou registrado esse evento, consta que a merenda escolar definida em 1971, pela Divisão de Estudos, Normas e Programas de Nutrição (DENPN) do Departamento de Saúde Escolar da SES, tinha como finalidade suprir, pelo menos, $25 \%$ das necessidades proteico-calóricas e de minerais do escolar, modificada, a partir do II PRONAN, para 15 a $30 \%$ das recomendações nutricionais diárias.

Aliás, já em 1973, o INAN, através do I PRONAN, propôs que a Merenda Escolar atendesse pelo menos $25 \%$ das necessidades nutricionais do escolar durante 140 dias do ano, e que fosse incluída no currículo de ensino do $1^{\circ}$ grau, disciplina específica de educação nutricional. Estas ações concorreriam para: melhorar os hábitos alimentares dos escolares; diminuir os índices de absenteísmo e deserção escolar; aumentar a capacidade de aprendizagem e o aproveitamento escolar e reduzir a prevalência da desnutrição do grupo assistido (INAN, 1973).

O potencial educativo da merenda Escolar foi reforçado mais tarde no capítulo “novos alimentos, velhos hábitos e o espaço para ações educativas", do livro O problema 
alimentar do Brasil. CASTRO e PELIANO (1985) dizem: "a hora é boa para se definir os espaços de uma nova concepção correta de educação alimentar. Não há que voltar a propôla como substitutivo de transformações estruturais. Mas sabemos tratar-se de um significativo instrumento adicional de apoio e complementação às intervenções na área alimentar. Em particular, cabe definir-lhe um papel maior na escola, lugar geométrico de formação de atitudes, hábitos e persuasões intelectuais”.

Em 1979, a Diretora da Divisão de Nutrição do Departamento de Assistência Escolar da Secretaria de Educação de São Paulo, em palestra proferida no "Encontro Técnico Científico de Alimentação", em São Paulo, insiste em considerar fundamental o aspecto da aceitação dos produtos destinados ao programa e não somente o aproveitamento em termos de PER* (quociente de eficiência protéica) e NPR ** (quociente da utilização real da proteina) (MORAES, 1981).

Em 1981, surgiu o Instituto Nacional de Alimentação Escolar - INAE* - em substituição à CNAE iniciada há 25 anos, responsável pelo PNAE e precursor da Fundação de Assistência ao Estudante - FAE** , criada em 1984.

O INAE foi criado através da Portaria Ministerial $\mathrm{n}^{\circ} 708$, de 22 de dezembro de 1981, com três diretrizes básicas: busca da eficiência, com destaque à descentralização de atividades para os estados e municípios, busca da eficácia com destaque ao tratamento científico a ser dado à alimentação escolar e, a terceira, a busca do envolvimento comunitário.

\footnotetext{
- PER - quociente de eficiência protéica

* NPR - quociente da utilização real da proteina

- INAE - Instituto Nacional de Alimentação Escolar

- FAE - Fundaçăo de Assistência ao Estudante
} 
Começam a ocorrer mudanças estruturais significativas. A regionalização do cardápio começa a tomar forma, sendo firmado convênio com a COBAL ${ }^{*}$ com vistas a melhorar a flexibilidade operacional e regionalizar as compras. O INAE atua em todos os estados brasileiros, através de convênios com as Secretarias da Educação, mantendo representação em cada um deles, tendo como objetivos principais:

- prestar cooperação técnica para a execução de atividades relativas ao PNAE;

- definir padrões nutricionais e operacionais a serem adotados na execução do programa;

- fornecer os gêneros alimentícios e

- supervisionar, analisar e avaliar em conjunto com as Secretarias os resultados da execução do programa.

Os anos 80 , se iniciaram com um quadro de crise que somava, à enorme dívida externa contraída na década anterior, a escassez do capital no mercado externo, a retração do comércio internacional e economias destroçadas por políticas recessivas de ajuste à crise (UGÁ, 1989). O Brasil, diferentemente de outros países da América Latina, não seguiu o caminho do ajuste a partir da crise do petróleo, em 1974. Optou por uma estratégia de crescimento com endividamento. Entramos na década de 80 com uma política de achatamento salarial, restrição ao crédito, aumento de taxa de juros, diminuição do investimento público, queda na produção, aumento do desemprego.

Os efeitos da crise sobre as políticas sociais determinaram a criação do fundo de arrecadação FINSOCIAL, em 1982, que era proveniente da taxação de $0,5 \%$ dos rendimentos brutos das empresas privadas e estatais.

\footnotetext{
* COBAL - Companhia Brasileira de Alimentos
} 
Os recursos do FINSOCIAL foram utilizados para implantação de vários programas de suplementação alimentar, sendo os mais abrangentes o PNAE e o Programa de Alimentação ao Trabalhador (PAT).

O INAE teve como meta para 1982 o fornecimento de duas refeições diárias; de 700/800 calorias que representam 30\% das necessidades energéticas da criança; para 1983 as metas foram proporcionar merenda a toda população pré-escolar, do $1^{\circ}$ e $2^{\circ}$ graus, num universo de 23 milhões de educandos e ampliar a assistência, através de programas de bolsas de manutenção e saúde escolar. Os produtos distribuídos variavam entre alimentos formulados e alimentos básicos de consumo tradicional.

Segundo as metas governamentais, o PNAE deveria garantir o atendimento a todos os alunos da Rede de Ensino, durante 180 dias letivos, estendendo-se ao período de férias. Entretanto, segundo CAMPINO (1985), a média de atendimento às crianças, nos primeiros anos da década de 80 , era de 130 dias por ano, a quantidade de merenda distribuída insuficiente e a qualidade inadequada. É reconhecida a necessidade de elevar o valor nutricional das refeições oferecidas e o número de dias de atendimento (PELIANO, 1992).

Com o surgimento da FAE - Fundação de Assistência ao Estudante, em 1984, consolida-se o papel das Secretarias Estaduais da Educação, como executoras do Programa de Merenda Escolar.

Essa fundação foi fruto da fusão do INAE com a FENAME - Fundação Nacional do Material Escolar. Todas as atividades de assistência ao estudante desenvolvidas pelo MEC, compreendendo a concessão de bolsas de estudo e crédito educativo, programa de merenda escolar e material didático, foram reunidas na FAE. 
Em meados da décadas de 80 o PNAE, no âmbito nacional, foi submetido a um processo de redefinição estratégica com os objetivos de regionalizar os cardápios, descentralizar o processo de compra, promover a articulação com a Secretaria Especial de Abastecimento e Preços e implantar o sistema de qualidade dos alimentos (BATISTA FILHO \& BARBOSA, 1985).

No Estado de São Paulo, o Departamento de Assistência Escolar da Secretaria de Educação, atendeu, em 1982, aproximadamente 3,6 milhões de alunos, em 18.423 escolas. Foi introduzido em 1981, o programa "férias na escola", com atividades de lazer e recebimento de três refeições, implantado em 317 escolas, contando com a participação de 1200 voluntários e 800 monitores remunerados.

Até 1983, o funcionamento do Programa de Merenda Escolar em São Paulo foi feito de forma centralizada no Departamento de Assistência ao Escolar da Secretaria de Estado da Educação, subsidiado, em parte, pelo PNAE do Ministério de Educação e Cultura. A partir desse ano, antecipando-se à iniciativa dos órgãos federais, o Governo do Estado de São Paulo deu início ao processo de descentralização do PME, através da Lei Estadual $\mathrm{n}^{\circ} 573 / 83$. Configurava-se como um processo gradativo, experimental e optativo para os municípios (FONSECA, 1988).

Em trabalho realizado pelo Núcleo de Políticas da UNICAMP, em 1983, em São Paulo participaram do processo de descentralização, 118 municípios com uma população de 970.960 crianças e, em 1989 já haviam 552 municípios participantes com 3.627.139 beneficiários (NUTTI, 1986).

Em 5/10/84, o Decreto Estadual 22.758, criou os Conselhos Municipais da Merenda Escolar, com a finalidade de orientar a política de aquisição, armazenamento, 
preparo e distribuição de produtos destinados à Merenda Escolar-DAE* . Em publicação do Departamento de Alimentação do Escolar são enunciadas as vantagens da municipalização da merenda escolar:

- permite a elaboração da merenda escolar, compatível com os hábitos alimentares dos escolares, através da dieta habitual da região;

- proporciona maior variedade de alimentos, especialmente os "in natura", aumentando as alternativas dos cardápios;

- incentiva a economia local ao adquirir alimentos na própria região;

- estimula a geração de empregos e

- reduz custo unitário da merenda escolar com a diminuição do custo dos transportes.

No início de 1988 o governo do Estado de São Paulo fez modificações no PME, instituindo o ciclo básico, formado pelo $1^{\circ}$ e $2^{\circ}$ anos do $1^{\circ}$ grau, e a jornada única para essas duas séries, devendo a criança permanecer um período de seis horas na escola. A Resolução 62 de 13/3/89, fixou para esses alunos de jornada única, o valor nutricional mínimo da merenda escolar a ser fornecido, em três refeições, de 720 Kcal e $22 \mathrm{~g}$ de proteína e NDpCal\% maior que 7. Nesse ano, $70 \%$ dos cardápios da merenda escolar de São Paulo eram compostos por produtos formulados.

Um estudo realizado em sete escolas estaduais da cidade de Piracicaba, São Paulo, para avaliar a contribuição da merenda oferecida aos escolares do ciclo básico da rede oficial de ensino, mostrou que a merenda contribui com aproximadamente $30 \%$ do total diário recomendado de energia, e com $100 \%$ das recomendações diárias de proteínas, para o grupo de 7 e 8 anos de idade. A contribuição da vitamina C, esteve em torno de $25 \%$ e a

\footnotetext{
•DAE - Departamento de Alimentação Escolar
} 
do ferro $16,3 \%$. Note-se que esse estudo analisou a merenda escolar fornecida às crianças do ciclo básico que estavam no sistema de Jornada Única (Decreto 28170 de 21/1/88), isto é, freqüência à escola por um período de 6 horas diárias, e de acordo com a Resolução ${ }^{\circ}$ 62 de 13/3/89, recebendo três refeições, com a meta de suprir 720 Kcal e $22 \mathrm{~g}$ de proteínas (SILVA, 1996).

Fato importante a ser registrado em 1988, foi a inclusão na Constituição, em seu Artigo 208 do capítulo III, da Merenda Escolar como dever do Estado, garantindo no mínimo $15 \%$ das necessidades nutricionais do escolar.

Durante o ano de 1990, a FAE adquiriu 138.116 toneladas de alimentos, básicos e formulados, a um custo de US\$ 402 milhões. O total de alimentos, foi suficiente para o atendimento de 30\% (60 dias) da meta inicial (SILVA, 1996). No ano seguinte, foi adquirido o mesmo volume de alimentos, mas o valor dispensado foi de US\$ 281 milhões; esta diferença foi atribuída à diminuição dos preços dos produtos formulados e do abandono progressivo, pela FAE, da compra desses produtos, tradicionalmente mais caros (PELIANO e BEGHIN, 1994).

Em 1993, a FAE implementou a política de descentralização, firmando 310 convênios, com municípios de todo o país e manteve os convênios com as 27 unidades da federação para atender aos municípios não participantes do processo.

A descentralização da merenda escolar foi concretizada em julho de 1994, por meio da Lei Federal 8.913/94. Essa lei, em seu Artigo $4^{\circ}$, determina que a elaboração dos cardápios dos programas de alimentação escolar, sob a responsabilidade dos estados e municípios, através de nutricionista, seja desenvolvida em acordo com o Conselho de Alimentação Escolar e respeitando os hábitos alimentares de cada localidade, sua vocação agrícola e a preferência por produtos in natura. Essa Lei define ainda, em seu Artigo $2^{\circ}$ a 
composição dos Conselhos de Alimentação Escolar: representantes do órgão de administração da educação pública, dos professores, dos pais e alunos, de trabalhadores e outros da sociedade local (FAE, 1994).

A FAE, por meio da Diretoria de Apoio Alimentar e Nutricional, elaborou um documento de orientação aos municípios, sobre os aspectos que deveriam ser considerados no planejamento e na organização de um programa de alimentação escolar. Nesse documento a FAE expõe, como objetivo do PNAE, a melhoria nos níveis de alimentação e nutrição do estudante com vistas ao melhor rendimento escolar. Esclarece ainda, que a alimentação escolar é entendida como a refeição que a criança recebe, para cobrir seu gasto nutricional, durante o período que permanece na escola, sendo que o PNAE estabeleceu que cada refeição deve atender $15 \%$ das necessidades de energia e proteína para um turno de 4 horas. Cita, como exemplo, um cardápio que contém 320 Kcals e 13,4g de protéica: $50 \mathrm{~g}$ de arroz, $20 \mathrm{~g}$ de cenoura, $50 \mathrm{~g}$ de frango e $5 \mathrm{~g}$ de óleo. O Decreto $\mathrm{n}^{\circ} 23.632$ de 5/7/85 fixa os valores nutricionais mínimos para os escolares do PME de $300 \mathrm{Kcal}$ e $8 \mathrm{~g}$ de proteínas para crianças com três horas de atividades escolares.

Segundo diretrizes da FAE de 1994, a refeição diária do PNAE deveria fornecer no mínimo $15 \%$ das necessidades nutricionais de energia e de proteínas, durante 200 dias letivos (350 kcals e $9 \mathrm{~g}$ de proteínas), para aproximadamente, 30 milhões de alunos, com o objetivo de melhorar os níveis de alimentação e nutrição do estudante, com vistas ao seu melhor rendimento escolar.

No planejamento do cardápio, a FAE recomendava que se considerasse os hábitos e as preferências alimentares locais e incentivasse a formação dos hábitos alimentares sadios, valorizando os espaços educativos. Recomendava ainda, o uso mais freqüente de frutas e verduras. 
Em 1994, a política de descentralização foi estendida a todos os municípios do país que tinham infra-estrutura operacional e administrativa capaz de gerenciar o programa. Nesse ano, a FAE firmou convênio com 2500 municípios.

A FAE foi extinta em 1997 dando lugar à Fundação Nacional de Desenvolvimento da Educação - FNDE** , que continuou normatizando o PNAE.

Em São Paulo, o Decreto $n^{\circ} 40.685$ de 26/2/96, cria o Conselho Estadual de Alimentação Escolar - $\operatorname{CEAE}^{*}$ que tem por finalidade controlar e fiscalizar a aplicação de recursos financeiros federais, repassados ao Governo do Estado e recursos financeiros estaduais, repassados às Prefeituras Municipais, destinados à merenda escolar; tem ainda a finalidade de articular-se com órgãos da administração pública ou privada, no intuito de promover a melhoria do programa de merenda escolar, especialmente quanto à elaboração de cardápios.

No ano de 1996, dos 625 municípios do Estado de São Paulo, 425 estavam descentralizados por convênio. Nesse mesmo ano a FAE baixou a Portaria 291/96, dando autonomia aos municípios para definirem os alimentos que compõem os cardápios e regulamentando as normas para o controle de qualidade. O Departamento de Suprimento Escolar (DSE) ${ }^{*}$ de São Paulo, se organizou com o modelo de gestão dividido em dois sistemas: o descentralizado, onde o DSE repassa recursos financeiros para os municípios (R\$ 0,06/aluno/dia) e estes, compram a merenda e a centralizada, onde o DSE compra a merenda e transporta aos municípios e às escolas. Somente 23 municípios (a Capital e 22 municípios circunvizinhos) pertencem a este último sistema.

\footnotetext{
** FNDE - Fundação Nacional de Desenvolvimento de Educação

* CEAE - Conselho Estadual de Alimentação Escolar

- DSE - Departamento de Suprimento Escolar.
} 
O Departamento de Suprimento Escolar (DSE), nesse mesmo ano, forneceu merenda escolar, de forma centralizada, à aproximadamente 1,5 milhões de alunos de um mil e quinhentas unidades escolares, do Ensino Fundamental da Rede Estadual, localizadas na capital e em vinte e dois municípios do Estado. Os demais 4,8 milhões de alunos, foram atendidos pelo repasse financeiro aos 601 municípios, integrantes do sistema descentralizado de merenda escolar.

Em agosto de 1996, o DSE implantou o Programa de Enriquecimento da Merenda Escolar-PEME, que consiste no repasse de verba às unidades escolares do sistema centralizado (escolarização), para aquisição de alguns alimentos pereciveis, que possam complementar o cardápio básico. Este programa, reforça a política de descentralização, adotada pelo Governo do Estado, permitindo a redução dos custos, a melhoria de qualidade, e a diversificação da merenda. Trimestralmente o DSE publica, no Diário Oficial do Estado, o cardápio a ser seguido pelas escolas estaduais do sistema centralizado de merenda escolar. (SES, 1996).

O DSE define como objetivo do Programa de Alimentação Escolar, por ele gerenciado, a promoção das condições nutricionais dos escolares matriculados na Rede Estadual de Ensino, através de suplementação e educação alimentar. Tanto o objetivo, como as metas de atendimento, coincidem com as do PNAE: A merenda suplementa as exigências nutricionais diárias da criança durante o período de permanência na escola, garantindo os níveis de atenção necessários às atividades pedagógicas. A proposta do DSE é cobrir 15 a $20 \%$ das necessidades nutricionais diárias, principalmente em termos calóricos-protéicos, o que significa oferecer $350 \mathrm{Kcal} \mathrm{e} 9 \mathrm{~g}$ de proteína por refeição.

No periodo de fevereiro a abril de 1997 , foi realizada a avaliação, nas escolas estaduais dos municípios de São Paulo, Cotia, Diadema, Guarulhos, Ribeirão Pires e 
Taubaté, sobre a oferta efetiva de alimentos da merenda escolar centralizada. Considerouse como oferta efetiva de alimentos, a quantidade total preparada para o número de alunos do turno, inscritos no Programa de Merenda Escolar. Encontrou-se que as escolas que contavam com o Programa de Enriquecimento, não seguiam as recomendações, ao adquirirem alimentos para acrescentar ao cardápio padrão; não observavam as quantidades per capita a serem preparadas e, portanto, os porcionamentos definidos pelo DSE; na maioria absoluta das escolas o valor calórico-proteíco da merenda oferecida, não atingia a proposta de $350 \mathrm{Kcal}$ e $9 \mathrm{~g}$ de proteína*.

Ao final deste capítulo, que teve o objetivo de reconstituir a trajetória do Programa de Merenda Escolar, cabem algumas considerações:

a) durante todo o período de existência desse programa, os objetivos explícitos nos documentos oficiais se mantiveram: "melhorar as condições nutricionais dos escolares através da educação e suplementação alimentar" com algumas modificações adicionais em algumas épocas, porém mantendo essa finalidade central.

b) O programa estabeleceu, nos diferentes periodos, as metas de atendimento de $15 \%$ a $30 \%$ das necessidades nutricionais, destacando sempre as energéticas e protéicas.

c) Os alimentos que compuseram a merenda escolar variaram de acordo com os interesses políticos, nacionais e internacionais de cada período.

d) A preocupação com o atendimento das necessidades de vitaminas e minerais, aparecem em poucas oportunidades, ficando subentendido que, ao atender as necessidades protéicas e energéticas, os outros nutrientes também participariam

\footnotetext{
- Dados fornecidos pela Assessoria Técnica de Planejamento e Controle Educacional da SEESP, Merenda Escolar, 1996.
} 
na mesma proporção, o que na maioria absoluta das vezes não corresponde à realidade;

e) A importância do Programa de Merenda Escolar sempre foi atribuída às grandes quantidades de alimentos distribuídos, ao custo e ao número de escolares atendidos. A aceitação e a contribuição à alimentação do escolar nunca foram consideradas nas escassas tentativas de avaliação.

f) Encontram-se registrados, nos documentos oficiais e em alguns estudos, os alimentos que compuseram a merenda escolar em diferentes períodos:

- década de 40 - conforme Dante Costa escreveu, a merenda era composta de um sanduíche, contendo carne, frango, queijo, ovo e verduras, fruta em (suco, ou inteira) e leite; variava ainda com os hábitos regionais. A análise da composição dessa merenda, nas quantidades definidas nos documentos, permite concluir que fornecia $506 \mathrm{Kcal}, 21 \mathrm{~g}$ de proteína, $0,8 \mathrm{mg}$ de ferro e $52 \mathrm{mg}$ de vitamina C (Anexo III).

- década de 50 - a merenda se constituía do leite, "doado" pelo UNICEF e comprado da Commodit Credit Corporation, enriquecido com farinhas de milho, de trigo de aveia, de soja ou mista e complementado com outros alimentos, adquiridos com recursos da Caixa Escolar. Recomendava-se por meio da "Cartilha da Merenda Escolar", (SANTOS \& PAES, 1956) que a merenda não deveria substituir nenhuma refeição da casa; que os alimentos deveriam ser de fácil e rápida digestão e as preparações rápidas. $\mathrm{O}$ cardápio sugerido constituía-se de mingau (leite com alguma dessas farinhas) ou sopa de verduras, legumes, feijão, ou grão de bico, sanduíches, frutas frescas e bebidas a base de leite. 
- década de 60 - Findou a participação do UNICEF e começa a da USAID. Após 1964, surgem as participações do Programa Alimentos para a Paz e do Programa Mundial de Alimentos. O cardápio se compunha de leite, trigo bulgor, trigo laminado, farinha de milho, manteiga e óleo vegetal em quantidades não mencionadas.

Após 1966 - começa o incentivo à fabricação de formulados; a USAID passa a enviar o preparado CSM (corn-soy milk).

Estudo sobre a merenda escolar do município de São Paulo que funcionava de forma diferente do PNAE, pois contava com subsídios relevantes da Prefeitura Municipal, em 1969, apresentou uma composição que fornecia aos escolares, 366 a $390 \mathrm{kcal}, 10 \mathrm{~g}$ de proteína, $0,60 \mathrm{mg}$ de ferro e $1,75 \mathrm{mg}$ de vitamina $\mathrm{C}$, constituída de pão com margarina ou mel e leite com chocolate. Essa merenda era fornecida três vezes por semana, em dias alternados; Nos outros dias eram servidos: sopa de fubá com CSM contendo 170 kcals e 3,6 g de proteínas; leite com canjica com 220 kcals e $9 \mathrm{~g}$ de proteína e em outro dia a merenda servida era sopa liofilizada com macarrão, totalizando $145 \mathrm{Kcals} \mathrm{e} \mathrm{6,5} \mathrm{g} \mathrm{de} \mathrm{proteínas} \mathrm{(ROSENBURG,} \mathrm{1972).}$ (Anexo III).

- década de 70 - a merenda se constituía de alimentos formulados. A sugestão de cardápio semanal se compunha de: leite com farinha de "sojarroz", leite com frutas; sopa de feijão com macarrão; leite com chocolate; sopa de legumes com “sojarroz”, canjica com farinha de amendoim (Anexo III). No final da década de 70 , especialistas da área de nutrição sugeriam cardápio com alimentos não formulados, como exemplo: leite com 
chocolate, açucar, pão com patê de fígado e banana. (360 Kcal, 5,4 g de proteína de bom valor biológico) (ANEXO III).

- década de 80 - Alimentos formulados e in natura

Inicia-se o processo de municipalização da merenda escolar em São Paulo. Mesmo assim, 70\% dos cardápios, em 1988, eram compostos por produtos formulados - bebidas lácteas, biscoitos, macarrão, risotos, polentas, etc.

- década de 90 - Concretiza-se a descentralização do programa federal e estadual com os processos de municipalização e escolarização. A proporção de formulados passa a ser cada vez menor na composição dos cardápios, especialmente no Estado de São Paulo. 


\subsection{ESTUDO DE CASO: ANEMIA FERROPRIVA E PROGRAMA DE MERENDA ESCOLAR}

\section{Resultados do estudo de prevalência de anemia em escolares do município de Santos}

\subsubsection{População de estudo}

O universo de estudo, conforme exposto na Tabela 1 da Metodologia, foi constituído por escolares matriculados nas 27 escolas públicas do Município de Santos, no ano de 1996 , nas $1^{\text {as }}, 5^{\text {as }}$ e $8^{\text {as }}$ séries.

O número total efetivo de alunos matriculados nessas escolas, por ocasião da pesquisa, considerando os dados de transferência e evasão encontrados na amostra estudada, foi de 5675 e estão distribuídos, por região geográfica e por série escolar, na Tabela 3. Essa tabela também apresenta a distribuição da amostra, constituída dos alunos matriculados nas $1^{\text {as }}, 5^{\text {as }}$ e $8^{\text {as }}$ séries das 27 classes sorteadas. Os números apresentados nessa amostra se referem aos dos escolares que foram examinados, isto é foram excluídos os que faltaram no dia do exame $(9,8 \%)$, os que se recusaram $(1,0 \%)$ e os que não tiveram a autorização dos pais $(7,6 \%)$.

Tabela 3 - População total dos alunos matriculados por ocasião da pesquisa e amostra estudada, distribuídos por série escolar e região geográfica das escolas públicas. Municípios de Santos/SP, 1996.

\begin{tabular}{|c|c|c|c|c|c|c|c|c|}
\hline \multirow{2}{*}{$\begin{array}{l}\text { Regiāo } \\
\text { Geográfica }\end{array}$} & \multicolumn{2}{|c|}{ I $^{\mathrm{a}}$ SÉRIE } & \multicolumn{2}{|c|}{$5^{2}$ SÉRIE } & \multicolumn{2}{|c|}{$8^{\mathrm{a}}$ SERIE } & \multicolumn{2}{|c|}{ TOTAL } \\
\hline & $\begin{array}{c}\text { Alunos } \\
\text { na popul } \\
\left(n^{\circ}\right)\end{array}$ & $\begin{array}{c}\text { Alunos } \\
\text { na Amostra } \\
\left(\mathrm{n}^{\circ}\right)\end{array}$ & $\begin{array}{l}\text { Alunos. } \\
\text { na popul. } \\
\left(n^{\circ}\right)\end{array}$ & $\begin{array}{c}\text { Alunos } \\
\text { na Amostra } \\
\left(n^{\circ}\right)\end{array}$ & $\begin{array}{c}\text { Alunos. } \\
\text { na popul } \\
\left(n^{\circ}\right)\end{array}$ & $\begin{array}{c}\text { Alunos } \\
\text { na Amostra } \\
\left(n^{\circ}\right)\end{array}$ & $\begin{array}{c}\text { Alunos } \\
\text { na popul. } \\
\left(n^{\circ}\right)\end{array}$ & $\begin{array}{c}\text { Alunos } \\
\text { na Amostra } \\
\left(\mathrm{n}^{\circ}\right)\end{array}$ \\
\hline ORLA & 1259 & 184 & 951 & 111 & 685 & 51 & 2895 & 346 \\
\hline CENTRAL & 718 & 51 & 438 & 39 & 192 & 27 & 1348 & 117 \\
\hline NOROESTE & 892 & 127 & 250 & 29 & 120 & 16 & 1262 & 172 \\
\hline MORRO & 107 & 34 & 63 & 28 & - & - & 170 & 62 \\
\hline TOTAL & 2976 & 396 & 1702 & 207 & 997 & 94 & 5675 & 697 \\
\hline
\end{tabular}


A amostra foi, portanto, constituída de 697 escolares, sendo 331 (47,5\%) do sexo feminino e $366(52,5 \%)$ do sexo masculino. A distribuição por série escolar segundo o sexo, apresentou proporção semelhante à população total, com ligeira predominância dos meninos. A tabela 4 apresenta os escolares da amostra distribuídos segundo a idade, série escolar e sexo.

Tabela 4 - Distribuição numérica e percentual dos escolares da amostra segundo idade, série escolar e sexo. Município de Santos/SP., 1996.

\begin{tabular}{|c|c|c|c|c|c|c|c|c|}
\hline \multirow{2}{*}{$\begin{array}{l}\text { Idade } \\
\text { (anos) }\end{array}$} & \multicolumn{2}{|c|}{$1^{2}$ SÉRIE } & \multicolumn{2}{|c|}{$5^{a}$ SÉRIE } & \multicolumn{2}{|c|}{$8^{\mathrm{a}}$ SÉRIE } & \multicolumn{2}{|c|}{ TOTAL } \\
\hline & $\begin{array}{l}\mathrm{M} \\
\%\end{array}$ & $\begin{array}{l}F \\
\%\end{array}$ & $\begin{array}{l}\text { M } \\
\%\end{array}$ & $\begin{array}{l}\mathrm{F} \\
\%\end{array}$ & $\begin{array}{l}\mathrm{M} \\
\%\end{array}$ & $\begin{array}{l}\mathrm{F} \\
\% \\
\end{array}$ & $\begin{array}{l}\mathrm{M} \\
\%\end{array}$ & $\begin{array}{l}\mathrm{F} \\
\% \\
\end{array}$ \\
\hline$<8$ & $\begin{array}{c}171 \\
(81,8)\end{array}$ & $\begin{array}{c}147 \\
(80,3)\end{array}$ & - & - & - & - & $\begin{array}{c}171 \\
(47,1)\end{array}$ & $\begin{array}{c}147 \\
(44,7)\end{array}$ \\
\hline $8 \vdash 99$ & $\begin{array}{c}26 \\
(12,4)\end{array}$ & $\begin{array}{c}27 \\
(14,8)\end{array}$ & - & - & - & - & $\begin{array}{c}26 \\
(7,2)\end{array}$ & $\begin{array}{c}27 \\
(8,2)\end{array}$ \\
\hline 9 ト- -10 & $\begin{array}{c}6 \\
(2,9)\end{array}$ & $\begin{array}{c}5 \\
(2,7)\end{array}$ & - & - & - & - & $\begin{array}{c}\mathbf{6} \\
(1,7)\end{array}$ & $\begin{array}{c}5 \\
(1,5)\end{array}$ \\
\hline $10 \vdash--11$ & $\begin{array}{c}2 \\
(1,0)\end{array}$ & $\begin{array}{c}2 \\
(1,1)\end{array}$ & $\begin{array}{c}7 \\
(2,9)\end{array}$ & $\begin{array}{c}12 \\
(11,7)\end{array}$ & - & - & $\stackrel{9}{(2,5)}$ & $\begin{array}{c}14 \\
(4,3)\end{array}$ \\
\hline $11+--12$ & $\begin{array}{c}2 \\
(1,0)\end{array}$ & $\begin{array}{c}1 \\
(0,5)\end{array}$ & $\begin{array}{c}47 \\
(45,2)\end{array}$ & $\begin{array}{c}59 \\
(57,3)\end{array}$ & - & - & $\begin{array}{c}49 \\
(13,5)\end{array}$ & $\begin{array}{r}60 \\
(18,2)\end{array}$ \\
\hline $12 \vdash-13$ & $\begin{array}{c}1 \\
(0,5)\end{array}$ & $\begin{array}{c}1 \\
(0,5)\end{array}$ & $\begin{array}{c}27 \\
(26,0)\end{array}$ & $\begin{array}{c}16 \\
(15,5)\end{array}$ & - & - & $\begin{array}{r}28 \\
(7,7)\end{array}$ & $\begin{array}{c}17 \\
(5,2)\end{array}$ \\
\hline $13 \vdash--14$ & $\begin{array}{c}1 \\
(0,5)\end{array}$ & : & $\begin{array}{c}16 \\
(15,4)\end{array}$ & $\begin{array}{c}12 \\
(11,7)\end{array}$ & $\begin{array}{c}9 \\
(18,0)\end{array}$ & $\begin{array}{c}6 \\
(14,0)\end{array}$ & $\begin{array}{c}26 \\
(7,2)\end{array}$ & $\begin{array}{c}18 \\
(5,5)\end{array}$ \\
\hline$>=14$ & & - & $\begin{array}{c}7 \\
(6,7) \\
\end{array}$ & $\begin{array}{c}4 \\
(3,9) \\
\end{array}$ & $\begin{array}{c}41 \\
(82,0) \\
\end{array}$ & $\begin{array}{c}37 \\
(86,0) \\
\end{array}$ & $\begin{array}{c}48 \\
(13,2) \\
\end{array}$ & $\begin{array}{c}41 \\
(12,5) \\
\end{array}$ \\
\hline TOTAL & $\begin{array}{c}209 \\
(100,0) \\
\end{array}$ & $\begin{array}{c}183 \\
(100,0) \\
\end{array}$ & $\begin{array}{c}104 \\
(100,0) \\
\end{array}$ & $\begin{array}{c}103 \\
(100,0) \\
\end{array}$ & $\begin{array}{c}50 \\
(100,0) \\
\end{array}$ & $\begin{array}{c}43 \\
(100,0) \\
\end{array}$ & $\begin{array}{c}363 \\
(100,0) \\
\end{array}$ & $\begin{array}{c}329 \\
(100,0)\end{array}$ \\
\hline
\end{tabular}

\subsubsection{Escolaridade dos pais}

As distribuições da escolaridade do pai e da mãe dos escolares estudados estão representadas nas figuras 2 a. e 2.b; respectivamente. Observa-se que o perfil de 
escolaridade dos pais dos alunos da $8^{\mathrm{a}}$ série tende a ser melhor do que o dos pais de $1^{\mathrm{a}}$ série indicando condição social mais favoráveils das crianças que alcançaram a $8^{\mathrm{a}}$ série.

Comparando a variável de escolaridade dos pais de ingressantes nas escolas públicas de outras localidades, como por exemplo, de Maringá, no Paraná (UCHIMURA, 1994) e em Osasco, São Paulo (STEFANINI e col., 1995), esta situação encontrada em Santos, pode ser considerada mais favorável: $18,9 \%$ dos pais de escolares de $1^{\text {a }}$ série das escolas públicas do município de Santos e 44,6\% do município de Maringá, cursaram menos de quatro anos de escola; em Osasco, $21 \%$ dos pais dos escolares de $1^{\text {a }}$ série tinham menos de quatro anos de estudo. Em análise comparativa do perfil de condições de vida e saúde dos grandes municípios de São Paulo, KAYANO e col. (1995) registraram para a população de Santos 5,4\% de analfabetos em maiores de 15 anos, sendo o menor "indice de analfabetismo apresentado entre os quarenta e nove municípios estudados.

\subsubsection{Região Geográfica}

Observa-se na Tabela 5 os níveis de escolaridade dos pais dos alunos segundo as escolas amostradas e as regiões geográficas.

Os perfis de escolaridade dos pais das crianças que estudam nas escolas das Regiões do "Morro" e "Noroeste" parecem piores do que o das regiões da Orla e Central. Encontrou-se associação estatisticamente significante entre pertencer às Regiões Geográficas do "Morro" e "Noroeste" e ser analfabeto. 
Figura 2a. Escolaridade do Pai, segundo as séries dos escolares. Santos/SP 1996

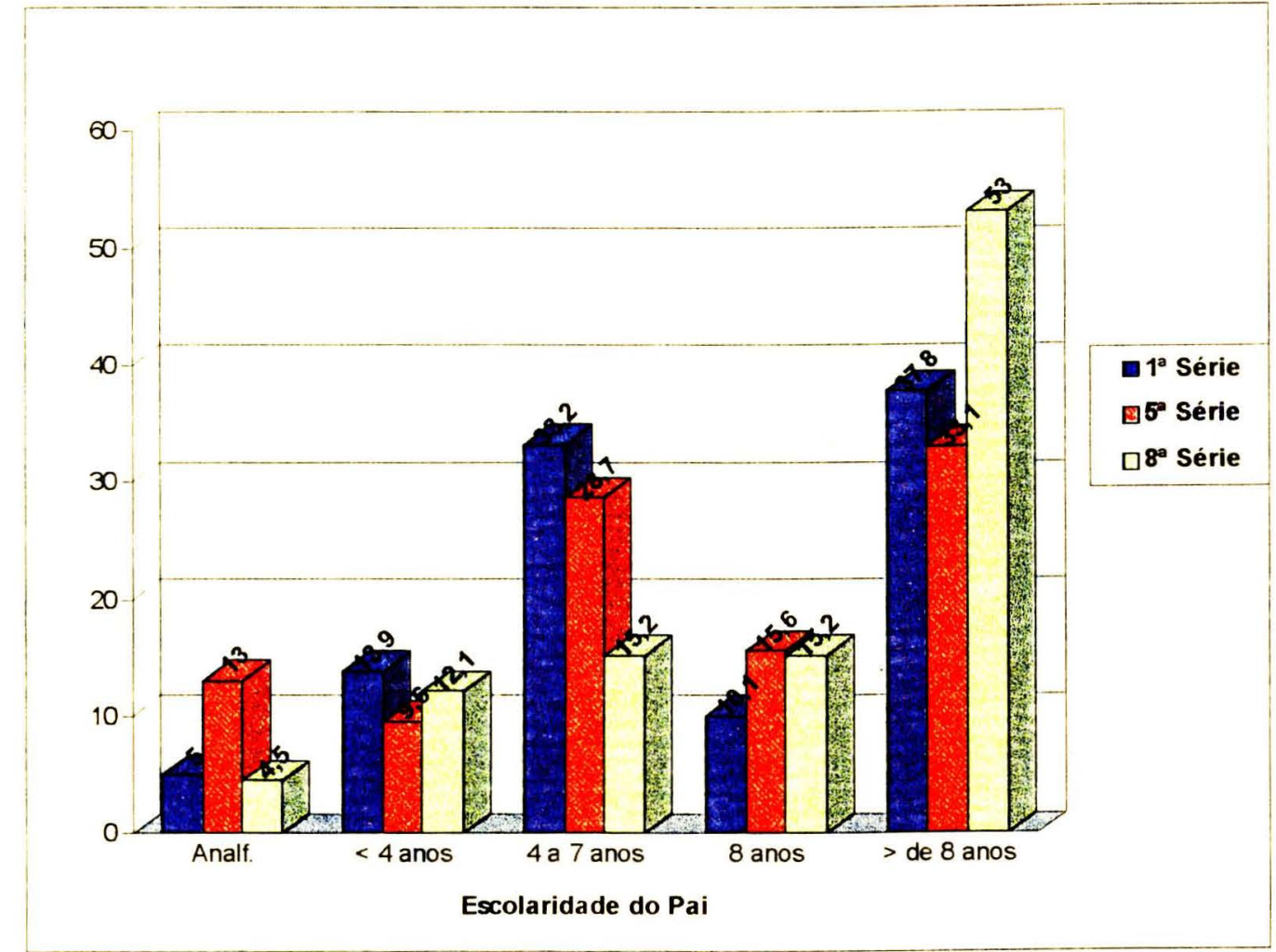

Figura 2b. Escolaridade da Mãe, segundo as séries dos escolares. Santos/SP 1996

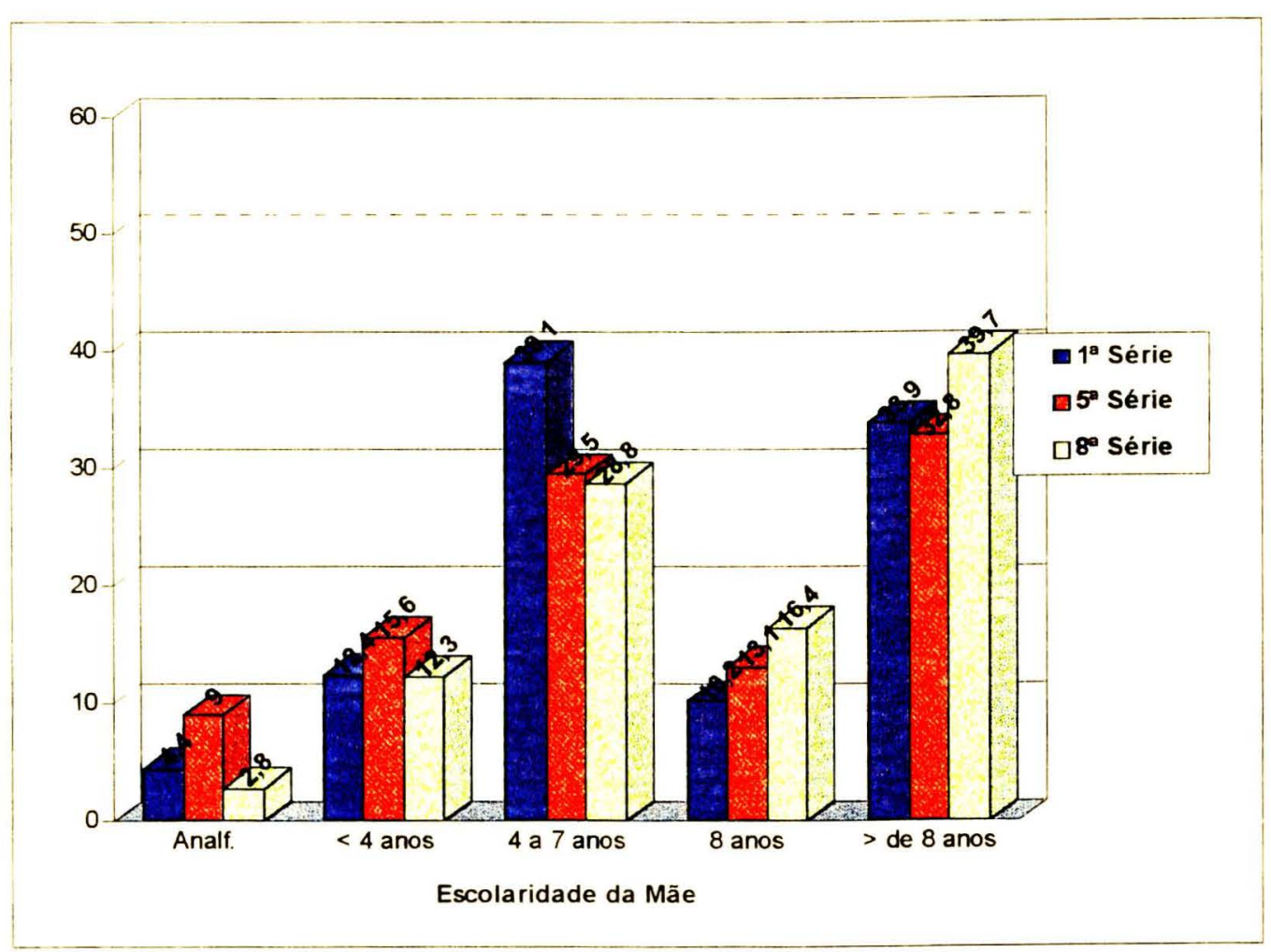


Tabela 5 - Distribuição dos alunos segundo escolaridade do pai e região geográfica das escolas. Município de Santos/SP, 1996.

\begin{tabular}{|c|c|c|c|c|c|c|c|c|c|c|}
\hline \multirow{3}{*}{$\begin{array}{l}\text { ESCOLARI- } \\
\text { DADE DO PAI }\end{array}$} & \multicolumn{8}{|c|}{ REGIAOO GEOGRAFICA } & \multirow{2}{*}{\multicolumn{2}{|c|}{ TOTAL }} \\
\hline & \multicolumn{2}{|c|}{ ORLA } & \multicolumn{2}{|c|}{ CENTRAL } & \multicolumn{2}{|c|}{ NOROESTE } & \multicolumn{2}{|c|}{ MORRO } & & \\
\hline & $n$ & $\%$ & $\mathrm{n}$ & $\%$ & $\mathrm{n}$ & $\%$ & & $\%$ & $\mathrm{n}$ & $\%$ \\
\hline Analfabeto & & $(3,4)$ & & $(6,2)$ & & $(8,9)$ & & $(17,1)$ & 33 & $6,1)$ \\
\hline$<4$ anos & 11 & $(3,8)$ & 22 & $(27,2)$ & & $(6,5)$ & 3 & $(7,3)$ & 44 & $8,1)$ \\
\hline 4 a 7 anos & & $(21,2)$ & 28 & $(34,6)$ & & $(43,9)$ & 18 & $(43,9)$ & 162 & $29,9)$ \\
\hline 8 anos & 42 & $(14,4)$ & 13 & $(16,6)$ & & $(14,6)$ & 8 & $(19,5)$ & 81 & $15,0)$ \\
\hline+8 anos & 167 & $(57,2)$ & 13 & $(16,0)$ & & $(26,0)$ & 5 & $(12,2)$ & 217 & $40,9)$ \\
\hline TOTAL & 292 & $(100,0)$ & 81 & $(100,0)$ & 123 & $(100,0)$ & & $(100,0)$ & 537 & $\overline{100,0)}$ \\
\hline
\end{tabular}

\subsubsection{Estado Nutricional}

A avaliação do estado nutricional foi incluída neste estudo para contribuir com a análise das necessidades nutricionais da população estudada. A presença prolongada da desnutrição energético-proteíca nas fases de crescimento, anteriores à vida escolar, é denunciada pela inadequação na relação altura para a idade (A/I). Já a utilização do indicador peso para a idade $(\mathrm{P} / \mathrm{I})$, pode indicar a presença da desnutrição no momento do diagnóstico ou em período anterior (WHO, 1986). Conhecer o comportamento desses indicadores na população torna-se fundamental quando se pretende avaliar as políticas sociais que estão sendo conduzidas e propor alterações.

Utilizou-se esses dois indicadores (A/I e P/I) que foram expressos em escore $\mathrm{Z}$. A distribuição dos valores de escore $\mathrm{Z}$ dos índices, peso para idade (P/I) e altura para idade (A/I) para a população estudada, apresentaram curvas bem aproximadas às de referência (NCHS). A prevalência de valores abaixo de -2 escore $Z$ para $A / I$, foi de $3,29 \%$ e de $P / I$ foi de $1,86 \%$, praticamente o esperado para uma população de crianças que não apresentaram 
episódios frequentes e prolongados de desnutrição energético-protéico nas fases mais criticas do crescimento.

A população de estudo se compôs de escolares cujas idades variaram de 7 a 16 anos, incluindo, portanto, os periodos da pré-adolescência e da adolescência; nessas fases a escolha de indicador para diagnóstico nutricional, que utiliza apenas medidas antropométricas, é muito polêmica. Esses indicadores definem bem a situação nutricional das crianças da $1^{a}$ série, pois estas estão em idades anteriores à pré-adolescência. As distribuições das crianças de 7 anos, segundo escore $Z$ de altura para idade, da população de referência (NCHS) e deste estudo, podem ser observadas na Figura 2.

Figura 2: Distribuição das crianças da $1^{\mathrm{a}}$ série segundo indicador altura para idade expresso em z-score. Município de Santos/SP, 1996.

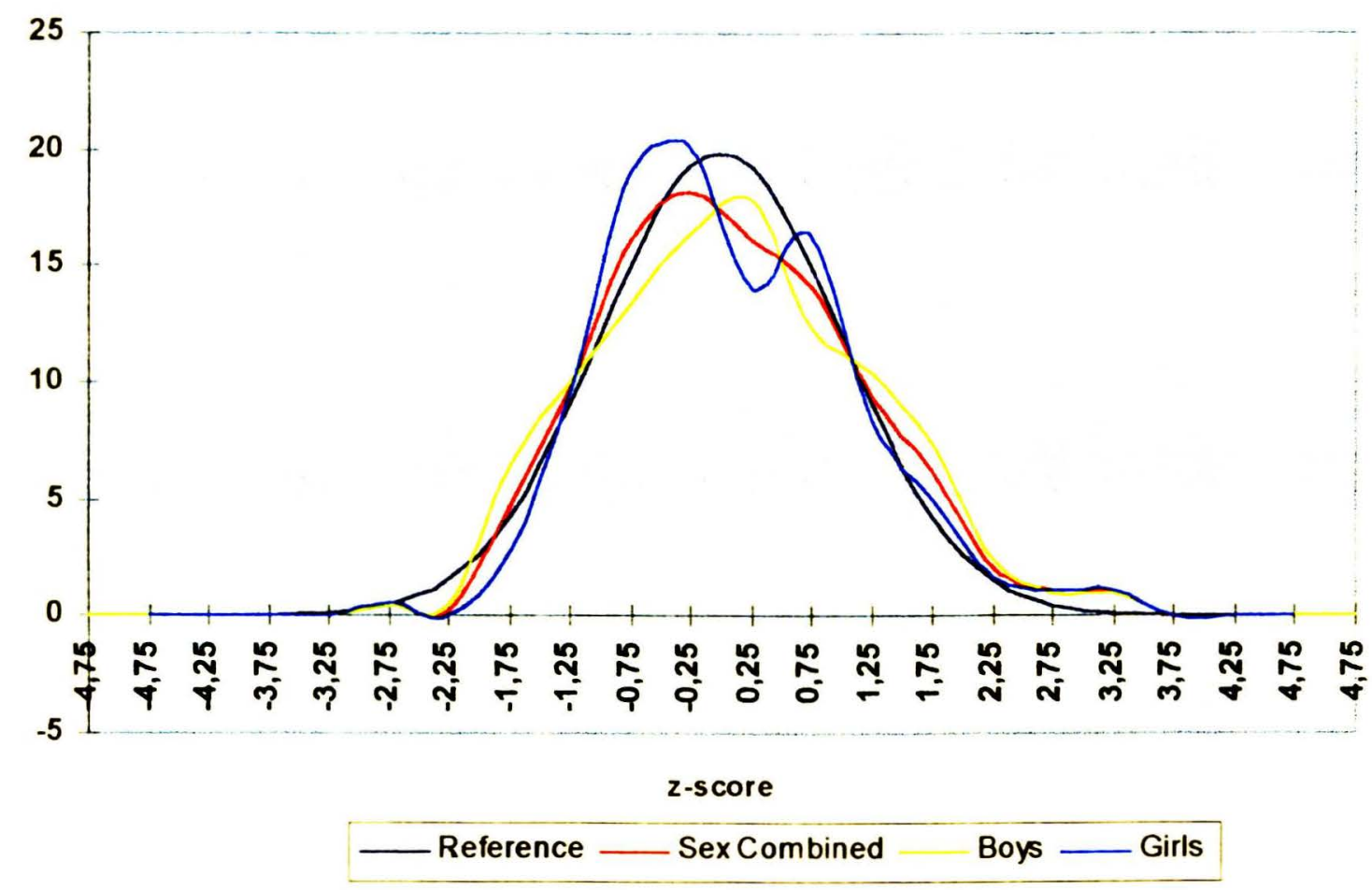




\subsubsection{Prevalência de anemia}

O parâmetro que define a presença de anemia, de acordo com a OMS, é a concentração de hemoglobina. Essa medida, é o teste laboratorial indispensável na triagem da patologia por deficiência de ferro, pois reflete diretamente a quantidade desse mineral no organismo. O estágio avançado da deficiência de ferro está associado à diminuição significativa de concentração da hemoglobina no sangue; esse indicador permite de maneira relativamente simples, devido à praticidade de coleta e de obtenção do resultado, a realização de rastreamento ("screening") e de avaliação de resposta a programas de intervenção com ferro.

No presente estudo, a concentração média dos valores de hemoglobina ( $\mathrm{Hb})$ encontrada entre os escolares foi de $12,81 \mathrm{~g} / \mathrm{dl}$ e a distribuição das médias conforme o sexo e as séries escolares, pode ser observada na tabela 6.

Tabela 6 - Concentração média de Hb (g/dl) e desvio padrão, segundo sexo e série escolar. Município de Santos, 1996.

\begin{tabular}{|c|c|c|c|c|c|c|c|c|c|c|c|c|}
\hline \multirow[b]{2}{*}{ Sexo } & \multicolumn{3}{|c|}{$\begin{array}{l}\text { I" Série } \\
\text { média }\end{array}$} & \multicolumn{3}{|c|}{$\begin{array}{l}5^{2} \text { Série } \\
\text { média }\end{array}$} & \multicolumn{3}{|c|}{$\begin{array}{l}8^{\mathrm{a}} \text { Série } \\
\text { média }\end{array}$} & \multicolumn{3}{|c|}{$\begin{array}{l}\text { Total } \\
\text { média }\end{array}$} \\
\hline & $\mathbf{n}$ & $\mathrm{Hb}$ & Dp & $\mathrm{n}$ & $\mathrm{Hb}$ & Dp & $\mathrm{n}$ & $\mathrm{Hb}$ & Dp & $n$ & $\mathrm{Hb}$ & Dp \\
\hline Masculino & 212 & 12,51 & 1,07 & 104 & 13,25 & 1,03 & 50 & 14,45 & 1,09 & 366 & 12,98 & 1,25 \\
\hline Feminino & 184 & 12,39 & 1,07 & 103 & 12,84 & 1,31 & 44 & 13,06 & 1,36 & 331 & 12,62 & 1,21 \\
\hline Total & 396 & 12,45 & 1,07 & 207 & 13,05 & 1,19 & 94 & 13,80 & 1,40 & 697 & 12,81 & 1,25 \\
\hline
\end{tabular}

Foram 157 escolares da amostra que apresentaram valores de hemoglobina inferiores ao limite de $12 \mathrm{~g} / \mathrm{dl}$, sendo $122 \mathrm{da} 1^{\mathrm{a}}$ série, $28 \mathrm{da} 5^{\mathrm{a}}$ e $7 \mathrm{da} 8^{\mathrm{a}}$ série. 
Para o cálculo da prevalência de anemia, por série e por região utilizou-se a expressão:

$$
\begin{aligned}
& \mathrm{P}=\text { prevalência } \\
& \hat{\mathrm{p}}_{\mathrm{ij}}=\frac{\mathrm{r}_{\mathrm{ij}}}{\overline{\mathrm{N}}_{\mathrm{ij}} \cdot \mathrm{l}_{\mathrm{ij}}} \quad \text { onde } \Rightarrow \quad \mathrm{i}=\text { região geográfica } \\
& \mathrm{j} \text { = série escolar } \\
& \mathrm{r}=\text { número de escolares, na amostra, com anemia } \\
& \text { ferropriva } \\
& \mathrm{N}=\text { número médio de alunos por classe na } \\
& \text { população } \\
& 1=\text { número de classes na amostra }
\end{aligned}
$$

Para encontrar o número médio de alunos nả população por região geográfica (Nij) utilizou-se a expressão:

\begin{tabular}{|c|c|c|c|c|c|c|c|c|}
\hline \multirow{2}{*}{$\begin{array}{l}\text { REGIÃO } \\
\text { GEOGRÁ- } \\
\text { FICA }\end{array}$} & \multicolumn{2}{|c|}{$1^{\mathrm{a}}$ série } & \multicolumn{2}{|c|}{$5^{\mathrm{a}}$ série } & \multicolumn{2}{|c|}{$8^{\mathrm{a}}$ série } & \multirow{2}{*}{$\begin{array}{l}\text { TOTAL } \\
\text { Prevalência } \\
\text { Estimada(\%) }\end{array}$} & \multirow[b]{2}{*}{$\begin{array}{l}\text { Erro } \\
\text { padrão }\end{array}$} \\
\hline & $\begin{array}{l}\text { Prevalência } \\
\text { Estimada(\%) }\end{array}$ & $\begin{array}{l}\text { Erro } \\
\text { padrão }\end{array}$ & $\begin{array}{l}\text { Prevalência } \\
\text { Estimada(\%) }\end{array}$ & $\begin{array}{l}\text { Erro } \\
\text { padrão }\end{array}$ & $\begin{array}{l}\text { Prevalência } \\
\text { Estimada(\%) }\end{array}$ & $\begin{array}{l}\text { Erro } \\
\text { padrão }\end{array}$ & & \\
\hline ORLA & 18,57 & 0,0246 & 11,36 & 0,0257 & 6,13 & 0,0285 & 13,36 & 0,0235 \\
\hline CENTRAL & 19,23 & 0,0470 & 5,47 & 0,0290 & 6,25 & 0,0397 & 11,59 & 0,0386 \\
\hline NOROESTE & 42,42 & 0,0399 & 19,23 & 0,0671 & 4,17 & 0,0373 & 28,54 & 0,0424 \\
\hline MORRO & 42,02 & 0,0684 & 12,70 & 0,0427 & - & - & 27,94 & - \\
\hline $\begin{array}{c}\text { MÉDIA } \\
\text { DAS RG }\end{array}$ & 27,81 & 0,0293 & 11,31 & 0,0355 & 5,61 & 0,0328 & 20,89 & 0,0187 \\
\hline
\end{tabular}

$$
\begin{aligned}
& N_{i j}=\frac{N_{i j}}{L_{i j}} \quad \text { onde } \Rightarrow \quad N i j=\text { número total efetivo de escolares } \\
& \text { matriculados por ocasião da pesquisa } \\
& \text { Lij = número de classes na população. }
\end{aligned}
$$

Os valores das prevalências de anemia ferropriva estimada para a população, segundo as regiões geográficas e séries escolares encontram-se, expressos em porcentagem, na tabela 7 e podem ser visualizados na Figura 3.

Tabela 7.- Prevalências estimadas (expressas em \%) e os erros-padrão estimados para a população, distribuídos por região geográfica e séries escolares, Município de Santos /SP, 1996. 
Figura 3 - Prevalências estimadas de anemia ferropriva segundo área geográfica e série escolar. Municipio de Santos/SP, 1996

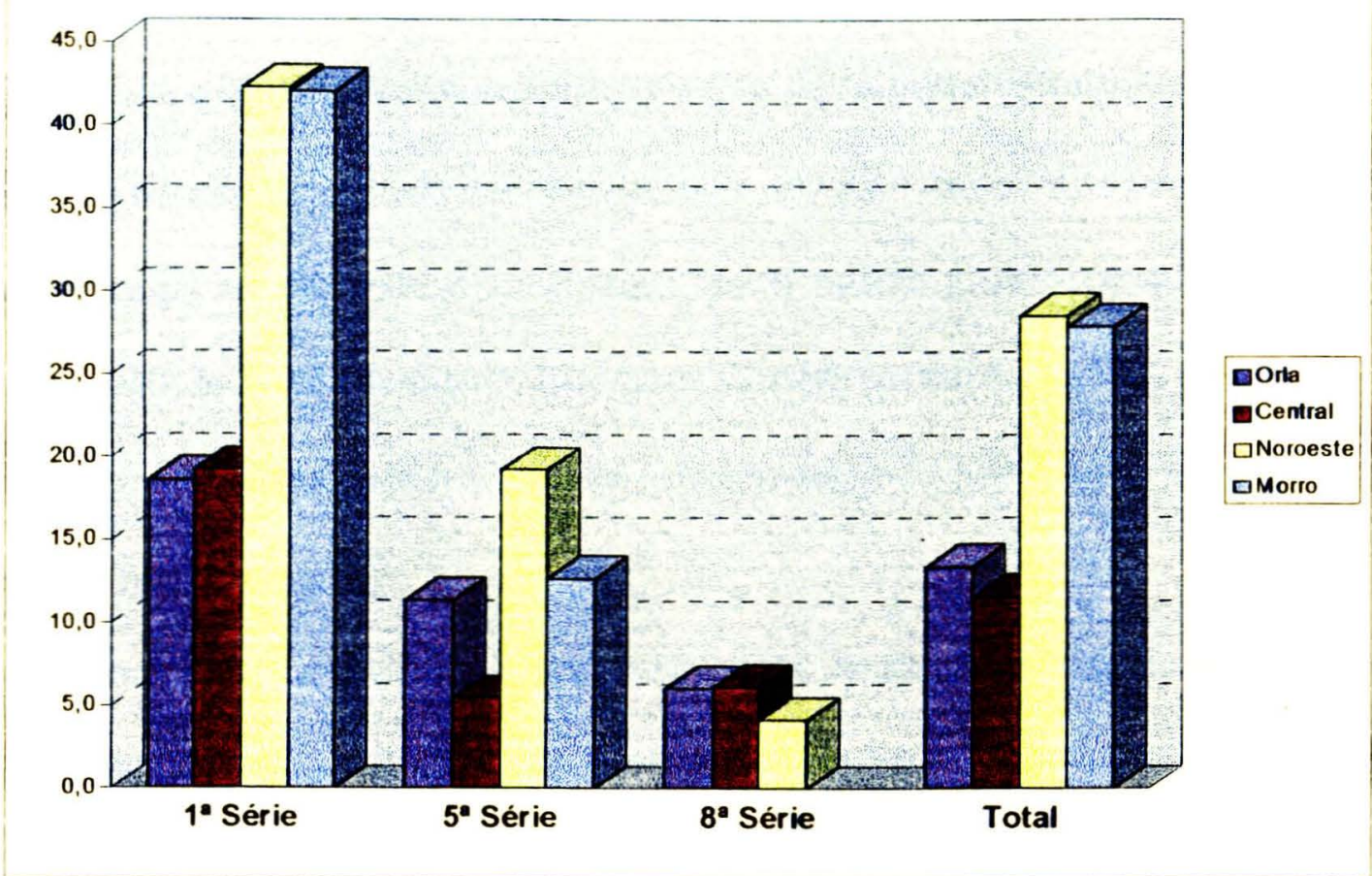

As prevalências estimadas de anemia para escolares das $1^{\text {as }}, 5^{\text {as }}$ e $8^{\text {as }}$ séries do primeiro grau, conforme estão apresentadas na tabela 7 , foram respectivamente, $27,81 \%$, $11,31 \%$ e $5,61 \%$.

Estes resultados confirmaram a hipótese inicial deste estudo, quanto a presença importante da anemia ferropriva em escolares da rede pública de ensino. Ela aparece de forma marcante nas crianças ingressantes ( $1^{2}$ série). Mesmo, as prevalências estimadas para as $5^{*}$ e $8^{\star s}$ séries não são despreziveis, principalmente se forem consideradas pelo menos duas situações: a primeira relacionada a taxa de evasão, já comentada anteriormente, que define uma população bem reduzida nesses estratos quando comparados ao de ingressantes; a segunda situação, diretamente relacionada à anterior, se refere às melhores condições de vida que, provavelmente, têm os escolares que conseguem continuar os estudos até finalizarem o primeiro grau. Por isto, é válido pensar que as crianças que abandonaram a 
escola estão em piores condições de vida e com maiores chances de apresentar problemas nutricionais.

Procurou-se verificar a existência de associação entre a presença de anemia e a escolaridade dos pais das crianças anemicas. Do total de escolares anêmicos, $19,4 \%$ tinham pais que não haviam completado o primário (- de 4 anos de escola), $31,5 \%$ dos pais desses escolares haviam estudado de 4 a 7 anos, 14,2\% tinham ginásio completo e 34,9\% estudaram mais de 8 anos de estudo. Este resultados confirmam a presença importante da anemia nos diferentes estratos sociais, determinada frequentemente por práticas alimentares equivocadas.

Com relação a região geográfica da escola, também sugerida como marcador social, quando examinados os dados de prevalência de anemia estimados, encontra-se para a região Noroeste $28,54 \%$ para a região do Morro $27,94,11,59 \%$ para a Central e $13,36 \%$ para a orla. Estes resultados confirmam que a anemia ferropriva ocorre predominantemente nas regiões sócio-econômicas mais desfavoráveis.

\subsubsection{Discussão}

Devido as altas prevalências de anemia ferropriva que vêm sendo apontadas, alguns estudiosos têm questionado os limites de referência dos níveis de hemoglobina, utilizados pela OMS, para indicar o problema da anemia, principalmente na faixa etária de 6 a 14 anos, quando a criança atravessa períodos diferentes de crescimento. Conforme já apresentado por SZARFARC (1989) e LERNER (1994), o padrão proposto pela OMS apresenta a vantagem indiscutivel do reconhecimento internacional, permitindo a comparabilidade de estudos originários de diferentes países. No entanto, valores fixos de concentração de hemoglobina para a definição do limite crítico, abaixo dos quais o 
indivíduo é considerado anêmico, podem não ser sensíveis às modificações que acompanham o seu desenvolvimento fisiológico; a sensibilidade e especificidade obtidos com a utilização desses valores é muito variável.

Uma forma de analisar os valores encontrados, se refere à utilização de curvas de referência como as elaboradas por DALLMAN \& SIIMES (1979) e utilizadas pelo International Nutritional Anemia Consultative Group (INACG). Esses Autores traçaram curvas de referência com base em levantamento da concentração de hemoglobina de uma população sadia, e propuseram a utilização do percentil $3\left(\mathrm{P}_{3}\right)$ como limite mínimo aceitável.

Lembrando que a anemia é o estágio mais severo da deficiência de ferro no organismo e que sua presença denuncia que as reservas desse mineral já esgotaram, DALLMAN e SIIMES propuseram a utilização do percentil $10\left(\mathrm{P}_{10}\right)$ como limite para indicar provável deficiência de ferro. Valores da concentração de hemoglobina e do volume corpuscular médio (VCM) abaixo desse percentil, indicam risco de deficiência de ferro. Observa-se na tabela 8 as prevalências de anemia por sexo, encontradas neste estudo, segundo os padrões da OMS $(<12 \mathrm{~g} / \mathrm{dl})$ e segundo os valores abaixo do percentil $\left(<\mathrm{P}_{10}\right)$ proposto por esses autores. Não foi encontrada diferença significativa de prevalência de anemia entre os dois padrões.

Tabela 8 - Prevalência de anemia segundo os padrões da OMS e de D \& S, nos escolares da amostra. Município de Santos/SP, 1996.

\begin{tabular}{l|ccc}
\hline \multicolumn{1}{c|}{ Sexo } & Tamanho da amostra & $\begin{array}{c}\text { OMS } \\
\%\end{array}$ & $\begin{array}{c}\text { D \& S } \\
\%\end{array}$ \\
& & 18,8 & 22,13 \\
Masculino & 366 & 26,59 & 25,98 \\
Feminino & 331 & 22,52 & 23,96 \\
\hline Total & 697 & & \\
\hline
\end{tabular}


As figuras $4 a$ e $4 b$ apresentam a distribuição de concentração de hemoglobina da população estudada, e as curvas de referência de DALLMAN \& SIIMES (D \& $S)\left(\mathrm{P}_{3}, \mathrm{P}_{10} \mathrm{e}\right.$ $\left.\mathbf{P}_{50}\right)$.

Fig 4a - Distribuiçăo dos valores de hemoglobina, sexo masculino por idade da populaçăo estudada e curvas de Dallman e Siimes, Santos/SP, 1996.

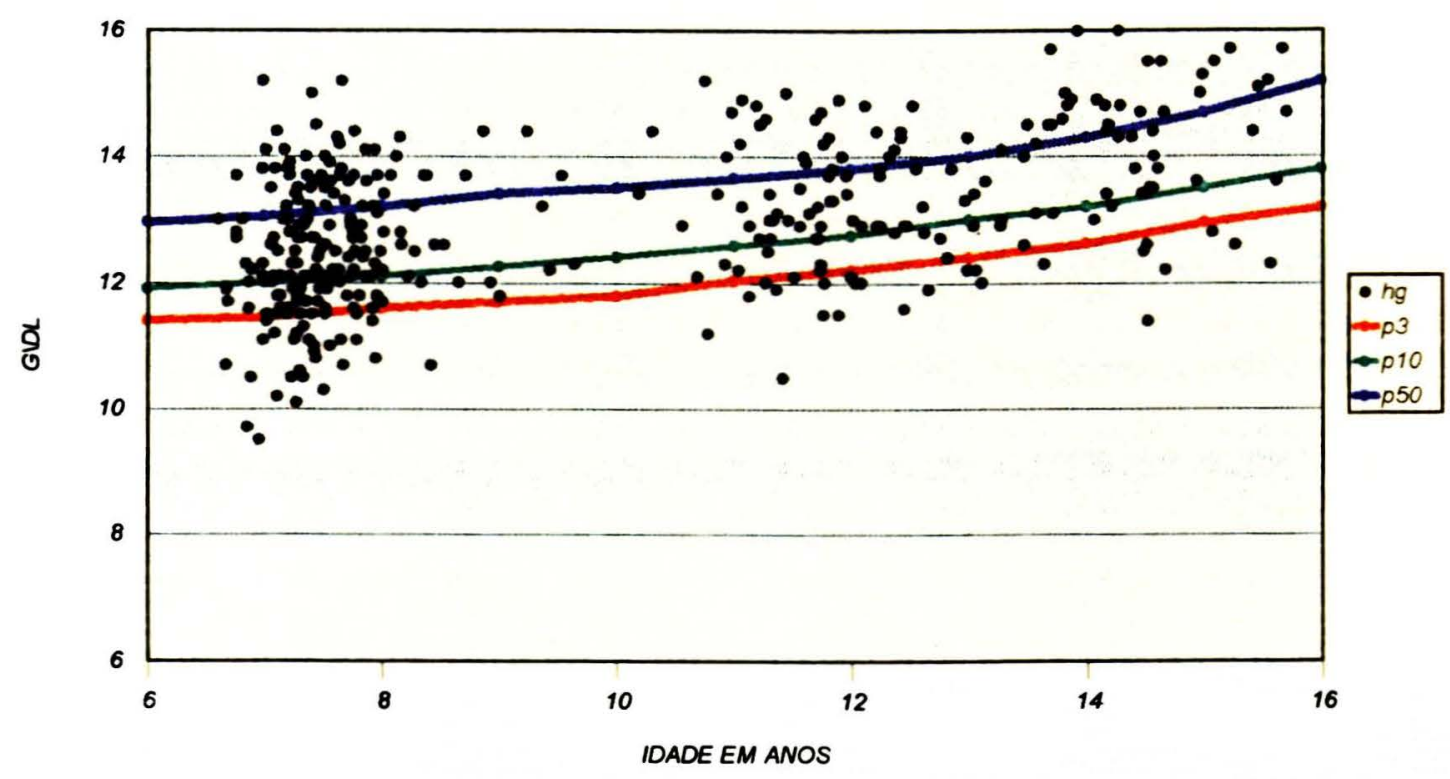

Fig $4 b$ - Distribuiçăo dos valores de hemoglobina, sexo feminino por idade da populaçăo estudada e curvas de Dallman e Siimes, Santos/SP, 1996.

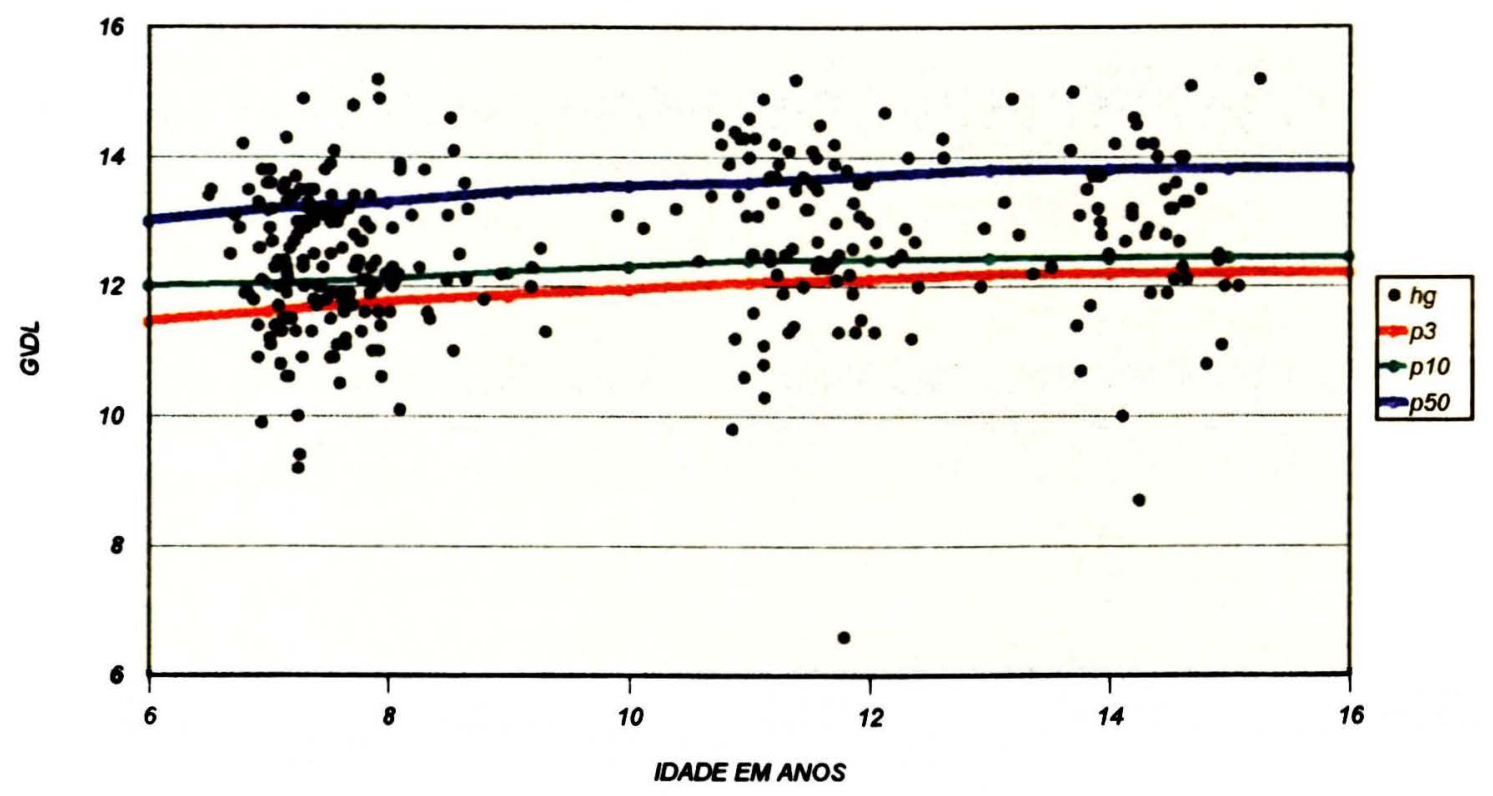


Reafirmando a anemia como reflexo de uma deficiência severa de ferro, VITERI e col. (1972) verificaram que o limite de um desvio-padrão abaixo da média de concentração de hemoglobina de um grupo de referência, indica um risco de $20 \%$ de deficiência de ferro e o limite de um e meio desvios-padrão, aumentaria esse risco para $75 \%$.

Utilizando esses valores de cortes propostos acima, na população aqui estudada, observa-se na Tabela 10 as porcentagens de risco de deficiência de ferro dos escolares.

Nota-se, por esse critério, que o grupo de adolescentes femininas é o de maior risco à deficiência de ferro $(29,5 \%)$. O grupo de 6 a 8 anos, no qual se encontram as maiores prevalências de anemia, segundo o limite inferior de $12 \mathrm{~g} / \mathrm{dl}$ recomendado pela OMS, apresentou, por esta proposta (abaixo de 10,9 $\mathrm{g} / \mathrm{dl}$ ), as menores porcentagens da população em risco de deficiência de ferro $(7,7 \%$ dos meninos e $5,2 \%$ das meninas. (Tabela 9).

Tabela 9 - Distribuição percentual dos escolares segundo risco de deficiência de ferro, por idade e sexo. Município de Santos/SP., 1996.

\begin{tabular}{|c|c|c|c|c|}
\hline \multirow[t]{2}{*}{ Idade(anos) } & \multicolumn{2}{|c|}{$\mathrm{X}$ - 1 DP (risco 20\%)* } & \multicolumn{2}{|c|}{$\mathrm{X}-11 / 2$ DP (risco $75 \%)^{*}$} \\
\hline & $\mathbf{M}$ & $\mathbf{F}$ & $\mathbf{M}$ & F \\
\hline 6卜--- 8 & 12,9 & 11,9 & 7,7 & 5,2 \\
\hline 9 ト- 12 & 19,7 & 22,4 & 5,6 & 15,8 \\
\hline 13 ト-- 16 & 10,7 & 38,6 & 8,9 & 29,5 \\
\hline
\end{tabular}

* Proposto por VITERI e col. (1972)

Vale a pena ressaltar que não existe consenso para o diagnóstico da anemia e/ou deficiência de ferro. O próprio DALLMAN (1996) em publicação recente, propõe o limite inferior de $11,5 \mathrm{~g} / \mathrm{dl}$ para crianças de 5 a 10 anos, de $12 \mathrm{~g} / \mathrm{dl}$ para maiores de 11 anos e de $13 \mathrm{~g} / \mathrm{dl}$ para meninos de 15 a 19 anos. 
Utilizando, para a população deste estudo, o ponto de corte de $11,5 \mathrm{~g} / \mathrm{dl}$, proposto por Dallman, para a faixa etária de 5 a 10 anos, como limite inferior do valor médio normal, as prevalências estimadas ficam em $8,6 \%$ para Região da Orla, 11,2\% para Região Central, 23,5\% para Região Noroeste e 14\% para o Morro.

Ficam evidentes, com esses resultados, que a anemia deve ser considerada como problema de saúde pública entre as crianças de Santos. Note-se que ela esteve presente em $20,89 \%$ da população estudada e a prevalência variou com a idade e com a região geográfica da escola. As regiões noroeste e morro, consideradas as mais carentes, conforme indicadores sócio-econômicos, apresentaram em crianças das $1^{\text {as }}$ séries as prevalências mais altas: $42,42 \%$ e $42,02 \%$ (Tabela 7 ).

A escassez de dados epidemiológicos sobre anemia para esse grupo etário, no Brasil, dificulta a análise comparativa dos resultados encontrados neste trabalho. Entretanto, estudo semelhante realizado em amostra de escolares ingressantes na rede pública de ensino do município de Osasco, em São Paulo, em 1991, encontrou resultados de prevalência de anemia bem mais alarmantes do que estes achados em Santos: $51 \%$ das crianças ingressantes tinham hemoglobina abaixo de $12 \mathrm{~g} / \mathrm{dl}$ (STEFANINI e col., 1995).

A escolaridade dos pais utilizada como marcador social, em ambos os municípios estudados, definiu um perfil mais favorável ao município de Santos onde $59,1 \%$ da população estudada tinha escolaridade de ginásio completo ou mais, enquanto a do município de Osasco, apenas $22,5 \%$ completara o ginásio, ( $8^{\mathrm{a}}$ série).

Como a anemia está mais associada às condições sócio-econômicas desfavoráveis, a presença maior desse quadro em Osasco pode ser explicada, em parte, por diferenças nessa distribuição. Mesmo o perfil antropométrico dos escolares do município de Osasco, 
foi um pouco pior, tendo apresentado déficits do crescimento em $4 \%$ (abaixo de -2 escores Z) da amostra, quando utilizado o indicador altura/idade.

De qualquer forma os estudos de prevalência da anemia realizados no período de quinze anos. (VANNUCCHI e col., 1992), como já mencionado, mostram uma tendência de crescimento, diferentemente do que vem ocorrendo com a desnutrição proteíco-calórica que apresentou redução em mais de 60\% no mesmo periodo (MONTEIRO e col., 1995).

Os resultados do estudo de prevalência da anemia ferropriva em escolares da rede de ensino do município de Santos, São Paulo, vêm confirmar a hipótese de sua presença, de forma preocupante, também nas crianças com mais de 6 anos de idade, exigindo especial atenção do poder público.

Mais preocupantes se tornam esses resultados, ao se referirem à Santos que, conforme algumas informações, já mencionadas na Metodologia, em função da priorização das políticas sociais adotadas nos últimos anos, apresenta situação privilegiada, em relação a outros municípios, quando são comparados indicadores sociais e de evasão escolar, renda média dos chefes de família, mortalidade infantil, entre outros.

Como foi comentado na Introdução deste trabalho, o modelo de determinação da anemia ferropriva está diretamente ligado ao consumo insuficiente de alimentos fontes de ferro.

Retomando este aspecto, com a finalidade de analisar as possibilidades de atuação do poder público no sentido de melhorar esse quadro confirmado de anemia existente na população, torna-se relevante acrescentar informações ligadas especificamente ao consumo do ferro.

A análise de estudos de consumo e despesa familiar com alimentos nas áreas metropolitanas, realizados em três momentos no Brasil, o primeiro, em 1961/62, da 
Fundação Getúlio Vargas (1970), o segundo, em 1974/75, mais abrangente, e único a pesquisar o consumo alimentar, o Estudo Nacional de Despesa Familiar (FUNDAÇÃo IBGE, 1977) e o terceiro, em 1987/88 (FUNDAÇÃO IBGE, 1991), mostra a diminuição da participação de alimentos ricos em ferro na alimentação. (Figura 5)

Figura 5 - Participação de alimentos fontes de ferro em estudos de consumo alimentar de regiões metropolitanas

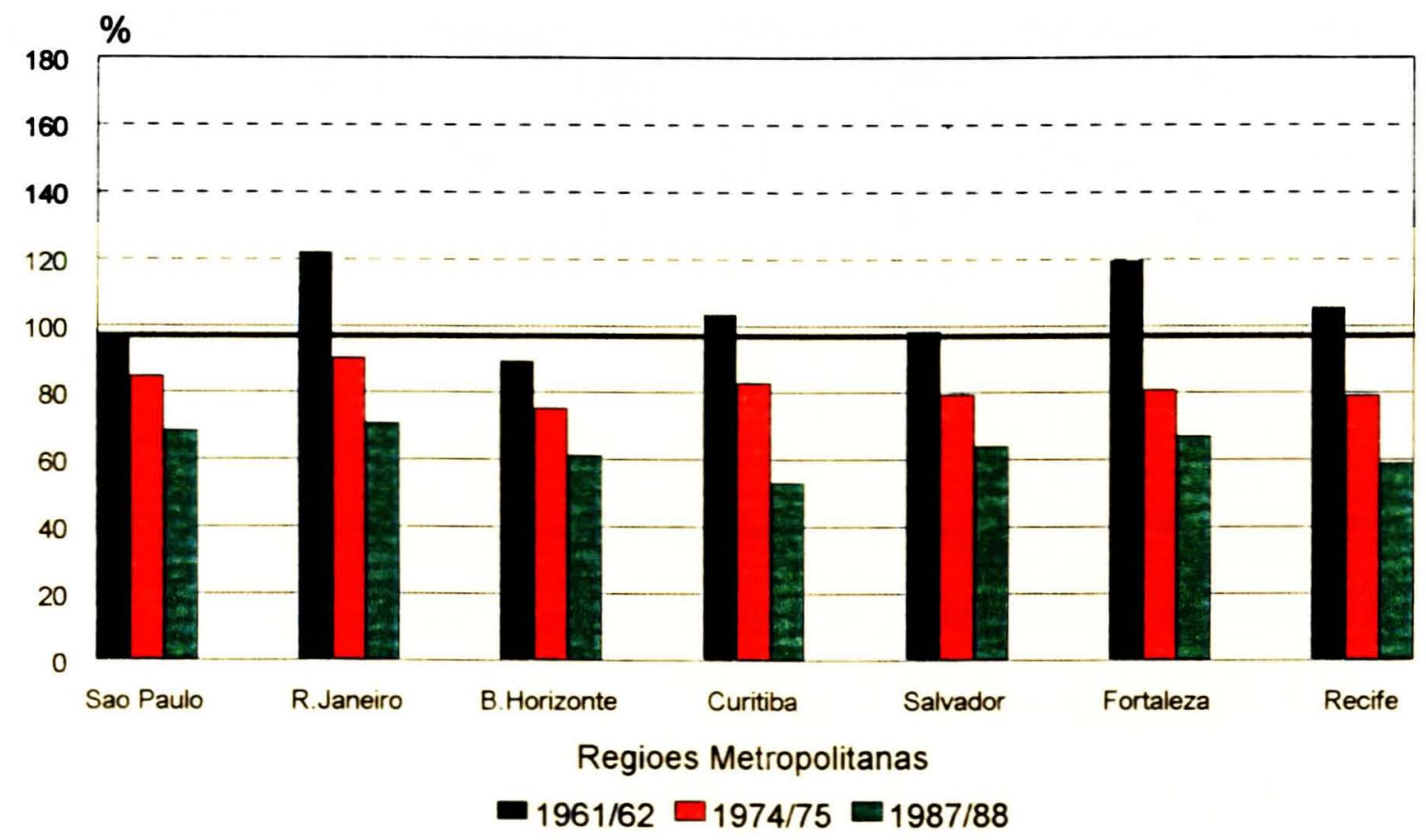

Analisando a composição das cestas de alimentos, nos três momentos, observou-se queda da ingestão de ferro que pode ser explicada por mudanças nas práticas alimentares da população; houve a substituição do feijão, principal fonte desse mineral, por outros alimentos que não o contém. Embora tenha ocorrido aumento do consumo de aves, houve diminuição do consumo total das carnes, no periodo estudado, uma vez que as demais carnes (bovinos, suinos, peixes e vísceras) também apresentaram seu consumo diminuido, restringindo a ingestão do ferro heme. Além da diminuição do ferro total da dieta, sua densidade (mgFe/1000kcal) também diminuiu: há menor proporção de alimentos fontes 
desse nutrientes no dia alimentar do brasileiro. Além disto, a maior proporção do ferro consumido atualmente é de origem vegetal, e sua absorção não vem sendo facilitada pela presença de vitamina $\mathrm{C}$, veiculada por hortaliças cruas e/ou frutas, às refeições, devido as alterações dos hábitos de consumo (SZARFARC, STEFANINI e LERNER, 1995).

Em inquéritos alimentares recentes, também têm sido observadas essas alterações: o jantar ou o almoço, composto por arroz, feijão e outros alimentos como carnes ou ovos e verduras, vem sendo substituído por uma refeição rápida tipo “lanche” (LERNER, 1994).

HOFFMAN (1995), também aponta a diminuição do consumo do feijão fonte de ferro da maior relevância ao longo das décadas de 70 e 80 no Brasil, nas áreas rurais e principalmente nas urbanas, associada às mudanças nos hábitos alimentares. Embora as necessidades de ferro sejam as mesmas hoje do que outrora, os aportes alimentares são menores em razão do modo de vida atual.

É importante também acrescentar que houve, nas últimas décadas, significativo avanço no conhecimento dos processos de absorção, metabolismo e interação entre nutrientes, relacionados ao ferro. A absorção e o aproveitamento desse mineral depende das reservas corporais, forma e quantidade disponível nos alimentos e da combinação destes em cada refeição (MONSEN \& BALINTFY, 1982; BAYNES \& BOTWELL, 1990; LAYRISSE e col., 1968).

Considerando esses processos relativamente recentes, bem como, conhecendo o comportamento alimentar, se faz necessário disseminá-los na população e incorporá-los nas definições de políticas públicas que tenham como objetivo melhorar as condições nutricionais e de saúde.

Finalmente, dentro da proposta deste trabalho falta comentar quanto de ferro a merenda escolar fornece, uma vez que, segundo seus objetivos, pretende melhorar as 
condições nutricionais e de saúde dos estudantes, fornecendo de $15 \%$ a $30 \%$ das quantidades diárias recomendadas de calorias e nutrientes.

Voltando ao estudo de caso em Santos, que serviu como exemplo ilustrativo para apontar a existência de um problema nutricional, a anemia ferropriva, verificou-se a composição da merenda escolar.

Em 1996, ano do estudo da prevalência de anemia, o Município de Santos já contava com o Programa de Merenda Escolar descentralizado.

Foi considerada a composição dos cardápios da merenda escolar servidos durante um mês. A maior parte desses cardápios compunha-se de alimentos in natura e contava com alguns formulados. Durante cada semana, eram servidas refeições completas em três dias da semana e, nos outros dois, a merenda se compunha de lanches e refresco. Os cardápios oferecidos durante um mês, bem como a composição energética e de alguns nutrientes podem ser observados no Anexo IV.

Os alimentos fontes de ferro: carnes e derivados estiveram presentes em $50 \%$ das merendas, 9 em 20 dias, na quantidade de $50 \mathrm{~g}$ por merenda; o feijão, fonte de ferro não heme, esteve presente uma vez por semana na quantidade de $30 \mathrm{~g}$ por dia e sempre acompanhado de carne, ou frango ou lingüiça, combinação recomendável para o melhor aproveitamento do ferro. Constatou-se ausência das verduras nos cardápios, provavelmente pela inexistência do hábito de consumo na faixa de idade escolar e pelo tempo gasto em seu preparo. Os legumes, de mais fácil preparo, entraram duas vezes. Apenas uma vez foi oferecida fruta, sendo que os sucos naturais também não fizeram parte do cardápio. Os refrescos que acompanharam os lanches, eram artificiais. 
A FAO/OMS/UNU* (1985) estimam as necessidades médias diárias de energia e de proteínas, por exemplo, para crianças de 7 a 8 anos de idade, em 1880 Kcal e $42 \mathrm{~g}$ respectivamente. As referentes ao ferro variam de $5 \mathrm{mg}$ a $29 \mathrm{mg}$ segundo o potencial biodisponível desse nutriente na dieta e as condições individuais. Conforme indicação do documento "Aplicação das Recomendações Nutricionais Adaptadas à População Brasileira" (VANNUCCHI, 1990), que estima a biodisponibilidade do ferro em 7\%, e utilizando o padrão recomendado pela FAO/OMS/UNU (1985), as crianças de 6 a 11 anos necessitam ingerir $16 \mathrm{mg}$ de ferro por dia.

Analisando as quantidades oferecidas desses três componentes e lembrando que as metas definidas para o PNAE são de atender no mínimo 15\% das necessidades nutricionais de energia e proteína ( $290 \mathrm{Kcal}, 6,3 \mathrm{~g}$ prot.), verifica-se que, quanto a estas, quase a totalidade dos cardápios da merenda do município de Santos ultrapassou esses valores (ANEXO IV). Contudo, em relação ao atendimento do ferro, que deveria oferecer pelo menos $2,4 \mathrm{mg} /$ dia, isto ocorre apenas nos cardápios compostos com arroz, feijão e algum tipo de carne que foram oferecidos sete vezes no mês. Mesmo a presença de ácido ascórbico como estimulador do aproveitamento do ferro não heme, esteve presente em apenas um único cardápio que incluía uma fruta e atendia a $50 \%$ das necessidades recomendadas. Nos demais, esse nutriente esteve praticamente ausente.

Considerando outros nutrientes importantes que podem ser veiculados pela merenda escolar, como a Vitamina A e o cálcio, verifica-se que estão pouco contemplados nos cardápios das escolas do município de Santos. As necessidades desses nutrientes, para essa faixa de idade, são de, aproximadamente, $800 \mathrm{mcg}$ de retinol e de $900 \mathrm{mg}$ de Cálcio; $15 \%$ dessas necessidades correspondem a $120 \mathrm{mcg}$ e $135 \mathrm{mg}$, respectivamente para 7 a 9

\footnotetext{
* UNU - Universidade das Nações Unidas
} 
anos e de 12 a 15 anos. A merenda oferecida durante vinte dias em Santos atendeu essa meta em apenas nove dias para vitamina A e em quatro para o cálcio.

Confirmada a tendência de diminuição do consumo de alimentos fontes de ferro e observada a ampliação do problema da anemia para as idades escolares, é necessário repensar a política de alimentação e nutrição dirigida a esse grupo. O Programa de Merenda Escolar deve assumir o seu papel social, priorizando os nutrientes que são mais dificeis de serem consumidos no cardápio familiar.

As dificuldades encontradas para suprir as deficiências de ferro e de outros nutrientes na dieta normal, principalmente em população de baixo nível sócio-econômico que tem maior monotonia na alimentação, apontam para a necessidade de priorizá-los na composição da merenda.

As medidas para aumento do ferro biodisponível da dieta podem ser resumidas em três: aumento do consumo habitual de alimentos fontes do mineral, mudança de práticas alimentares que levem à combinação dos alimentos fontes com aqueles que favorecem sua absorção, e fortificação de alimentos com ferro. Essas medidas necessariamente acompanhadas de programas educativos e informativos paralelos podem ser também incorporadas à merenda escolar.

Os alimentos fontes de ferro mais importantes são as carnes e o feijão. Aumentar o consumo de carnes e feijão da merenda escolar não é tão simples; vários aspectos precisam ser considerados: adequação do horário a ser oferecida uma refeição completa; tempo que a criança dispõe para consumir a merenda; locais de preparo e distribuição; recursos humanos suficientes e preparados; utensílios e custo. Todos esses pontos podem variar entre os municípios e entre as escolas. Santos, por exemplo, ofereceu esse tipo de refeição, apenas uma vez por semana. 
Quanto à segunda medida para aumentar o consumo do ferro, isto é, mudanças das práticas alimentares, é necessário introduzir mais frutas e combinar melhor os alimentos. $\mathrm{O}$ ferro não heme do feijão necessita da carne ou da vitamina $\mathrm{C}$ para melhorar sua biodisponibilidade. Uma sopa de feijão por exemplo, não é fonte de ferro quando oferecida sem outro alimento como carne ou alimento fonte de vitamina $\mathrm{C}$.

A terceira medida, a fortificação de alimentos, é um dos caminhos mais eficazes na prevenção e controle da deficiência de ferro, seja para a população em geral, seja para grupos especificos (COOK \& REUSSER, 1983; INAN, 1986; DALLMAN, 1989).

O desenvolvimento de produtos fortificados, entretanto, esbarra em várias dificuldades como, a identificação de um alimento viável de ser fortificado, a fórmula do suplemento adequado para proporcionar biodisponibilidade aceitável, sem alterações das qualidades organolépticas e que tenha um tempo de prateleira compatível com sua distribuição e consumo habituais.

A fortificação de alimentos com ferro apresenta dificuldades adicionais específicas, uma vez que, as formas biodisponíveis do mineral são quimicamente reativas e tendem a produzir alterações indesejáveis nos alimentos aos quais é adicionado.

No Brasil, os alimentos "in-natura" contribuem com a maior parte dos itens que compõem o cardápio nacional, dificultando assim a escolha daqueles viáveis à fortificação. Dentre os processados, por sua vez, alguns como o pão, por exemplo, não são consumidos por crianças de baixa idade, que são as mais expostas ao risco de anemia e as crianças maiores não o consomem em quantidades homogêneas; já o açúcar, de uso amplo, apresenta dificuldades técnicas para sua fortificação.

Registram-se diversas experiências com fortificação de alimentos no Brasil. Entre estas, podem ser citadas as realizadas por grupo de estudos formado por pesquisadores do 
Instituto de Saúde, da Faculdade de Saúde Pública e da Faculdade de Ciências Farmacêuticas da USP, que fortificou alguns produtos e avaliou sua aceitação e eficácia através de intervenção em escolares; os alimentos experimentados, por esse Grupo, com a fortificação, eram veiculados pelo Programa de Merenda Escolar. Foram avaliados: pó para refresco com sulfato ferroso e vitamina $\mathrm{C}$; barrinha de cereais com sulfato ferroso (SZARFARC e col., 1994); biscoitos enriquecidos com sulfato ferroso; biscoito com concentrado de hemoglobina bovina, fórmula idealizada no Chile, adaptada ao Brasil por NOGUEIRA \& COLLI (1992) e avaliado em escolares do $1^{\circ}$ grau por SZARFARC e col., (1994).

Os resultados desses estudos, embora desenvolvidos durante tempo limitado, são favoráveis à utilização de alimentos fortificados, como medida preventiva da carência de ferro; mostraram que a fortificação é uma alternativa eficaz.

É provável que a utilização de produtos fortificados no Programa de Merenda Escolar, o qual se distingue de outros programas de suplementação pela continuidade, amplitude de cobertura, tempo de permanência e oportunidade de consumo quase diário, seja uma intervenção eficaz no controle de deficiências nutricionais específicas no grupo atendido.

Contudo, em vista das experiências anteriores com formulados produzidos especialmente para atender ao programa, cuja aceitação e eficácia não eram consideradas, a introdução de alimentos fortificados de forma quase que compulsória, parece não ser a melhor opção.

Há necessidade de decisão política, legislação própria e bem cuidada para a fortificação de alimentos, apoio da indústria para a produção de alimentos enriquecidos sem alteração significativa nos preços, e amplo trabalho de conscientização e 
esclarecimentos da população sobre práticas alimentares recomendáveis para prevenir a carência de ferro ou de outros nutrientes.

Existindo alimentos fortificados disponíveis no mercado, tanto a população em geral, como os responsáveis pela compra dos produtos para a merenda escolar, poderão compor a alimentação de forma mais adequada a atender as necessidades de nutrientes específicos.

Enquanto esta possibilidade mais eficaz não existir, há necessidade de revisão dos cardápios que vêm sendo oferecidos, a fim de torná-los mais ricos em ferro.

Essas observações indicam que existe a possibilidade de oferecer merenda escolar que, além de atender às necessidades energéticas durante o período escolar, pode melhorar o valor nutricional oferecido à criança, caso seja composta de alimentos adequadamente combinados.

A preocupação em garantir $15 \%$ ou $30 \%$ das necessidades nutricionais que esteve sempre presente na história do Programa de Merenda Escolar precisa ser revista, frente a grande dificuldade de atendimento das necessidades nutricionais específicas, destacando o ferro, aqui analisado, com a alimentação habitual da população que freqüenta a escola pública. 


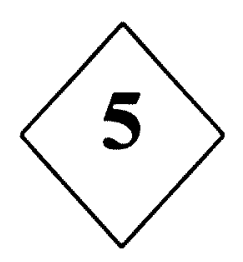

CONSIDERAÇÕES FINAIS 
A reconstituição da história do Programa de Merenda Escolar permitiu conhecer o seu forte componente político e entender que interesses econômicos sempre o cercaram. $O$ conhecimento da sua história pode servir também para aumentar a consciência crítica de quem o executa.

Permite também saber que seu objetivo declarado, em todos os momentos, foi melhorar os níveis de alimentação e nutrição do escolar. Suas metas foram praticamente constantes ao longo de sua existência: fornecer de $15 \%$ a $30 \%$ das necessidades energéticas e protéicas dos escolares de 7 a 15 anos de idade. Lembrando que as necessidades energéticas variam com a idade, o fornecimento mínimo de $15 \%$ de energia significa oferecer refeições com $290 \mathrm{Kcal}^{1}$ para crianças de 7 a 9 anos e com $390 \mathrm{Kcal}$ para meninos de 13 a 15 anos. Essa prática não ocorre: as porções são igualmente preparadas e distribuídas para todas as crianças independentemente do sexo, idade e atividade física. Mesmo esse mínimo de 290 Kcal nem sempre tem sido atingido como observado na composição dos cardápios sugeridos nos diferentes períodos e verificado na merenda escolar do município de Santos. (anexo III e IV).

A presença da desnutrição foi referida desde a introdução do Programa de Merenda Escolar até os dias de hoje, como justificativa para a sua existência e manutenção em todo o território nacional. O Programa quase sempre apontou a merenda como um meio eficaz para diminuir a prevalência da desnutrição. Entretanto, as avaliações elaboradas no decorrer de sua existência, somente levaram em conta os números das merendas distribuídas e de escolas atendidas, não havendo preocupação com a aceitação e eficácia do programa.

\footnotetext{
${ }^{1}$ FAO/OMS/UNU (1985)
} 
Nos últimos vinte anos, a situação brasileira tem apresentado intensas modificações do ponto de vista de crescimento econômico, acompanhado de crescimento da concentração de renda, aumento na oferta de serviços públicos, alterações demográficas seguidas do processo de urbanização e do declínio da fecundidade e paralelamente a esse quadro, reduções expressivas na prevalência da desnutrição.

Essas reduções não ocorreram uniformemente em todo o país, tendo sido relativamente menores na população das Regiões Norte e Nordeste e nas famílias de menor renda, determinando a ampliação das diferenças regionais e sócio-econômicas (MONTEIRO, 1997).

Isto sugere que os resultados sobre a estado nutricional dos escolares do Município de Santos não devem ser generalizados. A situação do estado nutricional apresentada indicou que não ocorreram episódios freqüentes e prolongados de desnutrição e de infecções em idade anteriores, suficientemente graves para interferirem no crescimento das crianças.

Mas, se em Santos a desnutrição não foi significativa nessa idade, o mesmo pode não ocorrer em outras comunidades. Esta análise aponta para a necessidade de definir metas a partir das realidades locais encontradas.

Com relação aos nutrientes específicos a situação se torna mais complexa. Observa-se nos cardápios e nos alimentos oferecidos nás diversas épocas até a atualidade, que nutrientes de importância no quadro epidemiológico da população brasileira, têm sido freqüentemente esquecidos; três deles podem ser destacados nesta análise: o ferro, a vitamina $\mathrm{C}$ e a vitamina $\mathrm{A}$. Os dois primeiros por serem fatores determinantes da anemia e a vitamina $\mathrm{A}$, cuja carência se constitui em um dano social muito presente em áreas do 
Nordeste se estendendo aos bolsões de pobreza em Minas, Rio de Janeiro, São Paulo e outros.

O estudo da prevalência da anemia, realizado como modelo para conhecer, a situação de uma deficiência, apresentou resultados que indicam a necessidade de repensar os objetivos nutricionais do Programa. Mas esses objetivos devem ser revistos com cuidado, uma vez que não será a merenda escolar a política social responsável pela melhoria do quadro de deficiências nutricionais da população de escolares.

A dimensão e a importância política que o Programa detém devem ser canalizados para o melhor atendimento possivel dos objetivos a que se propõe, podendo tornar-se um meio de prevenção de carências nutricionais específicas, aliando-se o fornecimento de merendas de valor nutricional mais adequado às práticas educativas e à conscientização da comunidade envolvida.

A descentralização e municipalização do Programa de Merenda Escolar, iniciada em São Paulo em 1983 e no nível federal em 1985, tem aberto novas perspectivas para a atuação do Programa.

Para ampliar o seu papel social torna-se necessário que o Programa busque sua interlocução com o setor de saúde e com a sociedade. É necessário estabelecer indicadores que permitam avaliá-lo, quantitativa e qualitativamente, de forma contínua e permanente.

Desenvolver um trabalho integrado ề consciente dos profissionais da educação e da saúde com a participação da comunidade, e um caminho para se potencializar o papel das políticas públicas, permitindo que sejam orientadas e priorizadas segundo as realidades locais existentes. 


\section{REFERÊNCIAS BIBLIOGRÁFICAS}


ARRUDA, B.K.G. O Programa Nacional de Alimentação e Nutrição - PRONAN:

suas bases e a participação setorial. Brasília, INAN, 1982.

BARRY, M. Le tiers monde malade du tabac américain. La Recherche, 236(22): 1190-93, 1991.

BATISTA FILHO, M. \& BARBOSA, N.P. Alimentação e Nutrição no Brasil, 1974 1984. Brasília, INAN. 1985. 87 p.

BAYNES, R.D. \& BOTHWELL, TH. Iron deficiency. Ann. Rev. Nutr., 10: 133-148, 1990.

BEHAR, M. La nutricion, un problema social. Bol. Ofic. Sanit. Panamer., 80(6):533-39, 1976.

BEHAR, M. Analisis crítico de los Programas de Nutrición Aplicada en América Latina Rev. Nutr. PUCCAMP, Campinas, 4(42):9-24, 1991.

BREILH, J. Epidemiologia: economia, medicina y politica. Santo Domingo, Ed. Universitaria 1981. $44 \mathrm{p}$.

CAMPINO, A.C.C. org. Economia da alimentação e nutrição (noções básicas). São Paulo, IPE/USP, 1985.

CAMPOS, F.C.B. \& HENRIQUES, C.M.P., org.. Contra a maré à beira-mar. A experiência do SUS em Santos. $2^{a}$ ed., São Paulo, Hucitec,1997. 302 p.

CARVALHEIRO, J. R. Ciências sociais em saúde In: Simpósio sobre a Situação de Pesquisa frente aos Problemas de Saúde, São Paulo, 1991. Anais. São Paulo, 1995.

CASTRO, J. de. A Alimentação brasileira à luz da geografia humana. São Paulo, Brasiliense, 1937.

CASTRO, J. de. O problema da alimentação no Brasil. São Paulo, Brasiliense, 1939.

CASTRO, J. de Introdução. In: Ministério da Educação e Cultura. Programa Nacional de Merenda Escolar, 1954. p. 6. 
CASTRO, J. de. Geografia da fome. 5a ed. São Paulo, Brasiliense, 1957. 292 p.

CASTRO, J. de. Documentário do Nordeste. $\quad 3^{\text {a }}$ ed. São Paulo, Brasiliense, 1965. p. 67-69.

CASTRO, A.M. Nutrição e desenvolvimento: análise de uma política. Rio de Janeiro, 1977. [Tese de Livre Docência - Instituto de Nutrição da UFRJ].

CASTRO, C.M. Fubá, formulados e fundamentalistas. In: CASTRO, C.M. \& COIMBRA, M., org. O problema alimentar no Brasil. São Paulo, Ed. UNICAMP/Almed, 1985. p.165-194.

CASTRO, C.M. \& PELIANO, A.M. Novos alimentos, velhos hábitos e o espaço para ações educativas. In: CASTRO, C.M. \& COIMBRA, M. org. O problema alimentar no Brasil. São Paulo, Ed. UNICAMP Almed, 1985. p. 195-213.

CASTRO, I.R.R. Vigilância alimentar e nutricional: limitações e interfaces com a rede de saúde. Rio de Janeiro, FIOCRUZ, 1995. 108 p.

CASTRO, J. de; BARBOSA, J.J.; SANTOS, W. Relatório do Brasil à Terceira Conferência Latinoamericana de Nutrição - Caracas, $1953 . \quad$ Arq. Bras. Nutr., 10(1):9-43, 1954.

CAVAlCANTI, M.L.F. Bases nutricionais da merenda escolar Anais do I Curso de Saúde Escolar. Departamento de Assistência Escolar, São Paulo,1978. p. 91-112.

CHAVES, N. Ecologia e nutrição. In: CHAVES, N., ed. Nutrição básica aplicada. Rio de Janeiro, Guanabara Koogan, 1978.

COIMBRA, M. Dois modelos de intervenção nutricional no Brasil, PNS e PROAB. In: CASTRO, C. M. \& COIMBRA, M., org. O problema alimentar no Brasil. São Paulo, UNICAMP/Almed, 1985. p. 71-149.

COIMBRA, M.; MEIRE, U.F.P.; STARLING, M.B.L. Comer e aprender. Uma história da alimentação escolar no Brasil. Belo Horizonte, Instituto Nacional de Alimentação Escolar-MEC, 1982. p. 685. 
COMITE MIXTO FAO/OMS DE EXPERTOS EN NUTRICION. Estratégias alimentares y nutricionales en el desarrolo nacional; $9^{\circ}$ informe. Ginebra, Organizacion Mundial de la Salud, 1976. (OMS. Série de Informes Técnicos, 584)

COOK, J.D. \& REUSSER, M.E. Iron fortification: an up date. Am. J. Clin. Nutr., 38:648-59, 1983.

COSTA, D. Tipos de merenda escolar. $2^{\mathrm{a}}$ ed. Brasília, Ministério da Educação e Saúde/Departamento Nacional da Criança, 1950. [Coleção DNCV-70].

COSTA, D. Principais deficiências nutritivas de crianças em idade escolar no Rio de Janeiro. Rio de Janeiro, SAPS, 1960. (Coleção Estudo e Pesquisa Alimentar, 33).

DALLMAN, P.R. Diagnóstico laboratorial da deficiência de ferro no lactente e na criança pequena. Anais Nestlé, 52:18-24, 1996.

DALLMAN, P.R. Iron deficiency: does it matter? J. Intern. Med., 226:367-72, 1989.

DALLMAN, P.R.. \& SIMES, M.A. Percentil curves for haemoglobin and rede cell volume in infancy and childhood. J. Pediatr., 94: 26-31, 1979.

DeMAEYER, E. M.; ADIELS - TEGMAN. M. The prevalence of anaemia in the world. Wld. HIth. Statist. Quant., 38: 302-16, 1985.

DeMAEYER, E.M. Preventing and controlling iron deficiency anaemia through primary health care. Geneva, World Health Organization, 1989. 58 p.

EGAN, M.C. Public health nutrition: a historical perspective. J. Am. Diet. Assoc. 94(4): 298-304, 1994.

FAO/OMS/UNU. Necessidade de energia y proteinas. Informe de uma reunião consultiva conjunta FAO/OMS/UNIV de expertos, OMS. Ginebra, 1985. (Série de Informes Técnicos, 724).

FERREIRA, A.L.S.S.; ALMEIDA, M.C ; PETRUCCI, V.A. Santos: o desafio de ser governo. São Paulo, Polis, 1994. (Publicações Pólis, 18). 
FONSECA, J.P. Merenda Escolar: uma contribuição ao estudo. São Paulo, 1988. [Tese de Doutorado - Faculdade de Educação da USP].

FRANCO, G. Tabela de composição química dos alimentos. $8^{\text {a }}$ ed. Rio de Janeiro, Atheneu. $1987.230 \mathrm{p}$.

FRENK, J.; FREJKZ, T.; BOBADILA, J.L.; STERN, C.J.; LOSANO, R.; SEPÚLVEDA, J.; JOSÉ, M. La transición epidemiologica en América Latina. Bol. Ofic. Sanit. Panamer., 111(6): 485-96, 1991.

FUNDAÇÃO DE ASSISTÊNCIA AO ESTUDANTE. Planejamento da Alimentação Escolar. Diretoria de Apoio Alimentar e Nutricional - FAE. Brasília, 19948 p. (mimeografado)

FUNDAÇÃo DE ASSISTÊNCIA AO ESTUDANTE. Descentralização do Programa Nacional de Alimentação Escolar: Relatório de Atividades 93/94. Brasília, FAE, 1996. $72 \mathrm{p}$.

FUNDAÇÃO GETULIO VARGAS. Food consumption in Brasil. Family budget surveys in the early 1960' s. U.S. Department of agriculture; Economic research service. Israel program for cientific translation, 1970.

FUNDAÇÃO IBGE. Consumo alimentar. Estudo Nacional de Despesa Familiar. ENDEF: dados preliminares. Regiões I,II,III,IV e V, Rio de Janeiro, 1977.

FUNDAÇÃO IBGE. Estudo Nacional de Despesa Familiar - ENDEF. Rio de Janeiro, 1977.

FUNDAÇÃO IBGE. Tabela de composição de alimentos. ENDEF. Rio de Janeiro, 1985 v.3, t.1.

FUNDAÇÃO IBGE. Pesquisa de orçamentos famíliares -POF, 1978/1988. Rio de Janeiro, 1. 1991.

FUNDAÇÃO IBEG/UNICEF. Perfil estatístico de crianças e mães no Brasil. Aspectos de saúde e nutrição de crianças no Brasil, 1989. Rio de Janeiro, IBGE, 1992. $130 \mathrm{p}$. 
GOLDENBERG, P. Repensando a desnutrição como questão social. $2^{\mathrm{a}}$ ed. São Paulo, ed. UNICAMP/Ed. Cortez, 1989. (Série Pesquisas)

GÓMEZ, F. et al. Mortaly in second and third degree malnutrition. J. Trop. Pediatr., 2:77-83, 1956.

HALlberG, L. Bioavailability of dietary iron in man. Ann. Rev. Nutr. 1: 123-47, 1981.

HALLBERG, L. \& ROSSANDER L. Absortion of iron from Westerm - type lunch and dinner meals. Am. J. Clin. Nutr. 35:502-509, 1982.

HOFFMANN, R. A diminuição do consumo de feijão no Brasil. XV reunião anual do consórcio das instituições brasileiras de alimentação e nutrição. SIBAN. São Paulo, 1995. p. 6-15.

INSTITUTO NACIONAL DE ALIMENTAÇÃo E NUTRIÇÃO. Sub Programa: Assistência Alimentar e Educação Nutricional ao Escolar. I Programa Nacional de Alimentação e Nutrição. Brasilia, 1973. p.10-12.

INSTITUTO NACIONAL DE ALIMENTAÇÃO E NUTRIÇÃO. Programa Nacional de Alimentação e Nutrição - PRONAN. Brasília, 1975.

INSTITUTO NACIONAL DE ALIMENTAÇÃO E NUTRIÇÃO. Considerações sobre anemia nutricional. Brasília, D.F., 1986. 29 p.

INTERNATIONAL NUTRITION ANEMIA CONSULTATIVE GROUP (INACG). Guidelines for the eradication of iron deficiency anemia. Washington, D.C., 1978. $29 \mathrm{p}$.

INTERNATIONAL NUTRITION ANEMIA CONSULTATIVE GROUP (INACG). The design and analysis of iron supplementation trials. Washington, D.C., 1984.

JONSSOM, U. As causas da fome. In: VALENTE, F.L.S., org. Fome e desnutrição, determinantes sociais. São Paulo, Cortez, 1986. p. 48-65. 
KAYANO, J.; HEIMANN, L.S.; LUÍS, O.;ESCUDER, M.M. Perfil de condições de vida e saúde: análise comparativa dos grandes municípios de São Paulo. São Paulo, Instituto de Saúde, 1995. [Relatório].

LAYRISSE, M.; MARTÍNEZ-TORRES, C.; ROCHE, M. Effect of interation of various foods on iron absorption. Amer. J. Clin. Nutr., 21:1175-83, 1968.

LERNER, B.R. A alimentação e a anemia carencial em adolescentes. São Paulo, 1994. [Tese de Doutorado - Faculdade de Saúde Pública da USP]

MARTÍNEZ-TORRES, C. \& LAYRISSE, M. Absorcion del hierro de los alimentos. Enriquecimento de los alimentos con hierro. Acta Cient. Venezolana, 23 (supl. 3):201-207, 1972.

MARTINS, I.S. A dimensão biológica e social da doença. São Paulo, 1985. [Tese de Livre Docência - Faculdade de Saúde Pública da USP].

MASSEY, A.C. Microcytic anemia. Differential diagnosis and management of iron deficiency anemia. Med. Clin. North Am., 76, 549-66, 1992.

MINISTÉRIO DE EDUCAÇÃO E CULTURA/MEC. Campanha Nacional de Alimentação Escolar - CNAE. Instruções para a instituição do setor regional da CNAE, São Paulo, Nestlé, 1971. 78 p.

MONSEN, E.R. \& BALINTFY, J.F. Calculating dietary iron bioavailability: refinement and computerization. J. Amer. Diet. Ass., 80:307-11, 1982.

MONTEIRO, C.A. O panorama da nutrição infantil nos anos 90. UNICEF. Cadernos de Políticas Sociais, ago 1996. 17 p [Série Documentos para discussão n. ${ }^{\circ}$ 1]

MONTEIRO, C.A.; BENÍCIO, M.H.D.'A; GOUVEIA, N.C. Saúde e nutrição das crianças brasileiras no final da década de 80. In: Fundação IBGE. Perfil estatístico de crianças e mães no Brasil 1989. Rio de Janeiro, Departamento de Estatísticas e Indicadores Sociais, 1992. p. 19-42. 
MONTEIRO, C.A.; BENICIO, M.H.D'A.; FREITAS, I.C.M. Melhoria em indicadores de saúde associados à pobreza no Brasil dos anos 90: descrição, causas e impacto sobre desigualdades regionais São Paulo, Núcleo de Pesquisa Epidemiológicas em Nutrição e Saúde (NUPENS)/Faculdade de Saúde Pública/Universidade de São Paulo, outubro de 1997. [Série a Trajetória do Desenvolvimento Social no Brasil].

MONTEIRO, C.A.; BENICIO, M.H.D'A.; IUNES, R.F.; GOUVEIA, N.C. \& CARDOSO, M.A.A. Evolução de desnutrição infantil. In: MONTEIRO, C.A. org. Velhos e novos males da saúde no Brasil. A evolução do país e suas doenças. São Paulo, Hucitec/Nupens/USP, 1995.

MORAES, M. L. N. Adequação das merendas às necessidades do escolar [Palestra]. Encontro Técnico-Científico de Alimentação. Associação das Indústrias da Alimentação ABIA, 54, jan/1981, p.30-31.

NATIONAL CENTER FOR HEALTH STATISTICS (NCHS). Growth curves for children, Birth-18 years, United States. Vital Hlth.Stat., 11(165): 1-74,1977.

\section{NEVES, L. A assistência social ao escolar e a Lei de Diretrizes e Bases da Educação}

Nacional. Brasília Conselho Federal de Educação, 1965. p. 63.

NOGUEIRA, N.N.; COLI, C.; COZZOLINO, S.M.F. Controle da anemia ferropriva em Pré-Escolares por meio da fortificação de alimento com cencentrado de hemoglobina bovina (estudo preliminar). Cad. Saúde Públ., Rio de Janeiro, 8(4): 459-465, 1992.

NUSSENZWEIG, I.; NATALE, A.; MALHEIRO, M.E.N.; MALACO, M.M.L. Prevalência de anemia e de parasitoses intestinais em escolares do Município de São Paulo. Rev. Paul. Med., 100(2): 32-38, 1982.

NUTTI, M.R. Análise do sistema de alimentação escolar em 5 municípios do Estado de São Paulo. Universidade Estadual de Campinas - Faculdade de Engenharia de Alimentos, Campinas, 1986. [Dissertação de Mestrado].

OFICINA SANITÁRIA PANAMERICANA. Terceira Conferência sobre los problemas Nutricion en la America Latina - Caracas, Venezuela, FAO/OMS, WASHINGTON, D.C., 1954 (Publicaciones Científicas, $\mathrm{n}^{\circ} 12$ ). 
OLSHANSKY, S.J. \& AULT, B.A. The fourth stage of epidemiologic transition: The age of delayed degenerative diseases. The Milbank Memorial Fund Quartely, New York, 64(3): 355-91, 1986.

OMRAN, A.R. The epidemiologic transition - a theory of the epidemiology of population change. The Milbank Memorial Fund Quarterly, New York, 49(4): 509-38, 1971.

ORGANIZACION MUNDIAL DE LA SALUD. Anemias Nutricionales. Ginebra, 1968. 40 p. (OMS Serie de Informes Técnicos, 405)

ORGANIZACION MUNDIAL DE LA SALUD. Informe de la Reunión de Ministros de Saúde de las Americas. Ginebra, 1972.

ORGANIZACION MUNDIAL DE LA SALUD. Lucha contra la anemia nutricional, especialmente contra la carencia de hierro. Ginebra, 1975. 71 p. (Serie de Informes Técnicos, 580).

ORGANIZACION MUNDIAL DE LA SALUD. Informe de la Conferencia Internacional sobre Atencion Primaria de Salud, Alma-Ata, URSS, 6-12 sep 1978, Ginebra, 1978.

PELIANO, A.M.M. Os programas de alimentação e nutrição para mães e crianças no Brasil, IPEA, 199228 p. (Texto para discussão n. ${ }^{\circ} 253$ ).

PELIANO, A.M. \& BEGHIN, N. Os programas federais de alimentação e nutrição no início da década de 90. Brasilia, IPEA, abril,1994. [mimeografado].

POLLITT, E; SACO-POLLITT, C; LEIBER, RL; VITEI, F.E. Iron deficiency and behavioral development in infants and pre-school children. Am J Clin Nutr.; 43:555-65, 1986.

PRODUTOS E NUTRIÇÃO - Funções de nutrição e seus últimos progressos - XVI/XVII , ano IV, mar/abr, 1970 - Artigos: Diagnósticos da Situação alimentar no Brasil. p. 16 a 41. e "Pó de carne" p. 7 a 11. 
PUFFER, R.R.; SERRANO, C.V. Características de la mortalidad en la niñez. Washington, D.C., Organización Panamericana de la Salud, 1973 (OPAS - Pub. Cientif., 262).

REPARTIÇÃO INTERNACIONAL DO TRABALHO-R.I.T. Inquéritos sobre a alimentação nos países americanos: Resultados, Métodos. In: Conferência Sanitária Pan-Americana, Rio de Janeiro, 1942. Rio de Janeiro, 1943. 84 p.

RITCHIE, JEAN A.S. Estudiemos la nutrición: un segundo estudio sobre sistemas y técnicas. Roma, FAO, 1968. 287 p. [FAO: Estudos sobre nutricion, 20].

ROSEN, G. Uma história da Saúde pública. trad: Marcos Fernando da Silva Moreira \& José Ruben de Alcântara Bonfim. São Paulo, HUCITEC/Ed. da Universidade Estadual Paulista, Rio de Janeiro Associação Brasileira de Pós-Graduação em Saúde Coletiva,1994. $423 . p$

ROSENBURG, C.P. Aspectos conceituais e operacionais do Programa de Alimentação Escolar da Prefeitura do município de São Paulo", Semana de Debates sobre Alimentação Escolar, Câmara Municipal de São Paulo, SP, dez/1973. [mimeografado].

ROSENBURG, C.P. Merenda escolar e crescimento. São Paulo, 1972. [Tese de Doutorado - Faculdade de Saúde Pública da USP]

SANTOS, W. \& PAES, J.D., org. Cartilha da Merenda Escolar. $2^{\mathrm{a}}$ ed. Rio de Janeiro Ministério da Educação e Cultura, 1956.

SANTOS, W.J \& PAES, J.D. Cartilha de desayunos escolares. México, Centro Regional de Ayuda Tecnica, Agencia para el Desarrollo Internacional (AID), 1963. $42 \mathrm{p}$.

SCRIMSHAW, N. S.; TAYLOR, C. E.; GORDON, J. E. Nutrición y infecciones: su accion reciproca. Ginebra, Organización Mundial de la Salud, 1970 (Série de Monografias, 57). 
SECRETARIA DE ESTADO DA EDUCAÇÃO. Merenda escolar: manual de orientação. São Paulo. Departamento de Suprimento Escolar, 1996.

SHRIMPTOM, R. Ecologia da desnutrição na infância: análise da evidência das relações entre variáveis sócio-econômicas e estado nutricional. Brasília, CNRH/IPEA, 1986.

SILVA, M.V. A Trajetória do Programa de Merenda Escolar (1954-1994) e o estado nutricional de crianças brasileiras. Cadernos de Nutrição, 11:31-49, 1996.

SILVA, M.V. Contribuição da merenda escolar para o aporte de energia e nutrientes de escolares do ciclo básico. Rev. Nutr. PUCCAMP, 9(1):9-35, 1996.

SOUZA, D.N.P. Discurso de encerramento da semana de debates sobre Alimentação escolar (Secretário de Educação e Cultura do município de S.Paulo) Câmara Municipal de São Paulo, dez, 1973. [mimeografado].

STECKEL, A; AMAR, M.; PIZARRO, F; CALVO, E; CHADUD,' P; HERTRAMPF, E; LLAGUNO, S; OLIVARES, M. Nutritional significance of interactions between iron and food components. Arch. Lat. Amer. Nutr., 33:33-41, 1983.

STEFANINI, M.L.R. Programas de suplementação alimentar: uma reflexão sobre o assunto. São Paulo, 1987. [Dissertação de Mestrado - Faculdade de Saúde Pública da USP].

STEFANINI, M.L.R.; COLLI, C.; LERNER, B.R.; LEI, D.L.M.; CHAVES, S.P.; DI PIETRO, M.S.; OLIVEIRA, A.A.M.; SZARFARC, S.C. Anemia e desnutrição em escolares da rede pública do município de Osasco, São Paulo - Brasil. Cad. Saúde Públ., Rio de Janeiro 11(3): 439-447, 1995.

STEFANINI, M.L.R.; LERNER, B.R.; LEI, D.L.M.; CHAVES, S.P. Fome e política: história, implantação, desenvolvimento, avaliação e implicações de um programa federal de suplementação alimentar no Estado de São Paulo. São Paulo, Instituto de Saúde, 1994. (Série Políticas Públicas em Saúde, 1) 59 p. 
SZARFARC, S. C. Prevalência da anemia nutricional entre gestantes matriculadas nos centros de saúde do Estado de São Paulo. São Paulo, 1989. [Tese de Livre Docência-

SZARFARC, S.C.; LERNER, B.R.; COLLI, C., CHAVES, S.P.; LEI, D.L.M.; STEFANINI, M.L.R. Intervenção nutricional com alimentos fortificados com ferro em escolares do município de São Paulo. IV Congresso Brasileiro de Saúde Coletiva (ABRASCO); Recife, 1994.

SZARFARC, S.C.; STEFANINI, M.L.R.; LERNER, B.R. Anemia Nutricional no Brasil. Cadernos de Nutrição, 9:5-24, 1995.

TOLEDO, S.A. O problema de nutrição escolar no Estado de São Paulo. (conferência). São Paulo, Serviço de Saúde Escolar, 1973. [mimeografado].

TORRES FILHO, E.T. \& CARVALHO, M.E. Uma análise dos programas de suplementação alimentar nos anos 80: desempenho e formas de organização In: MPAS e CEPAL. Economia e desenvolvimento, vol III, A Política Social em tempo de crise: articulação institucional e descentralização, Ministério da Previdência e Assistência Social - MPAS e Comissão Econômica para América Latina e Caribe CEPAL, cap. IV, p. 358-495, Brasília, 1989.

UCHIMURA, T.T. Anemia e desnutrição em escolares ingressantes nas escolas estaduais de Maringá-PR São Paulo, 1994. [Dissertação de Mestrado - Faculdade de Saúde Pública da USP].

UGÁ, M.A.D. Crise econômica e políticas sociais. Elementos para discussão. Cad. de Saúde Públ, 5(3):305-335, 1989.

UNITED NATIONS, Administrative Committee on Coordination - Subcommittee on Nutrition. Second Report on the World Nutrition Situation. Geneva, 1992. p. 40-8.

UNITED STATES AGENGY FOR INTERNATIONAL DEVELOPMENT. Anemia detection in health services: guidelines for program managers. USAID, Washington, $2^{\mathrm{a}}$ ed, $199637 \mathrm{p}$. 
VANNUCCHI, H.; FREITAS, M.L.S., SZARFARC, S.C. Prevalência de anemias nutricionais no Brasil. Cadernos de Nutrição 4: 7-26, 1992.

VANNUCCHI, H.; MENEZES, E.W.; CAMPANHA, A.O.; LAJOLO, F.M. Aplicação das recomendações nutricionais adaptadas à população brasileira. Cadern. Nutr., São Paulo, 4: 7-26, 1990.

VICTORA, C.G.; VAUGHAN, J.P.; KIRKWOOD, B.R.; MARTINES, J.C.; \& BARCELOS, L.B. Risk factors for malnutrition in Brazilian children: the role of social and environmental variables. Bull WHO 64(2): 299-309, 1986.

VITERI. F.E.; TUNA, V.S.; GUSMÁN, M.A. Normal haematological values in the Central American population. Brit. J. Haemat., 23: 189-204, 1972.

WALTER, T. Impact of iron deficiency on cognition in infancy and childhood. Eur. J. Cli. Nutr., 47:307-16, 1993.

WATERLOW, J. C. Observations on the assessment of protein- energy malnutrition with special reference to stunting. Courrier, 28 (5):455-60, 1978.

WORLD HEALTH ORGANIZATION. Protein Requirements. Geneva, 1965. [Technical Report Series, $\mathrm{n}^{\circ}$ 301]. $72 \mathrm{p}$.

WORLD HEALTH ORGANIZATION. Use and interpretation of anthropometric indicators of nutritional status. Bull. Wld. Hlth. Org., 64(6):929-41, 1986.

ZURAYK, H.J. HALABI, S.; DEEB, M. Measures of social class based on education for use in health studies in developing countries. J. Epidemiol. Comm. Hlth., 41: 173179, 1987. 


\section{LEIS, DECRETOS, E PORTARIAS}

BRASIL, Constituição 1988. Constituição República Federativa do Brasil. Brasília, Senado Federal, 1988 art. 208 cap. III - Merenda Escolar como dever do Estado.

BRASIL, Leis, Decretos, etc.. Decreto ${ }^{\circ} 37.106$ de 31/3/1955: institui a Campanha da Merenda Escolar, Rio de Janeiro, 1955. In: MEC, CNAE, Instruções para a instituição do setor regional da CNAE. Nestlé, $2^{\text {a }}$ ed., São Paulo, 1971.

BRASIL. Leis e Decretos, etc.. Decreto n. ${ }^{\circ} 39.007$ DE 11/04/1956 altera o nome da Campanha de Merenda Escolar para Campanha Nacional de Merenda Escolar. Diário Oficial da União, Brasília, 13 abr. 1956.

BRASIL, Leis, Decretos, etc.. Decreto $n^{\circ} 40.052$ de 1/10/56: criação do Fundo Especial para custear as despesas da Campanha. Diário Oficial da União, Brasília, out 1956.

BRASIL, LEIS, DECRETOS, etc. Portaria n. ${ }^{\circ}$ 388-A de 22/11/1957 dispões sobre finalidade, recursos, organização e competência da Campanha Nacional da Merenda Escolar. In: MEC, CNAE. Instruções para a instituição do setor regional da CNAE. Nestlé, $2^{\mathrm{a}}$ ed, São Paulo, 1971.

BRASIL, Leis, Decretos, etc.. $\quad$ Decreto $n^{0} 56.886$ de 20/9/1965: altera a denominação de CNME para CNAE e amplia do atendimento. Diário Oficial da União, Brasília, parte I, p 1, 26 set. 1965.

BRASIL, Leis, Decretos, etc.. Decreto $\mathrm{n}^{\circ} 5.829$ de 30/11/1972: criação do Instituto Nacional de Alimentação e Nutrição - INAN. Diário Oficial da União, Brasília, nov. 1972.

BRASIL, Leis, Decretos, etc. Decreto $n^{\circ} 72.034 / 73$ - amplia os objetivos da merenda escolar. Diário Oficial da União, Brasília, 1973.

BRASIL. Leis, Decretos, etc.. Decreto $n^{\circ} 72.116$ de 6/2/76 estabelece diretrizes para a ação do governo na área de alimentação e nutrição, aprova o PRONAN e dá outras providências. Diário Oficial da União, Brasília, fev. 1976 
BRASIL, Leis, Decretos, etc. Portaria Ministerial $n^{\circ} 708$ de 22/12/81: criação do Instituto Nacional de Assistência Escolar - INAE, em substituição à CNAE. Diário Oficial da União, Brasília, dez 1981.

BRASIL, Leis, Decretos, etc.. Decreto $\mathrm{n}^{\circ} 23.632$ de 5/7/1985: fixa os valores nutricionais mínimos de Calorias e proteínas do Programa de Merenda Escolar. Diário Oficial da União, Brasília, jul 1985..

BRASIL, Leis, Decretos, etc. Lei $\mathrm{n}^{\circ}$ 8.913, de 12/7/1994: dispõe sobre a descentralização da merenda escolar. Diário Oficial da União, Brasília, 13 jul, 1994.

BRASIL, Leis, Decretos, etc. Portaria 291 de 8/8/96: autonomia para os municípios para composição do cardápio e controle de qualidade. Diário Oficial da União, Brasília, 10 jul. 1996

SÃO PAULO (Estado). Leis, Decretos, etc.. Lei n. $^{0}$ 573/83 - inicio do processo de descentralização do PME em São Paulo. Diário Oficial do Estado de São Paulo, São Paulo,1983.

SÃO PAULO (Estado). Leis, Decretos, etc. Decreto n. ${ }^{\circ} 22758$ de 5/10/84 - criação dos Conselhos Municipais da Merenda Escolar. Diário Oficial do Estado de São Paulo, São Paulo,6 out., 1984.

SÃO PAULO (Estado). Leis, Decretos, etc.. Decreto n. . $^{\circ} 28.170$ de 21/1/88: sistema de Jornada Única para o ciclo básico, São Paulo, 1988. Diário Oficial do Estado de São Paulo, São Paulo, 22, jan, 1998. Brasília,.

SÃO PAULO (Estado). Resolução n. ${ }^{\circ} 62$ de 13/3/89 - fixa para alunos de Jornada Única, valor nutricional mínimo da merenda escolar. Diário Oficial do Estado de São Paulo, São Paulo, mar.1998.

SÃO PAULO (Estado). Decreto n 40685 de 26/2/96: cria o Conselho Estadual de Alimentação Escolar de São Paulo - CEAE. Diário Oficial do Estado de São Paulo, São Paulo, 27, fev. 1996. 
ARQUIVOS BRASILEIROS DE NUTRIÇÃO. 76 volumes editados no período de 1944 a 1968 . Instituto de Nutrição da Universidade do Brasil, RJ.

CAMPANHA NACIONAL DE ALIMENTAÇÃO ESCOLAR - Relatório anual de 1967.

Universidade de São Paulo - Faculdade de Saúde Pública. Normas de referência bibliográficas aplicadas à Saúde Pública. Serviço de Biblioteca e Documentação, São Paulo, 1995 (Serie de Orientação Bibliográfica ${ }^{2}$ ).

Universidade de São Paulo - Faculdade de Saúde Pública. Fontes bibliográficas especializadas em Saúde Pública. Serviço de Biblioteca e Documentação. São Paulo, 1995 (Série de Orientação Bibliográfica n. ${ }^{\circ}$ 1).

Universidade de São Paulo - Faculdade de Saúde Pública. Regras de citação de textos de Saúde Pública. Serviço de Biblioteca e Documentação. São Paulo, 1995 (Série de Orientação Bibliográfica n..$^{\circ}$ ).

Universidade de São Paulo - Faculdade de Saúde Pública. Instruções para apresentação de trabalho acadêmico no campo da Saúde Pública. Serviço de Biblioteca e Documentação. São Paulo, 1995. (Série de Orientação Bibliográfica $\left.n^{\circ} 4\right)$. 


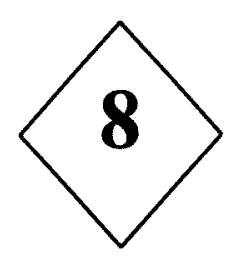

ANEXOS 


\section{A NEXO I}

INSTRUMENTO UTILIZADO NO ESTUDO DE CASO PARA OBTENÇÃO DE INFORMAÇÕES 

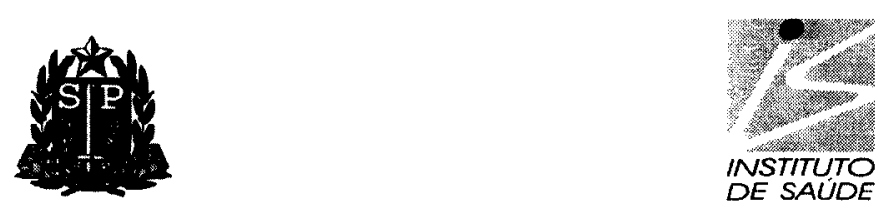

\section{SECRETARIA DE ESTADO DA SAÚDE INSTITUTO DE SAÚDE}

\section{ANEMIA FERROPRIVA: ESTUDO DE PREVALÊNCIA EM ESCOLARES DO $1^{\circ}$ GRAU DA REDE DE ENSINO DO MUNICÍPIO DE SANTOS/SP}

SÃo PAULO, 10 DE JUNHO DE 1.996.

\section{PREZADOS PAIS,}

Estamos verificando nas escolas se as crianças estão com anemia. A anemia é um problema de saúde que está aumentando nos últimos anos. A criança com anemia fica distraída, se cansa com facilidade, não presta atenção, tem dificuldade de aprender e menor resistência às infecções. A anemia pode ser prevenida com alimentação mais adequada. Para orientarmos sobre as medidas a serem seguidas precisamos saber quais são as crianças anêmicas.

Pedimos a sua autorização para realizar o exame que será feito com uma picada de agulha no dedo. O material usado será totalmente descartável. O resultado do exame será enviado à escola.

Caso autorize, por favor preencha os dados abaixo.

Atenciosamente,

MARIA LUCIA ROSA STEFANINI

Coordenadora do Projeto de Anemia

Escola:

Nome Do Aluno:

Série

Esta tomando algum remédio para anemia Não ( ) $\operatorname{Sim}($ )

Qual:

Pai estudou :

até ___érie do $1^{\circ} \mathrm{Grau}$ ou primário

até _série do $1^{\circ} \mathrm{Grau}$ ou ginásio

até _série do $2^{\circ} \mathrm{Grau}$ ou Colegial

$\square$ Não Estudou

Não sabe
Mãe estudou :

até _série do $1^{\circ} \mathrm{Grau}$ ou primário

até __érie do $1^{\circ} \mathrm{Grau}$ ou ginásio

até ___érie do $2^{\circ} \mathrm{Grau}$ ou Colegial

Não Estudou

Não sabe 

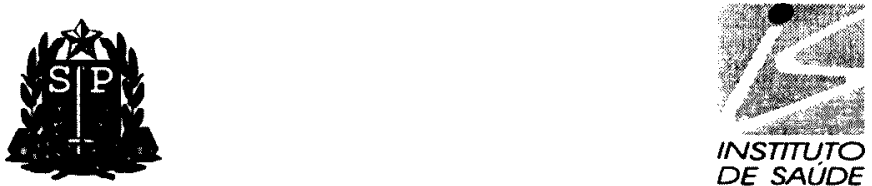

$D E$ SAUUDE

\section{SECRETARIA DE ESTADO DA SAÚDE}

INSTITUTO DE SAÚDE

São Paulo, Outubro de 1996.

\section{IDENTIF :}

NOME :

Peso :

\section{Altura:}

\section{HEMOGLOBINA:}

Como você se lembra, estivemos em sua escola colhendo dados para um estudo sobre ANEMIA. Informamos acima os resultados do seu peso, de sua altura, bem como, da hemoglobina que informa se você está ou não anêmico(a).

O resultado do seu exame de sangue foi "positivo", isto é, você está com anemia.

Recomendamos que procure um serviço de saúde e passe a adotar alguns hábitos na hora de suas refeições, que podem melhorar este problema.

Procure comer alguma verdura de folha escura no almoço ou no jantar, suco de fruta (laranja, limão ou mamão) durante as refeições e/ou uma fruta como sobremesa. Deixe os doces para comer nos intervalos das refeições, não esquecendo de escovar os dentes para evitar as cáries. Se possível, procure ingerir algum tipo de carne, ou mortadela, ou linguiça, ou frango, ou peixe, pelo menos em uma das refeições.

Mostre estes resultados para seu pai ou responsável, e procure seguir as orientações acima.

Agradecemos a sua valiosa colaboração.

Cordialmente, 


\section{A N E X O II}

\section{DECRETO No 37.106 - DE 31 DE MARÇO DE 1955}

(Institui a Campanha de Merenda Escolar)

Portaria n. ${ }^{\circ}$ 388-A de 22 de NOVEMBRO DE 1957

(Regimento da Campanha de Merenda Escolar) 


\section{Decreto n. ${ }^{\circ} 37106$ de 31/03/1955}

\section{Institui a Campanha de Merenda Escolar}

O Presidente da República, usando das atribuições que lhe confere o Art. 87, item I, da Constituição, decreta:

Art. $1^{0}$ - É instituída na Divisão de Educação Extra-Escolar do Departamento Nacional de Educação do Ministério da Educação e Cultura, a Campanha de Merenda Escolar. (3) (9)

Art. $2^{\circ}$ - Cabe à Campanha de Merenda Escolar, dando cumprimento ao que dispõe o item $3^{\circ}$, alínea $b$, Art. $2^{\circ}$, do Regimento aprovado pelo Decreto $n^{\circ} 34.078$, de 6 de outubro de 1953 ; (4) (7) (10)

a) incentivar, por todos os meios ao seu alcance, os empreendimentos públicos ou particulares que se destinem a proporcionar ou facilitar a alimentação do escolar, dando-lhe assistência técnica e financeira;

b) estudar e adotar providências destinadas à melhoria do valor nutritivo da merenda escolar e ao barateamento dos produtos alimentares, destinados ao seu preparo;

c) promover medidas para aquisição desses produtos nas fontes produtoras ou mediante convênios com entidades internacionais, inclusive obter facilidades cambiais e de transporte para sua cessão a preços mais acessíveis.

Art. $3^{\circ}$ - A ação da Campanha se estende a todo Território e será realizada diretamente através da criação de cantinas escolares, ou mediante convênios a serem firmados com entidades particulares.

Art. $4^{0}$ - Os encarregados da Campanha serão atendidos com os recursos orçamentários específicos. (5) (6)

Art $5^{\circ}$ - O Ministério da Educação e Cultura baixará as instruções necessárias à organização da Campanha. 
Art. $6^{\circ}$ - Este decreto entrará em vigor na data de sua publicação, revogadas as disposições em contrário.

Rio de Janeiro, 31 de março de $1955 ; 134^{\circ}$ da Independência e $67^{\circ}$ da República - João Café Filho - Cândido Mota Filho.

Obs.: (3), (4) e (5) Alterados pelo Decreto $n^{\circ} 39.007$ de 11 de abril de 1956, publicado no DO de 13-4-1956.

(6) Alterado pelo Decreto $\mathrm{n}^{\circ} 40.052$, de $1^{\circ}$ de outubro de 1956.

(7) Revogado pelo Art. $3^{\circ}$ do Decreto $\mathrm{n}^{\circ} 37.106$ de 31 de março de 1955, publicado no DO de 2-4-1955.

(9) Alterada a denominação de CME para CNAE, pelo Decreto $\mathrm{n}^{\circ} 56.886$, de 20 de setembro de 1965.

(10) Revogado pelo Art. $2^{\circ}$ do Decreto $\mathrm{n}^{\circ} 45.582$, de 18 de março de 1959. (DO de 2/4/1955) 


\section{PORTARIA N 388-A - DE 22 DE NOVEMBRO DE 1957}

O Ministro do Estado da Educação e Cultura, no uso de suas atribuições, resolve:

$\mathrm{N}^{\circ} 388-\mathrm{A}$ - Nos termos do Art. $5^{\circ}$ do Decreto $\mathrm{n}^{\circ} 37.106$, de 31 de março de 1955, aprovar o anexo Regimento da Campanha Nacional de Merenda Escolar, que substituirá o Regimento aprovado pela Portaria $n^{\circ} 166$, de 2 de junho de 1955. a) Clovis Salgado.

\section{CAPÍTULO I}

\section{Da Finalidade}

Art. $1^{\circ}$ - A Campanha Nacional de Merenda Escolar (CNME), instituída na Divisão de Educação Extra-Escolar do Departamento Nacional de Educação, pelo Decreto $\mathrm{n}^{\circ} 37.106$, de 31 de março de 1955, modificado pelos Decretos $\mathrm{n}^{\circ} 39.007$, de 11 de abril de 1956 e 40.052 , de $1^{\circ}$ de outubro de 1956 , tem por finalidade:

a) incentivar, por todos os meios a seu alcance, os empreendimentos públicos ou particulares que se destinam a proporcionar ou facilitar a alimentação escolar, dando-lhe assistência técnica e financeira;

b) estudar e adotar providências destinadas à melhoria do valor nutritivo da merenda escolar e ao barateamento dos produtos alimentares, destinados a seu preparo;

c) promover medidas para aquisição desses produtos nas fontes produtoras mediante convênios, inclusive com entidades internacionais;

d) organizar e executar planos que visem a difundir e implantar os princípios básicos da boa alimentação.

Art. $2^{\circ}$ - A ação da CNME se estende a todo o Território Nacional e será realizada diretamente através a criação de cantinas escolares ou mediante convênios a serem firmados com entidades públicas ou particulares (Art. $3^{\circ}$ do Decreto $n^{\circ} 37.106$, de 31 de março de 1955). 


\section{CAPÍTULO II}

\section{Dos Recursos}

Art. $3^{\circ}$ - As atividades da CNME serão custeadas com recursos do Fundo Especial, depositados em conta própria, no Banco do Brasil, a ser movimentada pelo Superintendente e constituído de:

a) contribuições que forem consignadas nos Orçamentos da União, Estados, Municípios, entidades para-estatais e sociedades de economia mista;

b) contribuições provenientes de projetos, de acordos, contratos e convênios com entidades públicas e privadas;

c) donativos, contribuições e legados de entidades públicas e particulares;

d) renda do patrimônio sob a guarda e responsabilidade da CNME;

e) todas e quaisquer rendas eventuais.

Parágrafo único - A aplicação desses recursos será feita rigorosamente, de acordo com o Plano de Aplicação apresentado anualmente pelo Superintendente, da CNME, à aprovação do Ministro da Educação e Cultura, no qual serão discriminados os serviços a serem executados e a modalidade de financiamento. (Decreto $n^{\circ} 40.052$, de $1^{\circ}$ de outubro de 1956).

Art. $4^{\circ}$ - A CNME, instituída na Divisão de Educação Extra-Escolar do Departamento Nacional de Educação, do Ministério da Educação e Cultura, de acordo com o Decreto $n^{0} 37.106$, de 31 de março de 1955, modificado pelos Decretos $n^{\circ} 39.007$, de 11 de abril de 1956 e 40.052 , de $1^{\circ}$ de outubro de 1956, será superintendida pelo atual Diretor da referida Divisão. 


\section{CAPÍTULO III}

\section{Da Organização}

Art. $5^{\circ}$ - A CNME terá a seguinte organização:
a) Superintendência;
b) Setor Técnico (ST);
c) Setor Administrativo (SA).

$\S 1^{\circ}$ - Os órgãos das alíneas b e c, deste artigo, serão encarregados, imediatamente subordinados ao Superintendente da CNME;

$\S 2^{\circ}$ - O Superintendente terá para auxiliá-lo diretamente, um secretário e os auxiliares que julgar necessários, requisitados do quadro do pessoal da CNME, através de Portaria, ou colaboradores que, em caráter eventual, participem de projetos de execução de serviços.

$\S 3^{\circ}$ - O Setor Técnico será orientado de preferência, por médico-nutrólogo.

$\S 4^{\circ}$ - Os órgãos das alíneas b e c deste artigo terão seu pessoal fixado pelo Superintendente.

$\S 5^{\circ}$ - A CNME manterá, nas Unidades da Federação, Representantes Regionais que abrangerão um Estado ou um conjunto de Estados limítrofes; por determinação da Superintendência, de acordo com a expansão dos serviços.

$\oint 6^{\circ}$ - A Representação Regional constará de um Representante e, quando necessário, de servidores que poderão ser pertencentes ao quadro da CNME ou a outros órgãos públicos e postos à disposição da mesma, ou ainda das que, a título de colaboração, prestem serviços eventuais.

$\S 7^{\circ}$ - A designação para Representante Regional recairá de preferência, em médico-nutrólogo. 


\section{CAPÍTULO IV}

\section{Da competência dos Órgãos}

\section{1 - Da Superintendência}

Art. $6^{\circ}$ - Ao Superintendente compete:

a) a gestão geral das atividades da CNME, podendo delegar atribuições aos Encarregados dos Setores Técnico e Administrativo, e aos Representantes Regionais;

b) expandir portarias e demais atos que estruturem, organizem e instruam o funcionamento das atividades da CNME;

c) determinar a organização de turmas de trabalho que devem constituir os Setores Técnico e Administrativo, dando-lhe denominação própria;

d) assinar projetos, acordos, contratos e convênios para execução do Programa da CNME, expedir e assinar certificados de habilitação nos Cursos previstos na alínea "e" do artigo $7^{\circ}$;

e) providenciar facilidades cambiais e de transporte para a CNME na forma do Art. $3^{\circ}$ do Decreto $n^{\circ} 37.106$, de 31 de março de 1955;

f) manter entendimentos com todos os órgãos públicos e particulares em proveito da CNME;

g) autorizar a realização de serviços eventuais, por meio de tarefas e pagamento "pro-labore" ou contratos, para execução da CNME;

h) elaborar e submeter à aprovação do Ministro da Educação e Cultura o Plano de Aplicação anual da CNME, na forma do parágrafo único do artigo $3^{\circ}$ destas Instruções;

i) promover e ativar campanhas de obtenção de recursos para o Fundo Especial da CNME; 
j) fomentar a organização de entidades que visem a auxiliar o desenvolvimento do programa da CNME;

k) instituir e incentivar organizações que possibilitem participação do povo em geral no movimento educacional e assistencial desenvolvido pelo CNME, podendo instituir prêmios, diplomas e medalhas em reconhecimento a serviços prestados;

1) movimentar o fundo Especial da CNME no Banco do Brasil;

m) dirigir e fazer um Boletim Informativo que denominar-se-á "Merenda Escolar" para distribuição não só entre as escolas, como também a todos os setores relacionados com a alimentação em geral;

n) inspecionar as atividades da Campanha em todo o Território Nacional, pessoalmente ou por intermédio de representantes para esse fim designados;

o) submeter à aprovação do Ministro da Educação e Cultura, anualmente, a tabela numérica de funções do pessoal da CNME, com as respectivas remunerações, na forma prevista no art. 17 da Lei $n^{0} 1765$, de 18 de dezembro de 1952;

p) admitir ou dispensar o pessoal da CNME;

q) designar os Encarregados dos Setores Técnicos e Administrativos, os Representantes Regionais, o secretário e os auxiliares previstos no parágrafo $2^{\circ}$ do artigo $5^{\circ}$;

r) realizar concorrências e coletas de preços para a aquisição de gêneros e materiais destinados à CNME, bem como para transportes, quando necessários, de acordo com o parágrafo $1^{\circ}$ do art. 10 da Portaria Ministerial $\mathrm{n}^{\circ} 5$, de 6 de janeiro de 1955 ;

s) elaborar e remeter ao Ministro do Estado da Educação e Cultura, o relatório anual das atividades das CNME. 


\section{2 - Do Setor Técnico}

Art. $7^{\circ}$ - Ao Setor Técnico compete:

a) organizar e submeter à aprovação do Superintendente programas referentes à orientação, fiscalização e execução da parte técnica da CNME em todo Território Nacional;

b) apresentar sugestões ao Superintendente quanto aos diversos tipos de merenda, propondo as que deverão ser utilizadas nas diferentes áreas do País, de acordo com o valor nutritivo de seus integrantes e de suas condições de preparo, de palatabilidade, de conservação, de transporte, de aquisição e de distribuição;

c) promover estudos, realizar e incentivar as pesquisas de alimentos e produtos alimentícios, relacionados com preparo das merendas, focalizando seus caracteres fisicos, químicos e físico-químicos;

d) formular instruções para preparação, acondicionamento, transporte, estocagem e distribuição de alimentos no que concerne aos seus aspectos técnicos;

e) ministrar cursos especializados, inclusive os de fim precípuo de dar preparo técnico aos elementos que desempenham diferentes funções e atividades na CNME;

f) proceder à adaptação do pessoal competente do quadro técnico;

g) planejar programa de educação alimentar, através de conferências, palestras, exposições e de outros meios de divulgação, bem como preparar o material didático para essa ação educativa;

h) propor ao Superintendente a realização de congressos nacionais e internacionais, seminários, quinzenas e semanas de educação alimentar no que diz respeito à Merenda Escolar; 
i) propor ao Superintendente a realização de estágios para médicos-nutrólogos e de outras especialidades, dietistas, auxiliares de alimentação, visitadoras, educadoras, assistentes sociais e representantes de outras classes, cujo labor profissional mantenha contato com o problema alimentar;

j) avaliar o estado físico dos escolares, através de estudos, inquéritos e investigações;

k) propor a exposição de formulários para a coleta de informes ligados à nutrição em geral;

1) estudar os mapas e relatórios de controle das atividades da CNME, assim como os formulários de inquérito nutricional, interpretando e propondo a divulgação de suas conclusões e realizando as necessárias estatísticas;

m) apontar as medidas tendentes a corrigir as falhas reveladas pelos inquéritos;

n) elaborar, de acordo com as verbas disponíveis, planos para aquisição e distribuição de alimentos e material didático, bem como para instalação de cantinas escolares;

o) organizar fichário e arquivo de documentação referente ao Setor Técnico da CNME;

p) emitir parecer nos projetos, contratos e convênios a serem firmados com entidades públicas e particulares;

q) preparar e submeter ao Superintendente todo o expediente relativo ao Setor Técnico nas atividades da CNME;

r) organizar e prover o funcionamento das cantinas escolares;

s) propor medidas para orientar, controlar e fiscalizar os trabalhos das Representações Regionais;

t) fornecer ao Setor Administrativo elementos estatísticos para confecção de relatórios. 


\section{3 - Do Setor Administrativo}

Art. $8^{\circ}$ - Ao Setor Administrativo compete:

a) lavrar os atos do pessoal e submetê-los à assinatura do Superintendente;

b) preparar e submeter ao Superintendente todo o expediente relativo ao Setor Administrativo nas atividades do CNME;

c) providenciar, de acordo com o resultado das concorrências e coletas de preços aprovados, a aquisição, o controle, a estocagem e a remessa do material e gêneros alimentícios da CNME, em todo o Território Nacional, mantendo em ordem e em dia a documentação e os registros dessas compras e fornecimentos;

d) executar e manter em dia a contabilização dos fundos da CNME;

e) preparar e apresentar mensalmente ao Superintendente a prestação de contas a ser encaminhada ao Ministro da Educação e Cultura, na forma dos artigos 11 e 12 da Portaria Ministerial no 5, de 6 de janeiro de 1955, publicada no Diário Oficial de 8 do mesmo mês e ano;

f) preparar a prestação de contas anual a ser encaminhada à Divisão de Orçamento, para a aprovação do Ministro da Educação e Cultura;

g) executar os trabalhos de expedição, protocolo e arquivo geral da CNME;

h) providenciar o arrolamento e inventário de todo o material da $\mathrm{CNME}$, em cumprimento aos disposto nos Decretos-leis $n^{\circ} 9.633$, de 22 de agosto de 1946 e 9.824 , de 10 de setembro de 1946 ;

i) promover, após autorização do Superintendente, o expediente relativo a requisições de passagens e transportes;

j) promover elaboração de minutas de projetos, acordos, contratos e convênios; 
k) providenciar os atos de pagamento de pessoal, submetendo-os à aprovação do Superintendente;

1) organizar e manter em dia os assentamentos individuais de pessoal da CNME;

m)organizar o relatório anual das atividades da CNME.

\section{CAPÍTULO V}

\section{Do Pessoal}

Art. 10 - A CNME terá pessoal estabelecido nas tabelas de funções constantes dos planos de trabalho anualmente aprovados.

$\S 1^{\circ}$ - Além do pessoal fixado na tabela de funções, a CNME poderá ter colaboradores eventuais que forem autorizados pelo Superintendente, na forma do artigo $6^{\circ}$, alínea "g", destas Instruções.

$\S 2^{\circ}$ - Poderão ser admitidos para prestação de serviços à CNME, servidores públicos, nos termos do Decreto $\mathrm{n}^{\circ} 36.479$, de 19 de novembro de 1954 .

$\S 3^{\circ}$ - A CNME poderá solicitar aos Governos Estaduais ou Municipais sejam postos à disposição os servidores que tornarem necessários ao desenvolvimento do programa nos respectivos Estados ou Municípios.

\section{CAPÍTULO VI}

\section{Do Horário}

Art. 11 - O horário normal de trabalho da CNME é o estabelecido para os Servidores Públicos em geral, podendo o expediente ser antecipado ou prorrogado, de acordo com a legislação vigente e segundo as conveniências do serviço.

CAPÍTULO VII 


\section{Das Substituições}

Art. 12 - Serão substituídos, nas faltas ocasionais e nos impedimentos transitórios:

a) o Superintendente pelo substituto eventual do Diretor da Divisão de Educação Extra-Escolar;

b) os encarregados do Setor por servidores designados pelo Superintendente.

\section{CAPÍTULO VIII}

\section{Das Disposições Gerais}

Art. 13 - Os casos omissos, relativos a estas Instruções, serão objeto de ato ministerial.

Art. 14 - Estas instruções entrarão em vigor na data de sua publicação ficando revogadas as disposições em contrário.

Rio de Janeiro, 22 de novembro de 1957

ass. Clóvis Salgado

DO de $20 / 1 / 1958$ 


\section{SETOR REGIONAL DA CNAE}

\section{R E G I M E N T O}

\section{TÍTULO I}

\section{Finalidades}

Art. $1^{\circ}$ - O SETOR REGIONAL DA CNAE, dirigido por um Chefe, subordinado diretamente à Representação Federal, é o órgão de representação e execução do Programa da CNAE, em nível regional, no âmbito estadual ou territorial, limitada sua atuação ao que estabelece este Regimento.

Art. $2^{\circ}$ - O Setor Regional utilizar-se-á dos seguintes meios para atingir sua finalidade:

a) celebrar termos de Ajuste;

b) receber e distribuir alimentos e materiais;

c) coletar informações e dados estatísticos;

d) obter recursos oficiais necessários ao Programa;

e) coordenar, orientar, divulgar e fiscalizar as atividades desenvolvidas em sua área;

f) promover a participação da Comunidade no Programa.

\section{TÍTULO II}

\section{Estrutura}

Art. $3^{\circ}$ - Constitui estrutura básica do Setor Regional:

a) chefia;

b) equipes técnica e administrativa. 
TÍTULO III

\section{Atribuições}

Art. $4^{0}$ - Constituem atribuições do Chefe do Setor Regional:

a) representar a CNAE , na área de sua jurisdição;

b) coordenar, dirigir, orientar, fiscalizar e responsabilizar-se pelas atividades do Setor Regional, observadas as normas em vigor;

c) celebrar, de acordo com o padrão adotado pela Representação Federal, Termos de Ajuste com Prefeituras Municipais e outras instituições públicas ou particulares;

d) promover reuniões periódicas com Prefeitos Municipais e Supervisores da CNAE, para tratar de assuntos relativos ao Programa;

e) responsabilizar-se, nos termos da legislação em vigor, pela guarda, conservação, emprego e controle dos alimentos e/ou materiais que lhe forem confiados;

f) cumprir o Calendário aprovado para o Setor Regional;

g) apropriar o custeio operacional do Programa;

h) manter contatos com entidades nacionais e internacionais que cooperem para a eficiência do Programa, observadas as normas da CNAE e as instruções da Superintendência;

i) facilitar, aos órgãos competentes, os trabalhos de inspeção e auditoria;

j) designar seu substituto eventual;

1) visitar, periodicamente, os municípios sob sua jurisdição, para conhecimento das condições de execução do Programa e visando o seu aprimoramento.

Art. $5^{\circ}$ - À Equipe de Serviços do Setor Regional, constituída por empregados e/ou funcionários públicos, compete executar os serviços Técnicos e Administrativos do Setor Regional. 


\section{Serviços Técnicos:}
a) plano técnico de distribuição de alimentos;
b) educação alimentar;
c) preparação de alimentos e cardápio;
d) supervisão do programa;
e) cursos;
f) estatística;
g) hortas escolares e criação de pequenos animais;
h) criação e instalação de cantinas escolares;

\section{Serviços Administrativos:}
i) armazenamento;
j) material;
1) pessoal;
m)veículos;
n) dotações orçamentárias - suprimentos - contribuições;
o) administração em geral.

Art. $6^{\circ}$ - Compete, ainda, à Equipe de Serviços executar outros trabalhos, de acordo com a determinação da Chefia. 
A NEXO III

COMPOSIÇÃO DA MERENDA ESCOLAR POR DIVERSOS MOMENTOS DE SUA HISTÓRIA 


\section{COMPOSIÇÃO DA MERENDA ESCOLAR EM DIFERENTES PERÍODOS DA HISTÓRIA DO PROGRAMA*}

1) DÉCADA DE 40

COMPOSIÇÃO DO DESJEJUM ESCOLAR PROPOSTO POR DANTE COSTA (pg. 33)

\begin{tabular}{|l|c|c|c|c|c|}
\hline ALIMENTOS & GRAMAS & KCAL & $\begin{array}{c}\text { PROT: } \\
(\mathrm{g})\end{array}$ & $\begin{array}{c}\text { FE } \\
(\mathrm{mg})\end{array}$ & $\begin{array}{c}\text { VIT. C } \\
(\mathrm{mg})\end{array}$ \\
\hline PÄO FRANCÊS & 50 & 145 & 4,55 & 0,35 & -- \\
\hline AÇÚCAR & 15 & 58 & -- & 0,02 & -- \\
\hline LEITE & 200 & 99 & 8,32 & 0,10 & 1,90 \\
\hline MANTEIGA & 3 & 22 & 0,02 & 0,01 & -- \\
\hline SUCO DE LARANJA & 100 & 113 & 7,77 & 0,07 & -- \\
\hline QUEIJO & 40 & 45 & 0,70 & 0,20 & 50,00 \\
\hline TOTAI & & 481 & 19,7 & 0,74 & 51,90 \\
\hline
\end{tabular}

2) DÉCADA DE 50

\section{ALIMENTOS DO PROGRAMA DE MERENDA ESCOLAR:}

- LEITE (UNICEF E CCC)

- FARINHAS DE CEREAIS E LEGUMINOSAS ENRIQUECIDAS DE MINERAIS E VITAMINAS

3) DÉCADA DE 60

PRINCIPAIS ALIMENTOS QUE FIZERAM PARTE DO PROGRAMA DE MERENDA ESCOLAR EM DIFERENTES MOMENTOS DESSE PERÍODO:

- LEITE (UNICEF E CCC)

- TRIGO LAMINADO OU EM FARINHA

- FARINHA DE MILHO

- TRIGO BULGOR

- SOJA

- CSM (LEITE DESNATADO, SOJA E MILHO)

* Obs: Para a transformação das quantidades dos alimentos em nutrientes utilizou-se a Tabela de Composição de Alimentos do ENDEF (FUNDAÇÃO IBGE, 1985) e a Tabela de Composição Química dos Alimentos de Guilherme Franco (FRANCO, 1987). 
4) DÉCADAS DE 70 E 80

\section{PRODUTOS FORMULADOS}

\section{CARDÁPIO 1}

\begin{tabular}{|l|c|c|c|c|c|}
\hline \multicolumn{1}{|c|}{ ALIMENTOS } & GRAMAS & KCAL & $\begin{array}{c}\text { PROT } \\
(\mathrm{g})\end{array}$ & $\begin{array}{c}\text { FE } \\
(\mathrm{mg})\end{array}$ & $\begin{array}{c}\text { VIT. ( } \\
(\mathrm{mg})\end{array}$ \\
\hline MACARRÃO ENRIQUECIDO & 50 & 160 & 9,43 & 1,84 & -- \\
\hline CARNE MOÍDA & 64 & 128 & 12,16 & 2,01 & -- \\
\hline MOLHO DE TOMATE COM SOJA & 64 & 34 & 2,90 & 0,93 & 7,00 \\
\hline QUEIJO RALADO & 2 & 8 & 0,70 & -- & -- \\
\hline TOTAL & & 330 & 25,19 & 4,78 & 7,00 \\
\hline
\end{tabular}

\section{CARDÁPIO 2}

\begin{tabular}{|l|c|c|c|c|c}
\hline \multicolumn{1}{|c|}{ ALIMENTOS } & GRAMAS & KCAL & $\begin{array}{r}\text { PROT: } \\
(\mathrm{g})\end{array}$ & $\begin{array}{c}\text { FE } \\
(\mathrm{mg})\end{array}$ & $\begin{array}{c}\text { VTT. C } \\
(\mathrm{mg})\end{array}$ \\
\hline BOLACHA ENRIQUECIDA & 50 & 210 & 6,70 & 1,08 & - \\
\hline PASTA AMENDOIM & 25 & 150 & 5,00 & 0,38 & - \\
\hline LEITE & 25 & 125 & 6,60 & 0,10 & -- \\
\hline AÇÚCAR & 10 & 40 & -- & -- & - \\
\hline TOTAL & & 525 & 18,30 & 1,56 & - \\
\hline
\end{tabular}

CARDÁPIO 3

\begin{tabular}{|l|c|c|c|c|c|}
\hline \multicolumn{1}{|c|}{ ALIMENTOS } & GRAMAS & KCAL & $\begin{array}{c}\text { PROT: } \\
(\mathrm{g})\end{array}$ & $\begin{array}{c}\text { FE } \\
(\mathrm{mg})\end{array}$ & $\begin{array}{c}\text { VIT.C } \\
(\mathrm{mg})\end{array}$ \\
\hline POLENTA INSTANTÂNEA & 230 & 219 & 8,20 & 1,79 & -- \\
\hline CARNE MOÍDA & 95 & 192 & 18,24 & 3,02 & -- \\
\hline MOLHO DE TOMATE COM SOJA & 96 & 52 & 4,36 & 1,38 & 10,00 \\
\hline QUEIJO RALADO & 2 & 8 & 0,70 & -- & - \\
\hline TOTAL & & 471 & 31,50 & 6,19 & 10,00 \\
\hline
\end{tabular}


CARDÁPIO 4

\begin{tabular}{|l|c|c|c|c|c|}
\hline \multicolumn{1}{|c|}{ ALIIMENTOS } & GRAMAS & KCAL & $\begin{array}{c}\text { PROT: } \\
(\mathrm{g})\end{array}$ & $\begin{array}{c}\text { FE } \\
(\mathrm{mg})\end{array}$ & $\begin{array}{c}\text { VIT: C } \\
(\mathrm{mg})\end{array}$ \\
\hline CREME DE MANDIOQUINHA & 320 & 187 & 13,80 & 4,58 & 11,00 \\
\hline BANANADA & 75 & 282 & 10,20 & 0,45 & 130,00 \\
\hline TOTAL & & 469 & 24,00 & 5,03 & 141,00 \\
\hline
\end{tabular}

\section{CARDÁPIO 5}

\begin{tabular}{|l|c|c|c|c|c|}
\hline ATIMENTOS & GRAMAS & KCAL & $\begin{array}{c}\text { PROT. } \\
(\mathrm{g})\end{array}$ & $\begin{array}{c}\text { FE } \\
(\mathrm{mg})\end{array}$ & $\begin{array}{c}\text { VIT. C } \\
(\mathrm{mg})\end{array}$ \\
\hline PÃO ENRIQUECIDO & 75 & 280 & 10,50 & 1,70 & - \\
\hline PATÊ DE FÍGADO & 25 & 115 & 3,00 & 0,81 & - \\
\hline LEITE & 25 & 125 & 6,60 & 0,10 & - \\
\hline AÇÚCAR & 10 & 40 & -- & -- & - \\
\hline TOTAL & & 560 & 20,1 & 2,61 & - \\
\hline
\end{tabular}

\section{CARDÁPIO 6}

\begin{tabular}{|l|c|c|c|c|c|}
\hline ALIMENTOS & GRAMAS & KCAL & $\begin{array}{c}\text { PROT: } \\
(\mathrm{g})\end{array}$ & $\begin{array}{c}\text { FE } \\
(\mathrm{mg})\end{array}$ & $\begin{array}{c}\text { VIT. C } \\
(\mathrm{mg})\end{array}$ \\
\hline MACARRÃO COM CALDO DE FEIJÃO & 320 & 287 & 21,00 & 5,91 & 10,00 \\
\hline GOIABADA ENRIQUECIDA & 50 & 186 & 6,70 & 0,39 & 188,00 \\
\hline TOTAL & & 473 & 27,70 & 6,30 & 198,00 \\
\hline
\end{tabular}

\section{CARDÁPIO 7}

\begin{tabular}{|l|c|c|c|c|c|}
\hline ALIMENTOS & GRAMAS & KCAL & $\begin{array}{c}\text { PROT: } \\
(\mathrm{g})\end{array}$ & $\begin{array}{c}\text { FE } \\
(\mathrm{mg})\end{array}$ & $\begin{array}{c}\text { VIT. C } \\
(\mathrm{mg})\end{array}$ \\
\hline PÃO ENRIQUECIDO & 75 & 280 & 10,50 & 1,70 & -- \\
\hline PASTA AMENDOIM & 25 & 150 & 5,00 & 0,38 & -- \\
\hline LEITE & 25 & 125 & 6,60 & 0,10 & - \\
\hline AÇÚCAR & 10 & 40 & -- & -- & - \\
\hline TOTAL & & 595 & 22,10 & 2,18 & - \\
\hline
\end{tabular}


CARDÁPIO 8

\begin{tabular}{|l|c|c|c|c|c|}
\hline \multicolumn{1}{|c|}{ ALIMENTOS } & GRAMAS & KCAL & PROT. & $\begin{array}{c}\text { FE } \\
(\mathrm{mg})\end{array}$ & $\begin{array}{c}\text { VIT. C } \\
(\mathrm{mg})\end{array}$ \\
\hline CREME DE MILHO & 310 & 320 & 20,92 & 5,32 & 10,00 \\
\hline BANANADA & 50 & 188 & 6,80 & 0,30 & 87,00 \\
\hline TOTAL & & 508 & 27,72 & 5,62 & 97,00 \\
\hline
\end{tabular}

CARDÁPIO 9

\begin{tabular}{|l|c|c|c|c|c|}
\hline \multicolumn{1}{|c|}{ ALIMENTOS } & GRAMAS & KCAL & PROT. & $\begin{array}{c}\text { FE } \\
(\mathrm{m})\end{array}$ & $\begin{array}{c}\text { VIT. C } \\
(\mathrm{mg})\end{array}$ \\
\hline PÃO ENRIQUECIDO & 75 & 280 & 10,50 & 1,70 & - \\
\hline PATÊ DE PRESUNTO & 25 & 48 & 2,20 & 0,18 & - \\
\hline LEITE & 25 & 125 & 6,60 & 0,10 & -- \\
\hline AÇÚCAR & 10 & 40 & -- & -- & - \\
\hline TOTAL & & 493 & 19,30 & 1,98 & - \\
\hline
\end{tabular}

\section{CARDÁPIO 10}

\begin{tabular}{|l|c|c|c|c|c|}
\hline \multicolumn{1}{|c|}{ ALIMENTOS } & GRAMAS & KCAI & $\begin{array}{c}\text { PROT: } \\
(\mathrm{g})\end{array}$ & $\begin{array}{r}\text { FE } \\
(\mathrm{mg})\end{array}$ & $\begin{array}{c}\text { VIT. C } \\
(\mathrm{mg})\end{array}$ \\
\hline CREME DE CARÁ & 300 & 144 & 14,50 & 4,86 & 4,00 \\
\hline BANANADA & 50 & 188 & 6,80 & 0,30 & 87,00 \\
\hline TOTAL & & 332 & 21,30 & 5,16 & 91,00 \\
\hline
\end{tabular}


CARDÁPIO 11

\begin{tabular}{|l|c|c|c|c|c|}
\hline ALIMENTOS & GRAMAS & KCAL & $\begin{array}{c}\text { PROT. } \\
(\mathrm{g})\end{array}$ & $\begin{array}{c}\text { FE } \\
(\mathrm{mg})\end{array}$ & $\begin{array}{c}\text { VIT. C } \\
(\mathrm{mg})\end{array}$ \\
\hline BOLACHA ENRIQUECIDA & 50 & 210 & 6,70 & 1,08 & - \\
\hline PASTA AMENDOIM & 25 & 150 & 5,00 & 0,38 & - \\
\hline LEITE & 25 & 125 & 6,60 & 0,10 & -- \\
\hline AÇÚCAR & 10 & 40 & -- & -- & - \\
\hline CHOCOLATE & 5 & 25 & 0,50 & 0,33 & - \\
\hline TOTAL & & 550 & 18,80 & 1,89 & - \\
\hline
\end{tabular}

4b) CARDÁPIOS OFERECIDOS NAS ESCOLAS DA PREFEITURA MUNICIPAL DE SÃO PAULO (ROSENBURG, 1972)

CARDÁPIO 1

\begin{tabular}{|l|c|c|c|c|c|}
\hline ALTMENTOS & GRAMAS & KEAL & $\begin{array}{c}\text { PROT: } \\
(\mathrm{g})\end{array}$ & $\begin{array}{c}\text { FE } \\
(\mathrm{mg})\end{array}$ & $\begin{array}{c}\text { VT. C } \\
(\mathrm{mg})\end{array}$ \\
\hline PÄO FRANCÊS & 50 & 145 & 4,55 & 0,35 & -- \\
\hline AÇÚCAR & 14 & 54 & -- & 0,01 & -- \\
\hline LEITE EM PÓ & 20 & 99 & 5,26 & 0,09 & 1,73 \\
\hline CHOCOLATE & 10 & 40 & 0,80 & -- & -- \\
\hline MEL & 5 & 15 & 0,02 & 0,03 & 0,05 \\
\hline TOTAL & & 353 & 10,61 & 0,48 & 1,78 \\
\hline
\end{tabular}

CARDÁPIO 2

\begin{tabular}{|l|c|c|c|c|c|}
\hline ALIMENTOS & GRAMAS & KCAL & PROT: & $\begin{array}{c}\text { FE } \\
(\mathrm{g})\end{array}$ & $\begin{array}{c}\text { VIT. C } \\
(\mathrm{mg})\end{array}$ \\
\hline PÄO FRANCÊS & 50 & 145 & 4,55 & 0,35 & -- \\
\hline AÇÚCAR & 14 & 53 & -- & 0,01 & -- \\
\hline LEITE EM PÓ & 20 & 99 & 5,26 & 0,09 & 1,73 \\
\hline CHOCOLATE & 10 & 40 & 0,80 & -- & -- \\
\hline MARGARINA & 5 & 36 & 0,04 & -- & 0,01 \\
\hline TOTAL & & 374 & 10,65 & 0,45 & 1,74 \\
\hline
\end{tabular}


CARDÁPIO 3

\begin{tabular}{|l|c|c|c|c|c|}
\hline \multicolumn{1}{|c|}{ ALIMENTOS } & GRAMAS & KCAL & $\begin{array}{c}\text { PROT. } \\
(\mathrm{g})\end{array}$ & $\begin{array}{c}\text { FE } \\
(\mathrm{mg})\end{array}$ & $\begin{array}{c}\text { VIT. C } \\
(\mathrm{mg})\end{array}$ \\
\hline LEITE EM PÓ & 5 & 25 & 1,32 & 0,02 & 0,43 \\
\hline FUBÁ & 27,5 & 100 & 2,17 & 0,80 & -- \\
\hline ÓLEO DE SOJA & 5 & 44 & -- & -- & -- \\
\hline LEITE DESNATADO & 2,0 & 1 & 0,07 & -- & 0,02 \\
\hline TOTAL & & 170 & 3,56 & 0,82 & 0,45 \\
\hline
\end{tabular}

CARDÁPIO 4

\begin{tabular}{|l|c|c|c|c|c|}
\hline \multicolumn{1}{|c|}{ ALIMENTOS } & GRAMAS & KCAL & $\begin{array}{c}\text { PROT. } \\
(\mathrm{g})\end{array}$ & $\begin{array}{c}\text { FE } \\
(\mathrm{mg})\end{array}$ & $\begin{array}{c}\text { VIT. C } \\
(\mathrm{mg})\end{array}$ \\
\hline LEITE EM PÓ & 20 & 99 & 5,26 & 0,09 & 1,73 \\
\hline AÇÚCAR & 20 & 77 & -- & 0,02 & -- \\
\hline CANJICA & 60 & 60 & 1,32 & 0,12 & -- \\
\hline TOTALL & & 236 & 6,58 & 0,23 & 1,73 \\
\hline
\end{tabular}

4c) CARDÁPIO PROPOSTO NO CURSO DE SAÚDE ESCOLAR (CAVALCANTE, 1978, pg. 50))

\begin{tabular}{|l|c|c|c|c|c|}
\hline ALIMENTOS & GRAMAS & KCAL & PROT. & FE & VTT. C \\
\hline PÄO FRANCÊS & 50 & 145,00 & 4,55 & 0,35 & -- \\
\hline AÇÚCAR & 20 & 77,00 & -- & 0,02 & -- \\
\hline LEITE & 200 & 99,34 & 6,66 & 0,10 & 1,90 \\
\hline CHOCOLATE & 5 & 20,00 & 0,40 & -- & -- \\
\hline PATÊ DE FÍGADO & 15 & 30,15 & 2,02 & 1,38 & 1,46 \\
\hline BANANA & 60 & 55,20 & 0,62 & 0,19 & 5,46 \\
\hline TOTAL & & 426,69 & 14,25 & 2,03 & 8,82 \\
\hline
\end{tabular}




\section{A NEXO IV}

\section{COMPOSIÇÃO DOS CARDÁPIOS OFERECIDOS}

NO PROGRAMA DE MERENDA

ESCOLAR, NAS ESCOLAS PÚBLICAS DE SANTOS/SP, AGOSTO, 1996. 


\section{COMPOSIÇÃO DOS CARDÁPIOS OFERECIDOS NO PROGRAMA DE MERENDA}

ESCOLAR, NAS ESCOLAS PÚBLICAS DE SANTOS/SP, AGOSTO, 1996* .

\section{Semana}

\begin{tabular}{|c|c|c|c|c|c|c|c|c|}
\hline Dias & Alimentos" & $\begin{array}{l}\text { Qqtd } \\
\text { (g) }\end{array}$ & $\begin{array}{c}\text { Kca } \\
\mathrm{I}\end{array}$ & $\begin{array}{l}\text { Prot } \\
\text { (g) }\end{array}$ & $\begin{array}{l}\text { Ferro } \\
\text { (mg) }\end{array}$ & $\begin{array}{l}\text { ViTC } \\
\text { (mg) }\end{array}$ & $\begin{array}{c}\text { Retinol } \\
\text { (mcg) }\end{array}$ & $\begin{array}{c}C \\
\text { (m }\end{array}$ \\
\hline \multirow[t]{2}{*}{$\overline{2^{\mathbf{a}} \mathrm{f} .}$} & $\begin{array}{l}\text { risoto } \\
\text { ovo }\end{array}$ & $\begin{array}{l}60 \\
50\end{array}$ & $\begin{array}{c}219 \\
81\end{array}$ & $\begin{array}{l}4,3 \\
64\end{array}$ & $\begin{array}{l}0,8 \\
16\end{array}$ & - & $-\overline{-}$ & $\begin{array}{r}5 \\
31\end{array}$ \\
\hline & Total & & 300 & 10,7 & 2,4 & - & 265 & 36 \\
\hline \multirow[t]{7}{*}{$3^{a} f$} & arroz & 40 & 146 & 2,9 & 0,5 & - & - & $\overline{3}$ \\
\hline & feijão & 30 & 101 & 6,6 & 2,3 & 0,9 & - & 25 \\
\hline & lingüiça & 50 & 152 & 6,0 & 0,9 & - & - & 3 \\
\hline & $\begin{array}{l}\text { farofa: far. } \\
\text { mandioca }\end{array}$ & 20 & 69 & 0,3 & 0,2 & - & - & \\
\hline & ovo & 25 & 39 & 3,2 & 0,7 & 2,0 & 125 & 13 \\
\hline & óleo & & 63 & - & - & - & - & \\
\hline & Total & & 570 & 19,0 & 4,6 & 2,9 & 125 & 46 \\
\hline \multirow[t]{4}{*}{$4^{a} f$} & refresco tangerina & 200 & 84 & & & - & - & \\
\hline & pão & 50 & 134 & 4,7 & 0,6 & - & - & 11 \\
\hline & patê de frango & 10 & 41 & 1,0 & 0,4 & - & - & 2 \\
\hline & Total & & 259 & 6,1 & 1,3 & - & 10 & 18 \\
\hline \multirow[t]{4}{*}{$5^{\mathrm{a}} \mathrm{f}$} & macarrão & 70 & 247 & 9,8 & 1,3 & - & 15 & $\overline{16}$ \\
\hline & molho de carne & 50 & 90 & 3,3 & 0,6 & 1,30 & 29 & 11 \\
\hline & óleo & 2 & 18 & - & - & - & - & \\
\hline & Total & & 355 & $\overline{13,1}$ & 1,9 & 1,3 & $\overline{44}$ & 28 \\
\hline \multirow[t]{3}{*}{$6^{a} f$} & bebida láctea & 200 & 222 & 6,8 & - & - & - & \\
\hline & bolo & 60 & 174 & 5,1 & 0.6 & - & 41 & 19 \\
\hline & Total & & 396 & 11,9 & 0,6 & - & 41 & 19 \\
\hline
\end{tabular}

OBS: a) Utilizou-se as tabelas de Composiçăo de Alimentos do ENDEF (IBGE, 1985) eventualmente a de Guilherme Franco (1987)

b) Os cálculos foram arredondados para facilitar a interpretação.

- Obs.: Para a transformação das quantidades dos alimentos em nutrientes utilizou-se a Tabela de Composição de Alimentos do ENDEF (Fundação IBGE e a Tabela de Composição Química dos Alimentos de Guilherme Franco (FRANCO, 1987).

“. Dados fornecidos pela Seção de Nutrição da Secretaria Municipal de Santos/SP. 1996 
$2^{\text {a }}$ Semana

\begin{tabular}{|c|c|c|c|c|c|c|c|c|}
\hline Dias & Alimentos $^{1}$ & $\begin{array}{l}\text { Qqtd } \\
\text { (g) }\end{array}$ & $\begin{array}{c}\text { Kca } \\
1\end{array}$ & $\begin{array}{l}\text { Prot } \\
\text { (g) }\end{array}$ & $\begin{array}{l}\text { Ferro } \\
\text { (mg) }\end{array}$ & $\begin{array}{l}\text { ViTC } \\
\text { (mg) }\end{array}$ & $\begin{array}{r}\text { Retinol } \\
\text { (mcg) }\end{array}$ & $\begin{array}{l}\mathrm{Ca} \\
(\mathrm{mc}\end{array}$ \\
\hline \multirow[t]{2}{*}{$2^{a} f$} & $\begin{array}{l}\text { bebida láctea } \\
\text { biscoito de côco }\end{array}$ & $\begin{array}{c}200 \\
20\end{array}$ & $\begin{array}{c}260 \\
76\end{array}$ & $\begin{array}{l}7,1 \\
1,8\end{array}$ & $\begin{array}{c}0,4 \\
-\end{array}$ & - & $\begin{array}{c}282 \\
-\end{array}$ & $\begin{array}{r}227 \\
4\end{array}$ \\
\hline & Total & & 336 & 8,9 & 0,4 & - & 282 & $\overline{231,}$ \\
\hline \multirow[t]{7}{*}{$3^{a} f$} & purê de batata & 60 & 45 & 1,0 & 0,4 & 9,6 & $\overline{7}$ & 3 \\
\hline & leite & 20 & 12 & 0,7 & - & 0,3 & 7 & 24 \\
\hline & margarina & 5 & 36 & 0,02 & - & - & 46 & 1 \\
\hline & salsicha & 40 & 87 & 5,92 & 0,9 & - & 0 & 3 \\
\hline & molho & 20 & 23 & 1,06 & 0,5 & 1,3 & 32 & 11, \\
\hline & banana & 100 & 89 & 1,3 & 0,2 & 17,3 & 10 & 15 , \\
\hline & Total & & 292 & 10,0 & 2,0 & 28,5 & 95 & 59 , \\
\hline \multirow[t]{4}{*}{$4^{\mathrm{a}} \mathrm{f}$} & refresco de & 200 & 84 & 0,6 & 1,0 & 14,0 & - & 70 \\
\hline & & 50 & 135 & 4,7 & 0,6 & - & - & 11, \\
\hline & margarina & 10 & 72 & - & - & - & 92 & 2 \\
\hline & Total & & 291 & 4,7 & 0,6 & 2,1 & 92 & $\overline{14}$ \\
\hline \multirow[t]{7}{*}{$5^{a} f$} & arroz & 40 & 146 & 2,9 & 0,5 & 0 & - & 3 \\
\hline & feijão & 30 & 101 & 6,6 & 2,3 & 0,9 & 1 & 25 , \\
\hline & frango & 50 & 53 & 9,9 & 1,0 & - & 5 & 1 \\
\hline & legumes - batata & 20 & 15 & 0,4 & 1,2 & - & - & 3 , \\
\hline & - cenoura & 20 & 8 & 0,2 & 0,1 & 1,6 & 220 & 7 , \\
\hline & óleo & 5 & 45 & - & - & - & - & - \\
\hline & Total & & 368 & 19,9 & 5,1 & 2,5 & 226 & 40 , \\
\hline \multirow[t]{6}{*}{$6^{a} \mathrm{f}}$. & $\begin{array}{l}\text { bebida láctea } \\
\text { leite pó }\end{array}$ & & 100 & 5,3 & - & - & 54 & $\overline{181,}$ \\
\hline & açúcar & 10 & 40 & - & - & - & - & - \\
\hline & Chocolate & 5 & 95 & 0,5 & 0,3 & - & 3 & 4, \\
\hline & pão doce & 50 & 137 & 3,8 & 0,6 & - & - & 6 \\
\hline & doce de leite & 40 & 116 & 3,5 & 0,1 & 0,4 & 3,2 & 70 \\
\hline & Total & & 452 & 13,1 & 1,0 & 0,4 & 60,2 & $\overline{261,}$ \\
\hline
\end{tabular}

OBS: a) Utilizou-se as tabelas de Composição de Alimentos do ENDEF (IBGE, 1985) eventualmente a de Guilherme Franco (1987)

b) Os cálculos foram arredondados para facilitar a interpretação.

${ }^{1}$ Dados fornecidos pela Seção de Nutrição da Secretaria Municipal de Santos/SP. 1996. 


\section{3a Semana}

\begin{tabular}{|c|c|c|c|c|c|c|c|c|}
\hline Dias & Alimentos $^{2}$ & $\begin{array}{l}\text { Qqtd } \\
\text { (g) }\end{array}$ & $\begin{array}{c}\text { Kca } \\
\text { I }\end{array}$ & $\begin{array}{l}\text { Prot } \\
\text { (g) }\end{array}$ & $\begin{array}{l}\text { Ferro } \\
\text { (mg) }\end{array}$ & $\begin{array}{l}\text { ViTC } \\
\text { (mg) }\end{array}$ & $\begin{array}{c}\text { Retinol } \\
\text { (mcg) }\end{array}$ & $\begin{array}{c}\mathrm{Ca} \\
(\mathrm{mg})\end{array}$ \\
\hline \multirow[t]{6}{*}{$2^{a} f$} & arroz & 40 & 146 & 2,9 & 0,5 & 0 & 0 & 3,6 \\
\hline & lentilha & 30 & 102 & 7,1 & 2,1 & 1,5 & 1 & 20,4 \\
\hline & frango & 60 & 74 & 13,2 & 0,8 & - & 15,0 & 72,0 \\
\hline & ovo & 50 & 82 & 6,4 & 1,6 & - & 265 & 30,0 \\
\hline & óleo & 5 & 45 & - & - & - & - & - \\
\hline & Total & & 449 & 29,6 & 5,0 & 1,5 & 281 & 126,0 \\
\hline \multirow[t]{4}{*}{$3^{a} f$} & macarrão & 70 & 247 & 9,8 & 1,33 & - & 15 & 16,8 \\
\hline & carne refogada & 60 & - & - & - & - & - & - \\
\hline & óleo & 5 & 45 & - & - & - & - & - \\
\hline & Total & & & & & & & \\
\hline \multirow[t]{4}{*}{$4^{a} f$} & refresco guaraná & 10 & 40 & - & - & - & - & - \\
\hline & pão & 50 & 134 & 4,6 & 0,6 & - & - & 11,0 \\
\hline & patê de presunto & 10 & 41 & 1,0 & 0,4 & - & - & 2,7 \\
\hline & Total & & 215 & 5,6 & 1,0 & - & - & 13,7 \\
\hline \multirow[t]{7}{*}{$5^{a} f$} & arroz & 40 & 146 & 2,9 & 0,5 & - & - & 3,6 \\
\hline & feijão & 30 & 10 & 6,6 & 2,3 & 0,9 & 0,6 & 25,8 \\
\hline & carne seca & 30 & 132 & 12,6 & 2,9 & - & - & 9,0 \\
\hline & $\begin{array}{l}\text { farofa - far. } \\
\text { Mandioca }\end{array}$ & 20 & 69 & 0,3 & 0,2 & 2,0 & - & 9,0 \\
\hline & ovo & 25 & 39 & 3,2 & 0,7 & - & 125,0 & 13,5 \\
\hline & óleo & 7 & 63 & - & - & - & - & - \\
\hline & Total & & 459 & 25,6 & 6,6 & 2,9 & 125,6 & - \\
\hline \multirow[t]{3}{*}{$6^{a} \mathrm{f}}$. & bebida láctea & 200 & 218 & 7,0 & 3,9 & 1,59 & 208 & 248,5 \\
\hline & bolo & 60 & 174 & 5,1 & 0,6 & - & 41 & 19,0 \\
\hline & Total & & 392 & 12,1 & 4,5 & 1,59 & 249 & - \\
\hline
\end{tabular}

OBS: a) Utilizou-se as tabelas de Composiçăo de Alimentos do ENDEF (IBEG, 1985) eventualmente a de Guilherme Franco (1987)

b) Os cálculos foram arredondados para facilitar a interpretaçăo.

\footnotetext{
${ }^{2}$ Dados fornecidos pela Seção de Nutrição da Secretaria Municipal de Santos/SP. 1996.
} 


\begin{tabular}{|c|c|c|c|c|c|c|c|c|}
\hline Dias & Alimentos $^{3}$ & $\begin{array}{l}\text { Qqtd } \\
\text { (g) }\end{array}$ & $\begin{array}{c}\text { Kca } \\
1\end{array}$ & $\begin{array}{l}\text { Prot } \\
\text { (g) }\end{array}$ & $\begin{array}{l}\text { Ferro } \\
\text { (mg) }\end{array}$ & $\begin{array}{l}\text { ViTC } \\
\text { (mg) }\end{array}$ & $\begin{array}{c}\text { Retinol } \\
\text { (mcg) }\end{array}$ & $\begin{array}{c}\mathrm{Ca} \\
(\mathrm{mg})\end{array}$ \\
\hline \multirow[t]{3}{*}{$2^{a} f$} & risoto & 60 & 219 & 4,3 & 0,8 & - & - & 5,0 \\
\hline & ovo & 50 & 81 & 6,4 & 1,6 & - & 265 & 31,0 \\
\hline & Total & & 300 & 10,7 & 2,4 & - & 265 & 36,0 \\
\hline \multirow[t]{8}{*}{$3^{a} f$} & purê de batata & 60 & 45 & 1,0 & 0,4 & 0,6 & - & 3,6 \\
\hline & leite & 20 & 12 & 0,7 & - & 0,3 & 7 & 24,6 \\
\hline & margarina & 5 & 36 & - & - & - & 46 & 1,0 \\
\hline & frango & 60 & 74 & 13,2 & 0,8 & - & 15 & 1,2 \\
\hline & molho (lata) & 20 & 23 & 1,1 & 0,5 & 1,3 & 32 & 11,2 \\
\hline & óleo & 5 & 45 & - & - & - & - & - \\
\hline & banana & 100 & 89 & 1,3 & 0,2 & 17,3 & 10 & 15,0 \\
\hline & Total & & 324 & 17,3 & 1,9 & 19,5 & 110 & 41,6 \\
\hline \multirow[t]{4}{*}{$4^{a} f$} & refresco tangerina & 200 & 84 & - & - & - & - & - \\
\hline & pão & 50 & 134 & 4,7 & 0,6 & - & - & 11,0 \\
\hline & salsicha & 40 & 87 & 5,9 & 0,9 & - & - & 3,6 \\
\hline & Total & & 305 & 10,6 & 1,5 & - & - & 14,6 \\
\hline \multirow[t]{7}{*}{$5^{a} f$} & arroz & 40 & 146 & 2,9 & 0,5 & - & - & 3,6 \\
\hline & feijão & 30 & 101 & 6,6 & 2,3 & 0,9 & 1,0 & 25,8 \\
\hline & carne moída & 60 & 67 & 12,6 & 1,9 & - & 1,0 & 12,0 \\
\hline & legumes - cenoura & 20 & 8 & 0,2 & 0,1 & 1,6 & 220 & 7,4 \\
\hline & batata & 20 & 15 & 0,4 & 1,2 & - & - & 3,0 \\
\hline & óleo & 7 & 63 & - & - & - & - & - \\
\hline & Total & & 400 & 22,7 & 6,0 & 2,5 & 222 & 51,8 \\
\hline \multirow[t]{5}{*}{$6^{\mathrm{a}} \mathrm{f}$} & $\begin{array}{l}\text { bebida láctea - } \\
\text { leite pó }\end{array}$ & 20 & 100 & 5,3 & - & - & 54 & 181,0 \\
\hline & - açúcar & 10 & 40 & - & - & - & - & - \\
\hline & chocolate & 5 & 95 & 0,5 & 0,3 & - & 3 & 4,0 \\
\hline & pão doce & 50 & 137 & 3,8 & 0,6 & - & - & 6,0 \\
\hline & Total & & 372 & 9,6 & 0,9 & - & 57 & 191,0 \\
\hline
\end{tabular}

OBS: a) Utilizou-se as tabelas de Composição de Alimentos do ENDEF (IBGE, 1985) eventualmente a de Guilherme Franco (1987)

b) Os cálc3ulos foram arredondados para facilitar a interpretação.

\footnotetext{
${ }^{3}$ Dados fornecidos pela Seção de Nutrição da Secretaria Municipal de Santos/SP. 1996.
} 
A NEXOV

SIGLAS UTILIZADAS NO TEXTO E SEUS SIGNIFICADOS 


\section{SIGLAS UTILIZADAS NO TEXTO}

ABIA Associação Brasileira das Industrias de Alimentação

AID Agency for Inernational Develpment

CCC Commodit Credit Corporation

CEPAL Comissão Econômica para América Latina e Caribe

CNA Comissão Nacional de Alimentação

CNME Companhia Nacional da Merenda Escolar

$\mathrm{CNPq}$ Conselho Nacional de Desenvolvimento Científico e Tecnológico

COBAL Companhia Brasileiro de Alimentação

COMEB Caracterização Operacional de Merenda Escolar Brasileira

CSM "Corn, Soy and Milk" - Farinha Distribuida pela USAID

DAE Departamento de Alimentação Escolar

ENDEF Estudo Nacional de Despesa Familiar

FAE Fundação de Assistência ao Estudante

FAO Organização das Nações Unidas para a Agricultura e Alimentação/Food and Agriculture Organization

IBEG Instituto Brasileiro de Geografia e Estatística

INACG International Nutrional Anemia Consultative Group

INAE Instituto Nacional de Alimentação Escolar

INAN Instituto Nacional de Alimentação e Nutrição

INCAP Instituto de Nutricíon de Centro Americay Panama

MEC Ministério da Educação e Cultura

NCHS National Center for Health Statistics 
NDpCal\% Expressa a Porcentagem de Calorias Derivadas das Proteínas, Corrigidas pela Eficiência da Utilização das Proteínas (NPU)

NPR Quociente de Utilização Real de Proteína

NPU Net Protein Utilization-Nitrogênio Retido/Nitrogênio ingerido

OMS Organização Mundial de Saúde

ONU Organização das Nações Unidas

OPS Organização Panamericana de Saúde

PER Quociente de Eficiência Proteíca

PIB Produto Interno Bruto

PINA Programa Integrado de Nutrição Aplicada

PNAE Programa Nacional de Alimentação Escolar

. PNSN Pesquisa Nacional de Saúde e Nutrição

PRONAN Programa Nacional de Alimentação e Nutrição

SAPS Serviço de Alimentação de Previdência Social

SES Secretaria de Estado da Educação

UNICEF Fundo Internacional de Socorro a Infância das Nações Unidas/United Nations International Children Emergency Fund United

USAID Uited States Agency for International Development

VCT Valor Calórico Total

UNU Universidade das Nações Unidas 